\title{
4. COMPOSITION AND BIOSTRATIGRAPHY OF RADIOLARIAN ASSEMBLAGES FROM AN AREA OF UPWELLING (NORTHWESTERN ARABIAN SEA, LEG 117)1
}

\author{
Catherine Nigrini ${ }^{2}$
}

\begin{abstract}
Significant numbers of radiolarians ranging in age from late middle Miocene to Recent were recovered from six sites drilled on the Oman margin and Owen Ridge. Sparse faunas were recovered from five additional sites on the Oman margin and one site on the Indus Fan. Detailed range charts and biozonations are presented for most sites. The radiolarian assemblages are peculiar in that numerous common tropical forms, some of which are biomarkers, are absent or very rare. In addition, some species not usually found in tropical assemblages are present. These forms, indicative of upwelling conditions, fall into three categories: (1) endemic upwelling: species endemic to upwelling and not previously described from the Indian Ocean; (2) displaced temperate: temperate forms not usually found in tropical waters; and (3) enhanced tropical: tropical forms which are more abundant and/or robust in areas of upwelling. Comparison of the Oman margin/Owen Ridge fauna with that recovered from the Peru margin upwelling area (ODP Leg 112) suggests that the assemblage may be globally diagnostic of upwelling conditions.

The onset of upwelling is marked by the appearance of siliceous biota at about $11.9 \mathrm{Ma}$, and there is some indication of a decrease in the strength of the upwelling signal at about 9.6 Ma. A strong pulse in, or strengthening of, the upwelling mechanism is indicated by a marked fauna change at $4.7 \mathrm{Ma}$. There is a weaker signal, implying a change in upwelling conditions, at about $1.5 \mathrm{Ma}$.
\end{abstract}

\section{INTRODUCTION}

Significant numbers of radiolarians were recovered in $6(721$, $722,723,728,730$, and 731) of the 12 sites occupied during Leg 117 of the Ocean Drilling Project. A sparse fauna was recovered from five $(720,724,725,726$, and 727$)$ additional sites, and one site (729) is completely barren of siliceous microfossils. One site (720) is located on the Indus Fan and the remaining sites are on the Owen Ridge and Oman margin. The locations (Fig. 1) and water depths of these sites are as follows:

\begin{tabular}{lllrl} 
Site & \multicolumn{2}{c}{ Location } & $\begin{array}{c}\text { Water } \\
\text { depth } \\
(\mathrm{m})\end{array}$ & $\begin{array}{c}\text { Physical } \\
\text { setting }\end{array}$ \\
\hline 720 & $16^{\circ} 07.796^{\prime} \mathrm{N}$ & $60^{\circ} 44.210^{\prime} \mathrm{E}$ & 4037.5 & Indus Fan \\
721 & $16^{\circ} 40.636^{\prime} \mathrm{N}$ & $59^{\circ} 51.799^{\prime} \mathrm{E}$ & 1944.8 & Owen Ridge \\
722 & $16^{\circ} 37.312^{\prime} \mathrm{N}$ & $59^{\circ} 47.755^{\prime} \mathrm{E}$ & 2027.8 & Owen Ridge \\
723 & $18^{\circ} 03.079^{\prime} \mathrm{N}$ & $57^{\circ} 36.561^{\prime} \mathrm{E}$ & 807.8 & Oman margin \\
724 & $18^{\circ} 27.713^{\prime} \mathrm{N}$ & $57^{\circ} 47.147^{\prime} \mathrm{E}$ & 592.8 & Oman margin \\
725 & $18^{\circ} 29.200^{\prime} \mathrm{N}$ & $57^{\circ} 42.030^{\prime} \mathrm{E}$ & 311.5 & Oman margin \\
726 & $17^{\circ} 48.945^{\prime} \mathrm{N}$ & $57^{\circ} 22.290^{\prime} \mathrm{E}$ & 330.8 & Oman margin \\
727 & $17^{\circ} 46.096^{\prime} \mathrm{N}$ & $57^{\circ} 35.216^{\prime} \mathrm{E}$ & 914.5 & Oman margin \\
728 & $17^{\circ} 40.790^{\prime} \mathrm{N}$ & $57^{\circ} 49.553^{\prime} \mathrm{E}$ & 1427.5 & Oman margin \\
729 & $17^{\circ} 38.715^{\prime} \mathrm{N}$ & $57^{\circ} 57.221^{\prime} \mathrm{E}$ & 1398.5 & Oman margin \\
730 & $17^{\circ} 43.885^{\prime} \mathrm{N}$ & $57^{\circ} 41.519^{\prime} \mathrm{E}$ & 1065.5 & Oman margin \\
731 & $16^{\circ} 28.229^{\prime} \mathrm{N}$ & $59^{\circ} 42.149^{\prime} \mathrm{E}$ & 2365.5 & Owen Ridge
\end{tabular}

The radiolarian zones used in this paper are those of Nigrini (1971) and Riedel and Sanfilippo (1978). The recently proposed zonation for the tropical Indian Ocean of Johnson et al. (1989) was not used partly because some of the marker species are missing, and partly to correspond with the site reports (Prell, Niitsuma, et al., 1989). There are also some difficulties in applying the established tropical zonations because of the absence

\footnotetext{
${ }^{1}$ Prell, W. J., Niitsuma, N., et al., 1991. Proc. ODP, Sci. Results, 117: College Station, TX (Ocean Drilling Program).

2510 Papyrus Drive, La Habra Heights, CA 90631, U.S.A.
}

or rarity of traditional biomarkers such as $P$. prismatium and $S$. pentas.

On the other hand, a number of species, some of which have not been previously observed in Indian Ocean sediments, and which are not usually found in tropical sediments, have been recorded. Some of these forms are known from sediments deposited under Peruvian and East Pacific upwelling currents (Nigrini, 1968), while others are abundant in temperate areas, such as the Crozet Basin, and are very rare in tropical populations. These species will be discussed further in the section entitled "Upwelling Assemblage."

\section{METHODS}

Although the upper portions of most of the sites were double- or tripled-cored using the Hydraulic Piston Corer, only a single composite section for each site is reported herein. Within the intervals where radiolarians were found to be well preserved, two samples per core, usually from Section 4 and the corecatcher, were prepared and examined. Sample preparation followed the standard techniques described by Sanfilippo et al. (1985). Samples were sieved at $63 \mu \mathrm{m}$ and two strewn slides prepared per sample.

For each sample examined, qualitative estimates of radiolarian abundance $(\mathrm{C}=$ common; $\mathrm{F}=$ few; $\mathrm{R}=$ rare; $-=\mathrm{ab}-$ sent) and preservation ( $\mathrm{G}=$ good; $\mathrm{M}=$ moderate; $\mathrm{P}=$ poor) were made. Range charts based on presence or absence $(\mathrm{P}=$ present; $+=$ one or two specimens; $-=$ absent; ? = dubious identification) of stratigraphically important species were constructed for each site or interval containing significant numbers of radiolarians (Appendix A, Tables 1-9). In addition, several species which seem to be endemic to, or whose distribution is controlled by, upwelling have been described and new data concerning their stratigraphic ranges are presented (Appendix A, Tables 10-12). Overall radiolarian occurrence is summarized in Figure 2. Appendix B contains taxonomic notes pertaining to the species examined.

\section{RADIOLARIANS AT EACH SITE}

A summary of the radiolarian findings at each site is given in this section. Raw data for each site are presented in Appendix A 


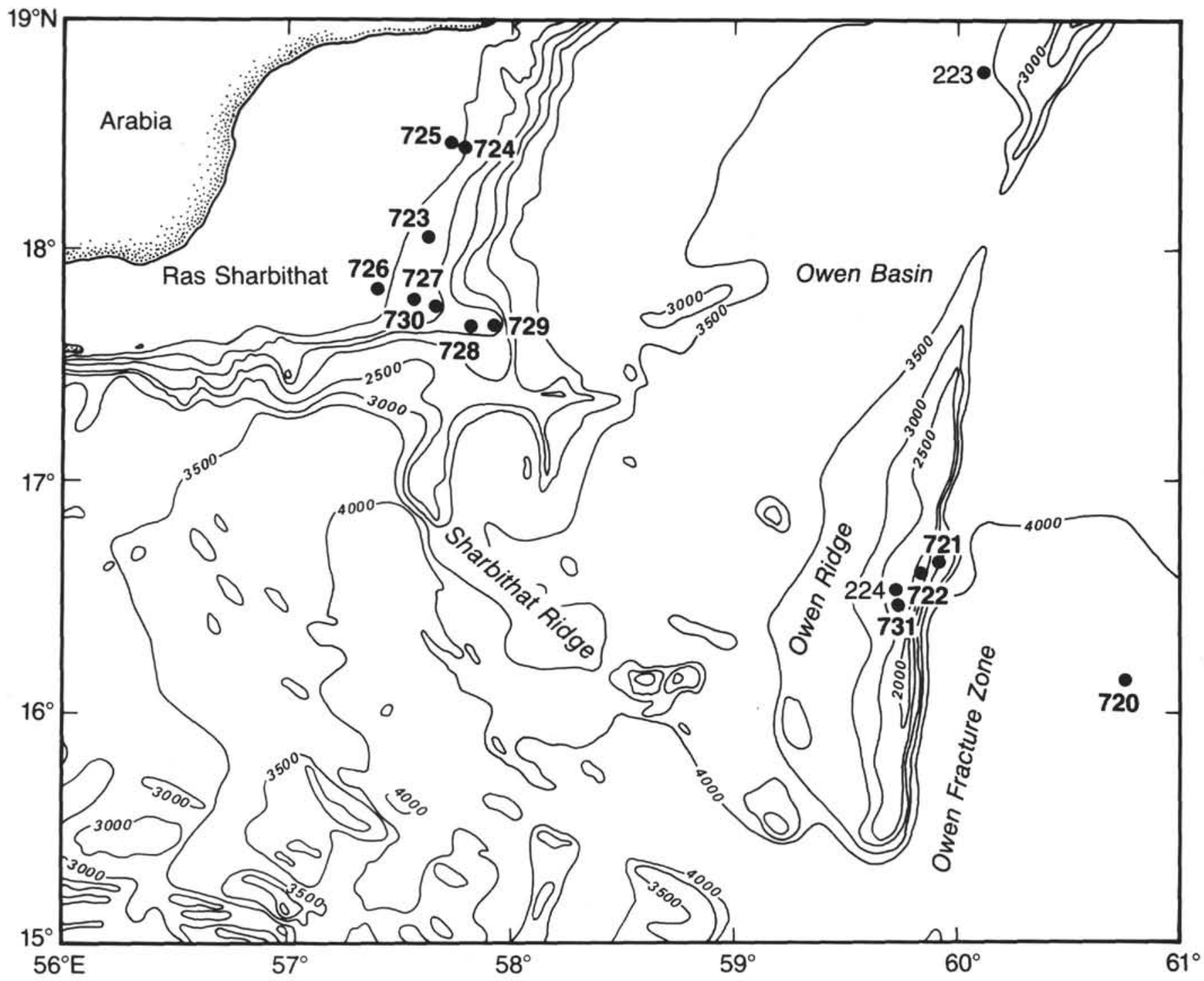

Figure 1. Simplified bathymetric map (contours in meters) of the Leg 117 operations area and location of ODP and DSDP drill sites.

(Tables 1-9) for those intervals containing well preserved assemblages. Using these range charts, a list of radiolarian "events" (first and last morphotypic appearances) was constructed for each of the most prolific sites (Appendix A, Tables 13-17). A comparison of the order of these events is presented in Appen$\operatorname{dix}$ A, Table 18 .

\section{Site 720 (Hole 720A)}

Site 720, a single hole drilled on the westernmost part of the middle Indus Fan, consists of a short pelagic sequence underlain by a long series of generally unfossiliferous turbidites interrupted by short pelagic sequences. Radiolarians were found in Cores 117-720A-1H through 117-720A-3H (0-28.6 mbsf), in Sample 117-720A-17X-CC (164.0 mbsf) and in Core 117-720A-30X (279.8-289.4 mbsf). In the upper sequence, radiolarians are generally rare and show signs of dissolution; both abundance and preservation decline with depth and there is considerable masking by terrigenous material. The fauna consists mainly of Spumellaria, and age-diagnostic forms are sparse. Pterocorys hertwigii and Lamprocyrtis nigriniae were found in Sample 117-720A$1 \mathrm{H}-\mathrm{CC}(9.35 \mathrm{mbsf})$, thus placing the sample in the upper Pleistocene.
A sparse, moderately well preserved fauna was found in Sample 117-720A-17X-CC (164.0 mbsf), but age diagnostic taxa are lacking. Single specimens of Eucyrtidium acuminatum and Pterocanium praetextum eucolpum suggest a cool-water fauna.

The most robust and diverse radiolarian fauna found at this site occurred within two samples from pelagic layers within Core 117-720A-30X (117-720A-30X-2, 80-82 cm, and -30X-4, 74-76 $\mathrm{cm}, 282.1$ and $285.0 \mathrm{mbsf}$, respectively). This fauna also suggests a cool-water fauna with very robust specimens of Lamprocyrtis neoheteroporos and Eucyrtidium calvertense. A single specimen of Anthocyrtidium angulare places Sample 117-720A$30 \mathrm{X}-4,74-76 \mathrm{~cm}(285.0 \mathrm{mbsf})$, in the $A$. angulare Zone (Nigrini, 1971), while the presence of $L$. neoheteroporos means that the sample is older than $1.1 \mathrm{Ma}$, but younger than $1.5 \mathrm{Ma}$ (Johnson et al., 1989).

\section{Site 721 (Holes 721A, B, C)}

Site 721 is located on the top of the Owen Ridge in the western Arabian Sea. Three holes were drilled to provide a composite section down to the lower Miocene. Radiolarians are abundant, robust, and well preserved in almost all samples examined down to 117-721B-32X-CC (308.4 mbsf). From 117-721B-33X- 
RADIOLARIAN ASSEMBLAGES FROM UPWELLING AREA

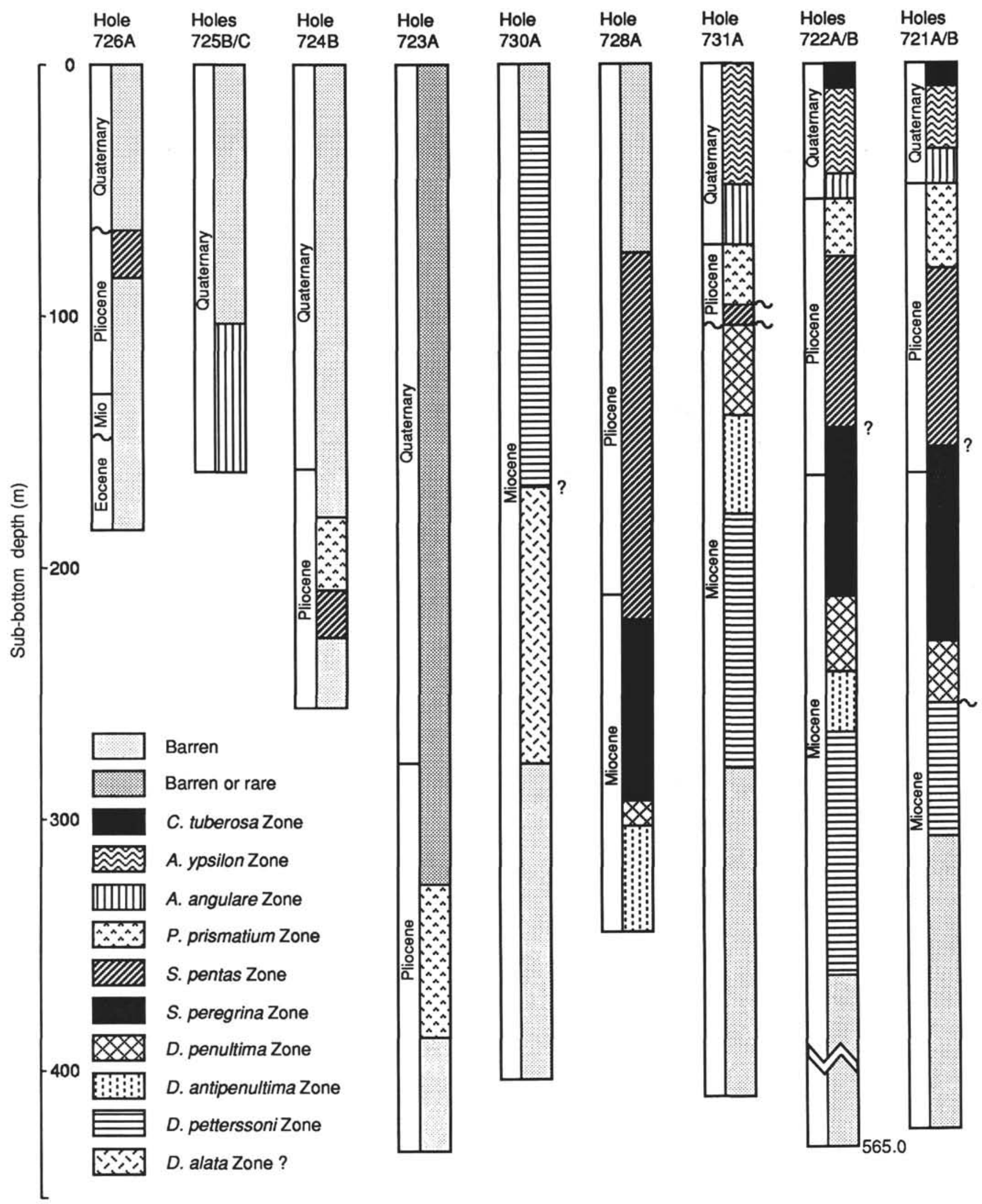

Figure 2. Summary chart of radiolarian zonation for ODP Leg 117, Sites 721-731, except for Sites 727 and 729 which are barren of radiolarians. 
CC (318.00 mbsf), to $117-721 \mathrm{~B}-44 \mathrm{X}-\mathrm{CC}$ (424.2 mbsf), radiolarians are virtually absent. Most samples below 117-721 A-7H-CC (67.3 mbsf), contain some reworked middle Miocene taxa. Diatoms are noticeable in Sample 117-721B-13X-CC (124.4 mbsf), and gradually increase in abundance downhole until they become quite abundant in Sample 117-721B-23X-CC (221.3 mbsf). Hole 721A and the lower part of Hole 721B formed the composite section examined for radiolarians (Appendix A, Tables 1, 10 , and 13).

Sample $117-721 \mathrm{~A}-1 \mathrm{H}-\mathrm{CC}$ (9.4 mbsf), probably belongs to the Collosphaera tuberosa Zone. It was not possible to determine a zone for Samples 117-721A-2H-CC (19.5 mbsf), to 117 $721 \mathrm{~A}-4 \mathrm{H}-4,85-87 \mathrm{~cm}(34.55 \mathrm{mbsf})$, due to the scarcity or absence of age-diagnostic taxa. Samples 117-721A-4H-CC (38.9 mbsf), through 117-721A-5H-CC (48.5 mbsf), belong to the $A n$ thocyrtidium angulare Zone. Sample 117-721A-6H-4, $85-87 \mathrm{~cm}$ (53.85 mbsf), marks the top of the Pterocanium prismatium Zone, but this determination is based on only two specimens in the sample. A similar virtual absence of this species was noted by Nigrini (1974) at DSDP Site 223. Sample 117-721A-9H-CC (86.4 mbsf), belongs to the Spongaster pentas Zone.

Sample 117-721B-10X-4, 85-87 cm (91.35 mbsf), also belongs to the Spongaster pentas Zone and the zone persists through Sample 117-721B-16X-CC (153.5 mbsf). Samples 117-721B-17X-4, $85-87 \mathrm{~cm}$ (158.85 mbsf), through 117 721B-24X-CC (230.5 mbsf), lie within the Stichocorys peregrina Zone. Since only single specimens of Spongaster pentas were observed sporadically and Spongaster berminghami is virtually absent, the zonal boundary was approximated to the last appearance of Solenosphaera omnitubus. The transition from Stichocorys delmontensis to Stichocorys peregrina, marking the top of the Didymocyrtis penultima Zone, occurs between Samples 117-721B-24X-CC (230.5 mbsf), and 117-721B-25X-4, 85-87 cm (235.85 mbsf). However, considerable reworking of $S$. delmontensis may have influenced the placement of this zonal boundary. Between Samples 117721B-27X-4, 85-87 cm (255.15 mbsf), and 117-721B-27X-CC (259.6 mbsf), there is an hiatus, and the Didymocyrtis antepenultima Zone is entirely missing. The Diartus petterssoni Zone continues through Sample 117-721B-32X-CC (308.4 mbsf). The rest of the recovered material is virtually barren of radiolarians.

\section{Site 722 (Holes 722A, B)}

Site 722 was drilled on the Owen Ridge in the western Arabian Sea. Radiolarians recovered are abundant, robust, and well preserved throughout Hole $722 \mathrm{~A}$ and in material down to Sample 117-722B-37X-CC (353.1 mbsf), in Hole 722B. Sample 117722B-38X-CC (362.8 mbsf), contains a few radiolarians most of which are coated with pyrite. The remainder of Hole 722B is barren of radiolarians. See Appendix A, Tables 2, 11, and 14 for detailed range charts. The uppermost Quaternary radiolarian zone, the Buccinosphaera invaginata Zone, is missing and Sample $117-722 \mathrm{~A}-1 \mathrm{H}-\mathrm{CC}$ ( $9.8 \mathrm{mbs})$, probably belongs to the Collosphaera tuberosa Zone. Samples 117-722A-2H-4, $85-87 \mathrm{~cm}$ ( 15.15 mbsf), through 117-722A-5H-4, $85-87 \mathrm{~cm}$ (43.95 mbsf), belong to the Amphirhopalum ypsilon Zone, while Samples $117-722 \mathrm{~A}-5 \mathrm{H}-\mathrm{CC}$, through $117-722 \mathrm{~A}-6 \mathrm{H}-4,85-87 \mathrm{~cm}(48.2-$ $53.55 \mathrm{mbsf}$ ), are in the Anthocyrtidium angulare Zone. The top of the Pterocanium prismatium Zone has been placed at Sample $117-722 \mathrm{~A}-6 \mathrm{H}-\mathrm{CC}$ (57.5 mbsf), but this is based on the presence of only two specimens of $P$. prismatium, which is very rare in this part of the Indian Ocean. The zone is present through Sample 117-722A-8H-CC (76.8 mbsf). Sample 117-722A-9H-CC (86.5), contains the last common occurrence of Stichocorys peregrina and marks the top of the Spongaster pentas Zone, although a few reworked specimens were found above this level. The lower limit of the $S$. pentas Zone is impossible to locate ac- curately, because it is based on the evolutionary transition of Spongaster berminghami to Spongaster pentas; the latter species is absent or extremely rare in this area. Therefore, the $S$. pentas/S. peregrina zonal boundary has been approximated to the last occurrence of Solenosphaera omnitubus in Sample 117722A-16X-CC (154.3 mbsf). The lower limit of the $S$. peregrina Zone is also difficult to determine accurately because that boundary is defined by the evolutionary transition of Stichocorys delmontensis to $S$. peregrina, and the samples contain considerable reworking of the ancestral species, as well as various Miocene species of Didymocyrtis and Diartus. The boundary between the $S$. peregrina and Didymocyrtis penultima Zones has been placed, with some misgivings, between Samples 117-722A-22X$\mathrm{CC}$, and $117-722 \mathrm{~A}-23 \mathrm{X}-4,85-87 \mathrm{~cm}(212.4-217.75 \mathrm{mbsf})$. The top of the Didymocyrtis antepenultima Zone is defined by the last occurrence of Diartus hughesi in Sample 117-722A-26X-CC (251.0 mbsf), although reworking of $D$. hughesi presents some difficulties in defining the boundary. At this level diatoms also become quite common.

To form a composite section, analysis of Hole 722B began with Sample 117-722B-28X-CC, which is assigned to the $D$. antepenultima Zone; the zone continues through Sample 117-722B30X-CC (265.9-285.3 mbsf). The remainder of the cored interval lies within the Diartus petterssoni Zone. However, reworking again makes it difficult to locate a boundary which is dependent upon an evolutionary transition $(D$. petterssoni to $D$. hughesi in this case). Diatoms are abundant between Samples 117-722B$31 \mathrm{X}-\mathrm{CC}$, and 117-722B-37X-CC (295.0-353.1 mbsf). The siliceous fauna in Sample 117-722B-37X-CC (353.1 mbsf), is robust and diverse, but in Sample 117-722B-38X-CC (362.8 mbsf), the fauna is much reduced and more than half the radiolarians have been pyritized; diatoms are absent.

\section{Site 723 (Holes 723A, B, C)}

Site 723 is located at the deep seaward end-point of a depth transect drilled on the continental margin of Oman. The transect was designed to correspond to the vertical extent of a pronounced oxygen minimum zone. Three holes were occupied, but only Hole 723A was examined for radiolarians. Radiolarian abundances vary from barren to common with peak abundances ("common") in Samples 117-723A-5H-CC (46.4 mbsf), 117723A-33X-CC, through 117-723A-37X-CC (316.7-345.4 mbsf), 117-723A-41X-CC (384.0 mbsf), and 117-723A-42X-CC (393.6 mbsf). See Appendix A, Table 3. Material below Sample 117$723 \mathrm{~A}-35 \mathrm{X}-\mathrm{CC}$, belongs to the $P$. prismatium Zone. In general, diatom abundances are in concert with radiolarian abundances. Considerable detrital material was found in all processed samples. Low radiolarian abundances could, therefore, reflect low standing crops or masking by detritus or a combination of both conditions.

All the usual tropical Pleistocene and upper Pliocene zonal markers are absent. All elements of the Lamprocyrtis heteroporos to Lamprocyrtis nigriniae lineage are present, but their sporadic occurrences in this material provided unreliable datum levels.

The criteria described by Johnson and Nigrini (1980) for a modern Arabian Upwelling Assemblage were tested on the uppermost sample containing common radiolarians, i.e., 117-723A$5 \mathrm{H}-\mathrm{CC}$. This assemblage is dependent upon the presence of their Recurrent Group D' (Collosphaera sp. aff. C. huxleyi, Lamprocyclas maritalis ventricosa, and Lamprocyrtis nigriniae) and the absence of a majority of species belonging to their tropical Recurrent Group A' . Sample 117-723A-5H-CC, does contain the Arabian Upwelling Assemblage. In addition, two species (Lithostrobus sp. cf. L. hexagonalis and Acrosphaera murrayana) associated with the Peru Current upwelling (Nigrini, 
1968), but not included in Johnson and Nigrini's (1980) study, are consistently present in Hole 723A. See section on "Upwelling Assemblage."

\section{Site 724 (Holes 724A, B, C)}

Site 724 is at the central point of a depth transect located on the continental margin of Oman. Core-catcher samples from Hole 724B were examined for radiolarians. The upper 19 cores (to $180.4 \mathrm{mbsf}$ ) are either barren or have a very sparse fauna (45 specimens per strewn slide). Diatoms are also absent from these samples.

Samples 117-724B-20X-CC, to 117-724B-24X-CC (190.0-228.7 mbsf) contain a significant number of robust radiolarians, but species diversity is low. Stylosphaerids and Artostrobiidae dominate the assemblages. The LAD of Stichocorys peregrina occurs in Sample 117-724B-22X-CC (209.4 mbsf), and marks the upper limit of the Spongaster pentas Zone. This species is the only tropical zonal marker found in Hole 724B. Radiolarian abundances decrease again in Samples 117-724B-26X-CC, and 117-724B-27X-CC (248.0 and 257.7 mbsf). See Appendix A, Table 4 .

\section{Site 725 (Holes 725A, B, C)}

Site 725 is the shallow landward end-point of a depth transect located on the continental margin of Oman. Samples 117$725 \mathrm{~B}-1 \mathrm{H}-\mathrm{CC}$ to $117-725 \mathrm{~B}-10 \mathrm{X}-\mathrm{CC}$ (7.5-93.8 mbsf), and 117725C-11X-CC, to 117-725C-17X-CC (104.9-162.8 mbsf), which together form a continuous sequence, were examined for radiolarians. The upper 10 cores are barren. However, samples examined below that level have a significant radiolarian fauna along with diatoms and sponge spicules. The presence of Anthocyrtidium angulare in Samples 117-725C-12X-CC (114.5 mbsf), and 117-725C-14X-CC (133.8 mbsf), places these samples, at least, in the Anthocyrtidium angulare Zone. The occurrence of Lamprocyrtis neoheteroporos in Samples 117-725C-16X-CC (153.2 mbsf), and $117-725 \mathrm{C}-17 \mathrm{X}-\mathrm{CC}$ (162.8 mbsf), suggests that these samples probably lie within the $A$. angulare Zone as well. The fauna at this site (Appendix A, Table 5) is more diverse than that at Site 724 , although there is still a paucity of tropical zonal marker species. Numerous specimens of Dictyophimus infabricatus, first described from the eastern equatorial Pacific and indicative of upwelling conditions, were found, along with $A$. murrayana and Collosphaera sp. aff. C. huxleyi.

\section{Site 726 (Hole 726A)}

Site 726 is located on the Oman continental margin. Radiolarians are absent from most of the sedimentary sequence recovered at Site 726, except for the interval between Samples 117726A-8X-2, 85-87 cm, and 117-726A-9X-CC (65.9-82.8 mbsf). In these sediments there is a good, well preserved radiolarian fauna belonging to the Spongaster pentas Zone, but species diversity is low. Sponge spicules and diatoms are also common in this interval. See Appendix A, Table 6.

\section{Site 727 (Holes 727A, B)}

Site 727 is located on the continental margin of Oman near the center of a pronounced oxygen minimum zone. Most of the recovered material at Site 727 is barren of radiolarians. Rare, non-age-diagnostic fragments were found in Samples 117-727A15X-CC (143.6 mbsf), and 117-727A-17X-CC, through -19XCC (163.0-182.4 mbsf).

\section{Site 728 (Holes 728A, B)}

Site 728 was drilled on the continental margin of Oman near the center of a slope basin. The core-catcher samples of Cores $117-728 \mathrm{~A}-1 \mathrm{H}$ through $117-728 \mathrm{~A}-4 \mathrm{H}$ (9.6-38.0 mbsf) are barren of radiolarians. Between Cores $117-728 \mathrm{~A}-5 \mathrm{H}$ and $117-728 \mathrm{~A}-8 \mathrm{H}$
(47.5-76.1 mbsf) a few radiolarian fragments are found in the core-catcher samples. However, radiolarians are common and well preserved from Sample 117-728A-9H-CC, to Sample 117728A-36X-CC (85.7-346.4 mbsf). The top of this siliceous sequence coincides with a pronounced spike in clay content as shown by downhole logging, and a change in porosity as shown by the physical properties measurements. The radiolarians are generally mixed with varying quantities of mineral fragments, sponge spicules, and diatoms. Samples 117-728A-9H-CC, through 117-728A-23X-CC (85.7-220.8 mbsf), are in the Spongaster pentas Zone. Since $S$. pentas and $S$. berminghami are virtually absent, the $S$. pentas/Stichocorys peregrina zonal boundary has been approximated to the LAD of Solenosphaera omnitubus. The $S$. peregrina Zone extends from $117-728 \mathrm{~A}-24 \mathrm{X}-4,85-87 \mathrm{~cm}$, to $117-728 \mathrm{~A}-31 \mathrm{X}-4,82-84 \mathrm{~cm}$ (226.15-293.82 mbsf). Samples 117-728A-31X-CC, and 117-728A-32X-4, 85-87 cm (298.1$303.45 \mathrm{mbsf}$ ), lie within the Didymocyrtis penultima Zone and Samples 117-728A-32X-CC, to 117-728A-36X-CC (307.8-336.8 mbsf), lie within the Didymocyrtis antepenultima Zone. See Appendix A, Tables 7 and 12. Hole 728B was not examined for radiolarians.

\section{Site 729 (Hole 729A)}

This site, located on the continental margin of Oman, is barren of siliceous microfossils.

\section{Site 730 (Hole 730A)}

Site 730 is situated on the Oman margin near the bottom of a pronounced oxygen minimum zone which impinges on the margin. Radiolarians are common and well preserved in Samples $117-730 \mathrm{~A}-4 \mathrm{H}-4,85-87 \mathrm{~cm}$, through $117-730 \mathrm{~A}-20 \mathrm{X}, 85-87 \mathrm{~cm}$ (37.65-191.2 mbsf). They decrease in abundance, and preservation is only moderate between Samples 117-730A-21X-4, 85-87 $\mathrm{cm}$, and 117-730A-24X-CC (196.55-229.9 mbsf). From Sample 117-730-25X-CC, to Sample 117-730A-29X-CC (239.6-278.2 mbsf), there is a further decrease in abundance and deterioration in preservation state. Both above and below these intervals the recovered sediments are barren of siliceous microfossils. Diatoms and sponge spicules are common to abundant throughout the silica-rich interval. Sponge spicules are particularly robust, but show some pitting due to dissolution in the sections where radiolarians are less abundant.

From Sample 117-730A-4H-4, 85-87 cm, to Sample 117-730A$18 \mathrm{X}-4,85-87 \mathrm{~cm}$ (32.65-167.55 mbsf), the radiolarians belong to the Diartus petterssoni Zone. The FAD of $D$. petterssoni is in Sample $117-730 \mathrm{~A}-18 \mathrm{X}-4,85-87 \mathrm{~cm}$, and this event normally marks the $D$. petterssoni/Dorcadospyris alata zonal boundary. Thus, the sediments from Sample 117-730A-18X-CC, to Sample 117-730A-25X-CC (171.9-239.6 mbsf), appear to belong to the D. alata Zone. However, the LAD of Liriospyris parkerae and D. alata should also coincide approximately with this boundary and neither of those species was observed. In addition, placement of the $D$. petterssoni/D. alata boundary between Samples $117-730 \mathrm{~A}-18 \mathrm{X}-4,85-87 \mathrm{~cm}$, and 117-730A-18X-CC (167.55-171.9 mbsf), is inconsistent with the nannofossil zonal data. Material below Sample 117-730A-25X-CC, is too poorly preserved to allow for a zonal determination. See Appendix A, Tables 8 and 13.

\section{Site 731 (Holes 731A, B, C)}

Site 731 is located in the western Arabian Sea on the Owen Ridge. In Hole 731A all core-catcher samples from Cores 117731A-1H through 117-731A-29X (9.8-279.9 mbsf) contain radiolarians. Below this level all core-catcher samples are barren. Diatoms are a common component of the siliceous fauna between Samples 117-731A-16X-CC (149.9 mbsf), and 117-731A27X-CC (260.6 mbsf). No siliceous microfossils occur in any of the material recovered at Holes $731 \mathrm{~B}$ or $731 \mathrm{C}$. 
Samples 117-731A-1H-CC (9.8 mbsf), and 117-2H-CC (19.3 mbsf), contain a few, moderately well preserved radiolarians which appear to belong to the Amphirhopalum ypsilon Zone. Both preservation and abundance improve in Sample 117-731A$3 \mathrm{H}-\mathrm{CC}$ (28.8 mbsf), and remain relatively good through Sample 117-731A-20X-CC (192.8 mbsf). The A. ypsilon/Anthocyrtidium angulare zonal boundary lies between Samples 117-731A-5H$\mathrm{CC}$ (47.8 mbsf) and 117-731A-6H-4, 85-87 cm (53.15 mbsf). Presumably Sample 117-731A-7H-CC (67.0 mbsf) lies within the $A$. angulare Zone, but the nominate species is absent. Based, alas, on a single fragment of Pterocanium prismatium, Sample 117-731A-8X-CC (76.7 mbsf), has been placed in the $P$. prismatium Zone. A hiatus probably occurs within Core 117-731A-11X, because Sample 117-731A-11X-4, 85-87 cm, belongs to the lower part of the Spongaster pentas Zone; Lychnodictyum audax, Phormostichoartus fistula, and Phormostichoartus doliolum are all present. Another hiatus lies within Core 117-731A-12X, and the Stichocorys peregrina Zone is entirely missing. Sample 117-731A-12X-CC (115.4 mbsf), lies within the Didymocyrtis penultima Zone which continues through Sample 117-731A-15X-4, $85-87 \mathrm{~cm}$ (140.05 mbsf). The LAD of Diartus hughesi in Sample 117-731A-15X-CC (144.4 mbsf), denotes the top of the Didymocyrtis antepenultima Zone and its transition from Diartus petterssoni between Samples 117-731A-18X-CC (173.4 mbsf), and 117-731A-19X-CC (183.1 mbsf), marks the boundary with the $D$. petterssoni Zone. The remainder of the radiolarian-bearing sediment apparently belongs to this zone. Below Sample 117731A-21X-CC (202.5 mbsf), there is a general decrease in radiolarian abundance and preservation; Samples 117-731A-28X-CC (270.2 mbsf), and 117-731A-29X-CC (279.9 mbsf), contain only rare radiolarians and many of those in the latter sample have been pyritized. See Appendix A, Tables 9, 12, and 17.

\section{COMPARISON OF RADIOLARIAN EVENTS}

Careful comparison of the order in which radiolarian events (morphotypic first and last occurrences) occur in Sites 721, 722, 728,730 , and 731 (Table 1) allows for a number of interesting observations. The order of events is much more stable in the upper part of the stratigraphic column (most crossed correlation lines are due to single sample discrepancies) and becomes increasingly mixed with depth. There are two reasons for this: (1) the paleomagnetically derived ages in the last 4-4.5 Ma are more reliable because they have been measured directly from piston cores (Johnson et al., 1989); and (2) events that have been found in previous studies to be unreliable have been eliminated.

Events that are part of an evolutionary transition such as the $D$. antepenultima $\rightarrow D$. penultima, D. pettersson $\rightarrow D$. hughesi, and $S$. delmontensis $\rightarrow S$. peregrina sequences are generally unreliable because of problems in identification. Other unreliable events of this type are the last occurrences of $P$. marylandicus and $D$. laticonus.

Events, such as the first and last appearances of $A$. tritubus and $S$. ambus, that involve rare, albeit distinctive, forms are often not reliable. In the Indian Ocean the forms involved in the $S$. berminghami $\rightarrow S$. pentas lineage are also too rare to be useful.

Finally, although $B$. bramlettei is relatively easy to recognize, its last occurrence seems to be quite erratic. This observation was also made by Nigrini (1985) in the Central Pacific.

Previous studies (Johnson and Nigrini, 1985; Baker, 1983) have shown that the first occurrence of Theocorythium trachelium is diachronous by about $1 \mathrm{Ma}$ between the Pacific Ocean (1.5-1.6 m.y.) and the central Indian Ocean (2.4-2.5 m.y. in DSDP Site 214). However, in the present study the age of its first occurrence seems to be more closely allied to that found in the Pacific Ocean. Similarly, the age for the last occurrence of
D. bursa is more in line with that found in the western Pacific (6.1-6.3 m.y). than that reported at DSDP Site 214 (5.0-5.1 m.y.).

The present study allows us, at least, to bracket some ages for certain events. In the study area the first occurrence of $T$. trachelium is between 1.09 and $1.56 \mathrm{~m} . \mathrm{y}$. and the last occurrence of $D$. bursa is between 6.2 and $6.5 \mathrm{~m}$.y. The last occurrence of D. splendens lies between 3.83 and $4.8 \mathrm{~m}$.y., but this span can be further reduced by considering the data of Johnson et al. (1989) in which the form was not found in central Indian Ocean piston cores which reached a maximum age of $4.4 \mathrm{Ma}$. Therefore, the last occurrence of $D$. splendens probably lies between 4.4 and $4.8 \mathrm{~m}$.y. The first occurrence of $S$. ambus lies between 5.7 and $6.6 \mathrm{~m} . \mathrm{y}$.

\section{UPWELLING ASSEMBLAGE}

A number of species related to upwelling conditions were first described by Nigrini (1968) from the area of the Peru Current. Since then, there have been several, more sophisticated, studies in the same area related to the definition of "upwelling assemblages" (Molina-Cruz, 1977, 1984; Schramm, 1984; Romine and Moore, 1981). Each of these authors used Q-mode factor analysis to define various radiolarian assemblages, both in sediment surface samples and downcore (Quaternary), in the eastern Equatorial and Subtropical Pacific. Qualitative inspection of their data shows that the following species appear to be important components of the upwelling assemblage off the Peruvian coast: Acrosphaera murrayana, Dictyophimus infabricatus, Pterocorys minythorax, and Cycladophora davisiana (all of which are also considered herein); Botryostrobus auritus/australis (which probably included Botryostrobus bramlettei tumidulus and $B$. bramlettei pretumidulus, both of which are considered herein); Spongurus sp. and Cenosphaera(?) sp., which are poorly defined counting groups, Lithelius minor, and a counting group comprised of Tetrapyle octacantha and Octopyle stenozona (none of which are considered herein). The $\mathrm{Te}$ trapyle octacantha-Octopyle stenozona group is common throughout the tropics (Lombari and Boden, 1985) and it is necessary to make detailed counts in order to establish its increased abundance in areas of upwelling.

The present study of the upwelling fauna found in the Arabian Sea and qualitative comparison with the assemblages recovered from the Peru margin during ODP Leg 112 (J. P. Caulet, pers. comm., 1988) suggest that species which constitute an upwelling assemblage fall into three categories (see Table 2):

1. Endemic upwelling: species which are endemic to upwelling;

2. Displaced temperate: forms which are abundant in middle latitudes, but which can be found in tropical areas influenced by upwelling; and

3. Enhanced tropical: forms found in tropical sediments, but which are more abundant and/or more robust in areas of upwelling.

\section{ENDEMIC UPWELLING SPECIES}

\section{Species Present in Sediments from both the Oman and Peru Margins}

Cypassis irregularis is common in sediments from the Peru margin and the coastal basins of California (Nigrini, 1968; Kling, 1977). It is a Quaternary form and ODP Leg 112 studies (De Wever et al., in press) suggest that it is restricted to the last $0.4 \mathrm{Ma}$. It is rare in the Oman material, but was reported by Johnson and Nigrini (1980) as part of their Arabian Margin Upwelling Assemblage. 
Dictyophimus infabricatus is common and well-developed in sediments from the Peru margin, whereas it is generally rare and poorly developed in most of the material recovered from the Oman margin. It is well represented only at Site 725 in several samples within the $A$. angulare Zone and at Site 731 in the $A$. ypsilon Zone. It has not been previously reported from the Indian Ocean. In the Peru material it was found that the FAD of $D$. infabricatus occurs just below the LAD of $A$. nosicaae (1.11.4 m.y. in the Central Pacific).

Lamprocyclas maritalis ventricosa was first recognized by Nigrini (1968) in the eastern tropical Pacific. It occurs, but not as abundantly, in the Oman margin sediments. Its earliest occurrence is in the P. prismatium Zone at both Site 722 and Site 731. The subspecies was not considered by De Wever et al. (in press) for Leg 112 , and more precise taxonomy is probably required before one can delineate its range and abundance. It is possible, also, that this subspecies is not really an endemic upwelling form, but a larger, more robust variation of the tropical nominate subspecies.

\section{Species Present in Sediments from the Oman Margin Only}

Collosphaera sp. aff. C. huxleyi was first recognized and described by Johnson and Nigrini (1980) in core top samples, and was considered by them to be an important component of their Arabian margin recurrent group. Downcore examination of the stratigraphic range of this species has revealed an interesting distribution. Its first appearance is not recorded in the present material, i.e., it is older than about $11.9 \mathrm{Ma}$. It is common throughout the $D$. penultima Zone, gradually decreases in abundance and size, and finally disappears near the top of the $S$. peregrina Zone. It appears again, however, at the base of the $A$. angulare Zone and is common in all younger material.

Eucyrtidium sp. (Pl. 1, figs. 1 and 2) is never common, but is a distinctive form which ranges from the base of the $S$. pentas Zone to the middle of the $P$. prismatium Zone. It is characterized by small pores and an unusually long third segment relative to the lengths of the other segments.

Anthocyrtidium sp. (Pl. 1, fig. 4) is a rare, short ranging, but distinctive form with widely spaced, straight terminal teeth. It was never observed by Nigrini and Caulet (1988) in their extensive revision of tropical species belonging to the genus Anthocyrtidium. The species ranges from the top of the $S$. peregrina Zone to the top of the $S$. pentas Zone.

Actinomma spp. group (Pl. 1, figs. 5-7) consists of forms having a large (265-355 $\mu \mathrm{m})$, heavy cortical shell with a rough surface and six or more three-bladed spines originating on the medullary shell. The spines may be crenulated distally and, in some specimens, one spine is noticeably longer than the others. There is usually a single medullary shell, although, rarely, an inner medullary has been observed. The pores of the cortical shell are spherical to subspherical and may be regularly or irregularly arranged. The forms included in this species group are larger and heavier shelled than Actinomma haysi and lack the characteristic cortical bi-spines. Members of this species group are a distinctive component of the material recovered from the Oman margin and Owen Ridge from the $D$. penultima Zone to the $A$. ypsilon Zone, but increase markedly in abundance above the base of the $S$. pentas Zone ( 4.7 Ma).

\section{Species Present in Sediments from the Peru Margin Only}

Plectacantha cremastoplegma and Pterocanium grandiporus were both described by Nigrini (1968). Pseudocubus warreni was described by Goll (1980). See De Wever et al. (in press) for further discussion of these forms.

\section{DISPLACED MIDDLE LATITUDE SPECIES FOUND IN TROPICAL AREAS WHICH ARE INFLUENCED BY UPWELLING}

\section{Species Present in Sediments from the Oman and Peru Margins}

Acrosphaera murrayana group is composed of three species described by Goll (1980), A. murrayana, A. cyrtodon, and $A$. trepanata. Although there may be some merit to the distinctions made by Goll, the present author was unable to apply consistently his criteria for differentiating between the species, particularly with respect to the recognition of $A$. trepanata. In addition, observations during this study suggest that the relationship between $A$. cyrtodon and Collosphaera sp. aff. C. huxleyi needs to be considered in conjunction with this group of species. The A. murrayana group is common for a brief period during the time of the $D$. petterssoni Zone, and then is greatly reduced in numbers or absent until the beginning of the $S$. pentas Zone when it becomes common and is consistently present to the Recent. In the Leg 112 material these three species were considered separately and only presence-absence data were recorded; their ranges are not consistent with those reported by Goll (1980). Nigrini (1968) found $[P$.] murrayana to be "abundant to few in the regions of the North and South Equatorial and Peru Currents, but rare or absent in the region of the Equatorial Countercurrent." One is tempted to consider this species group to be endemic to upwelling, but it has been found in some abundance in the Crozet Basin (J. P. Caulet, pers. comm., 1988).

Eucyrtidium calvertense (Pl. 1, fig. 3) has been described by numerous authors (Martin, 1904; Hays, 1965; Kellogg, 1976), but always from middle and high latitude sediments. In the Oman margin sediments, it is consistently present throughout the $S$. peregrina and $S$. pentas Zones and rare, possibly reworked, specimens can be found in the Pleistocene. In samples from the Peru margin the species is consistently present throughout the Pleistocene.

Eucyrtidium teuscheri group and Eucyrtidium teuscheri teuscheri were first described in detail by Caulet (1986) from high (DSDP Site 594) and low (DSDP Site 586B) latitude sediments recovered during DSDP Leg 90 . However, E. teuscheri was first described by Haeckel (1887) from the central equatorial Pacific and later by Petrushevskaya (1967) from south and north of the Antarctic convergence. It is abundant in the temperate population of the Crozet Basin (J. P. Caulet, pers. comm., 1988). In the Oman material $E$. teuscheri group is consistently present from the $D$. petterssoni Zone to midway through the $S$. pentas Zone where it evolves into $E$. teuscheri teuscheri. This is consistent with the distribution found in the Peru margin material. $E$. teuscheri orthoporus was only rarely observed.

Botryostrobus bramlettei pretumidulus was first described by Caulet (1979) and Botryostrobus bramlettei tumidulus was first described by Bailey (1856), but the descriptions are brief and further clarification of the distinction between them is needed. $B$. b. tumidulus is characterized by the conical outline of the first four segments and a relatively large fourth segment. The fifth and subsequent segments are narrower and more or less cylindrical. On the other hand, it is the first five segments of $B . b$. pretumidulus that form a cone and the segments increase uniformly in size. The sixth and subsequent segments are narrower and more or less cylindrical. Caulet $(1979$, fig. 4) suggested that $B$. b. tumidulus evolves from $B . b$. pretumidulus between 2 and $3 \mathrm{~m}$.y. ago and that $B$. b. pretumidulus eyolves from $B$. bramlettei between 5 and $7 \mathrm{~m}$.y. ago. The data herein suggests that the relationship between these forms is more complex. In Sites $\mathbf{7 2 1}$ and $722, B$. b. pretumidulus first appears at about $4.7 \mathrm{Ma}$, but 
Table 1. Comparison of radiolarian events at Sites 721, 722, 728, 730, and 731. Bracketed events occur between the same sample pair. Dashed lines indicate tentative or extrapolated correlations.

Epoch Zone Age(my) Radiolarian Event

Site 722

Site 721

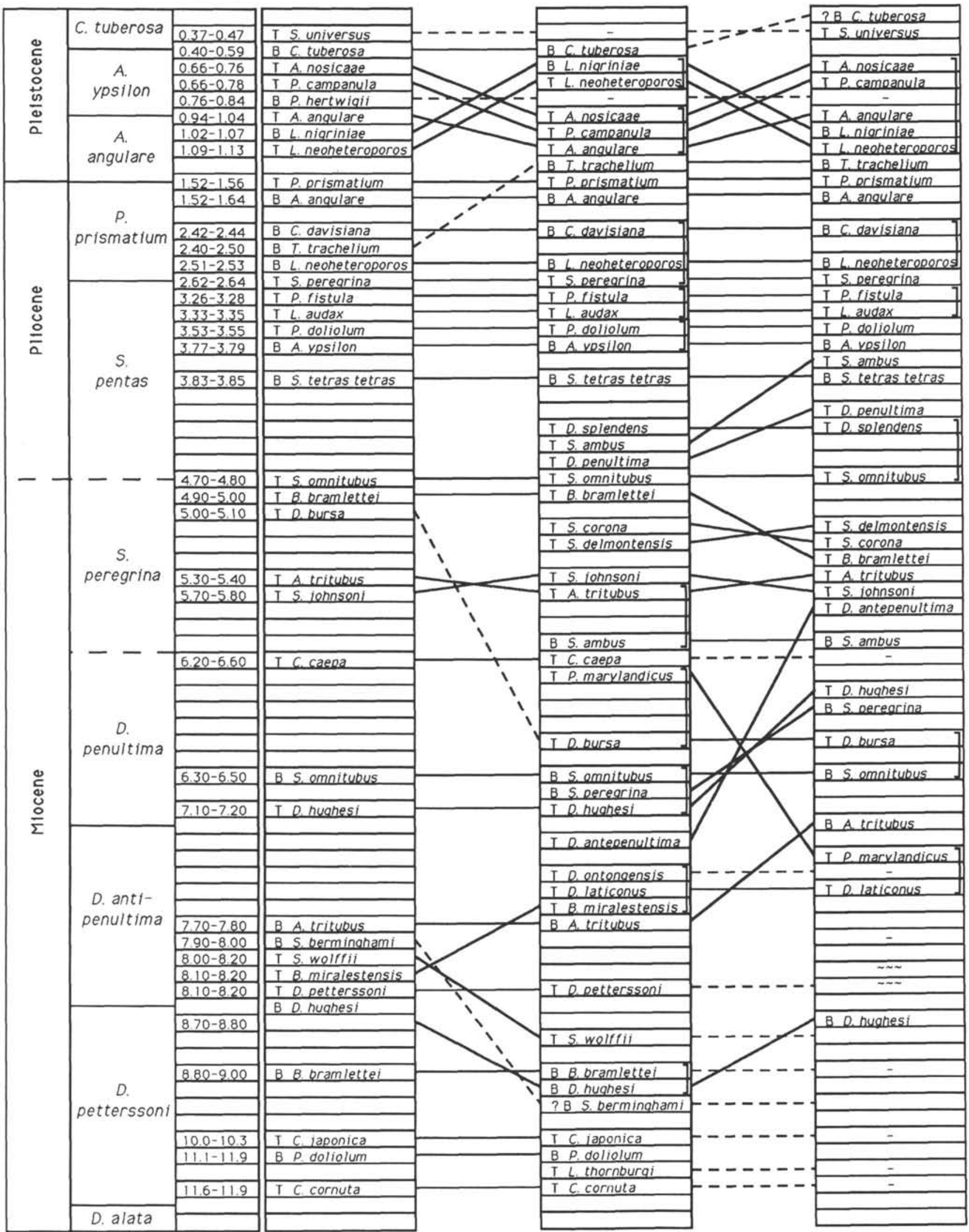


Table 1 (continued).

Site 721

? B C tuberesa I s.universus

I A nosicare

I P campanula

I A. anqulare

B L nioriniae

I L neoheteroperes

B I. trachelium

I Perismatium

B A anqulare

B C. davisiana

B L neoheteropores

I s. perearina

$T$ P fistula

T L audax

B A rpsilion

I $S$ ambus

B S. tetras tetras

$T$ D penultima

I $\mathrm{Q}$. splendens

I s. omnitubus

\begin{tabular}{|l|}
\hline \\
\hline T S delmontensis \\
\hline T S. corona \\
\hline
\end{tabular}

T B. bramlettei

\begin{tabular}{ll} 
I A. tritubus \\
\hline T S. iohnsoni
\end{tabular}

T D. antepenultima

B S ambus

T $D$. huahesi

B S eerearina

I e bursa

B 5 emnitubus

\begin{tabular}{|l}
\hline \\
\hline B A. rritubus \\
\hline
\end{tabular}

I P marvlandicus

\begin{tabular}{|c}
- \\
\hline I 0 laticenus
\end{tabular}

\begin{tabular}{|c|}
\hline$I$ Q laticenus \\
\hline \\
\hline- \\
\hline \\
\hline$\sim \sim \sim$ \\
\hline$\sim \sim \sim$
\end{tabular}

\begin{tabular}{|l}
\hline B R huahesi \\
\hline
\end{tabular}

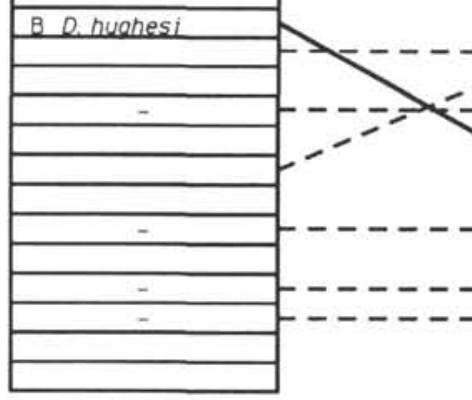

$A$

-

-
Site 731

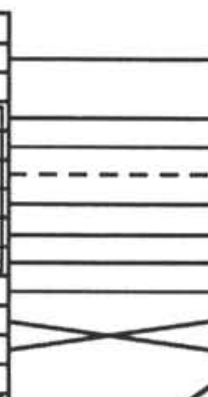

I s universus

I A nesicaae

I P camoanula

B $P$ hertwioii

I A anoulare

B L niariniae

I h neoheteroporos

B I trachelium

B A anqulare

I P.erismatium

I P fistula

B C davisiana 7

B L neohetereoeres

I S eerearina

I L a audax

I $P$ deliolum

B A rosilen

I $S$ ambus

B S.tetras tetras I S. berminghami

I l eenultima

I $\mathrm{l}$ solendens

\section{S emnitubus}

I S. delmentensis

I S. corena

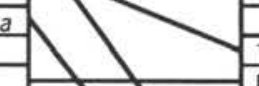

- \begin{tabular}{l} 
B S S ambus \\
\hline L c caepa
\end{tabular}

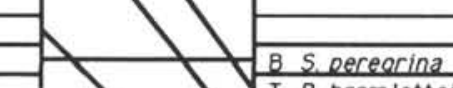

T B. bramlette

I D. bursa

T D antepenultima

B S.emnitubus

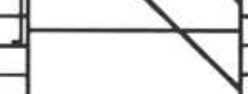

I D huahesi
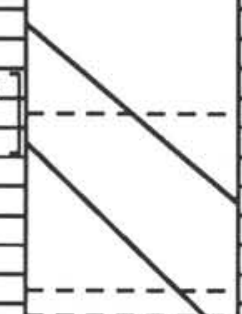

I $D$ ontengensis

B A tritubus

I B miralestensis

T 0 . petterssoni

$T$ D. laticonus

T S. wolffii

B. S. berminahami

B B. bramlettei

B D. nuahesi

B 0 entongensis

Th oncononsis -

I L thornbural

I C. cernuta
Site 728

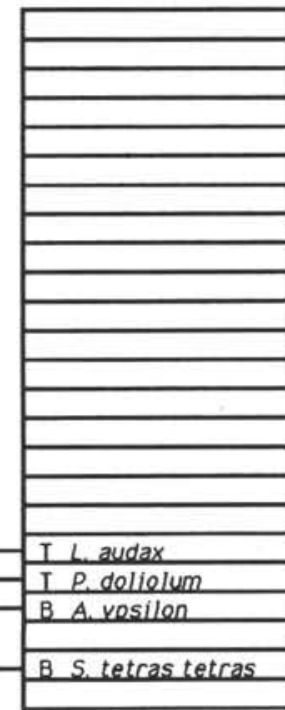

I S ambus

I D. oenultima

I s. omnitubus

I S. delmentensis

I S. cerona

I S. iehnsoni

B S. ambus

I C. caepa

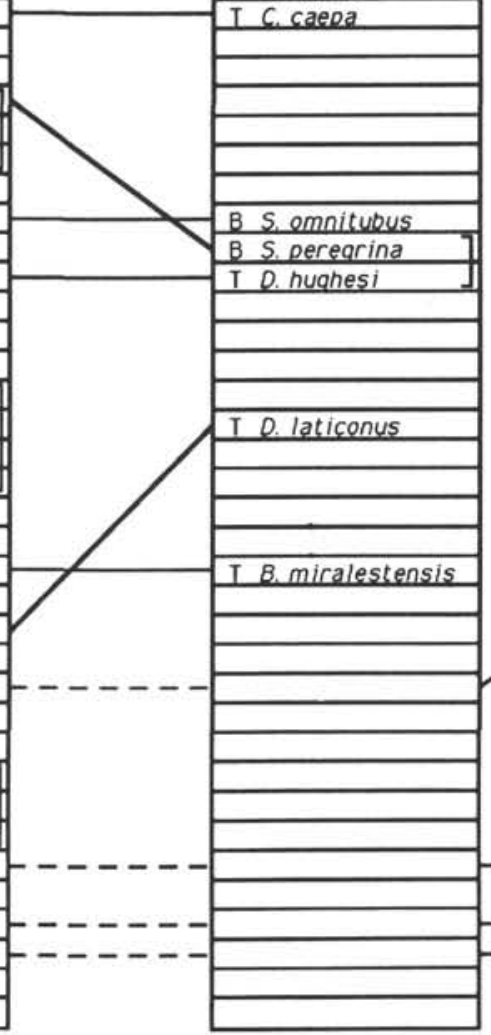

Site 730

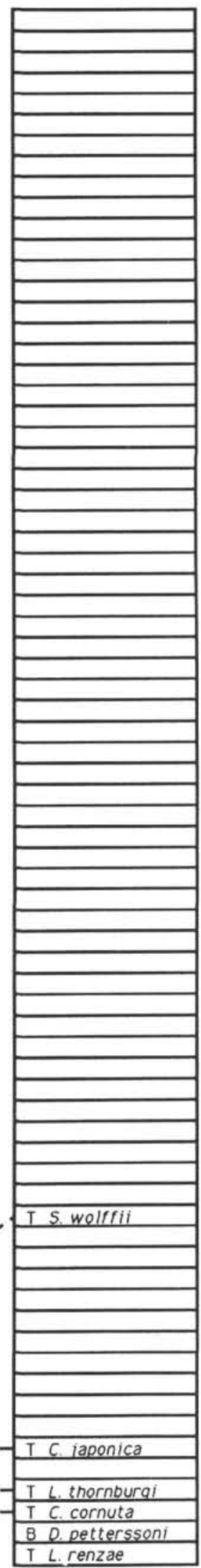


Table 2. Summary of radiolarian species which constitute, in part, the upwelling assemblages from the Oman margin and the Peru margin.

\begin{tabular}{|c|c|c|}
\hline & Oman margin & Peru margin \\
\hline $\begin{array}{l}\frac{U}{E} \\
\frac{\Delta}{D} \\
\text { ড. }\end{array}$ & $\begin{array}{l}\text { Cypassis irregularis (rare) } \\
\text { Dictyophimus infabricatus (rare) } \\
\text { Lamprocyrtis maritalis ventricosa (rare) } \\
\text { Collosphaera sp. aff. C. huxleyi } \\
\text { Eucyrtidium sp. } \\
\text { Anthocyrtidium sp. } \\
\text { Actinomma spp. group } \\
- \\
- \\
-\end{array}$ & $\begin{array}{l}\text { Cypassis irregularis (common) } \\
\text { Dictyophimus infabricatus (common) } \\
\text { Lamprocyrtis maritalis ventricosa (common) } \\
\text { Collosphaera sp. aff. C. huxleyi } \\
- \\
- \\
- \\
\text { Plectacantha cremastoplegma } \\
\text { Ptercanium grandiporus } \\
\text { Pseudocubus warreni }\end{array}$ \\
\hline 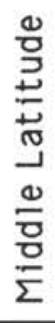 & $\begin{array}{l}\text { Acrosphaera murrayana group } \\
\text { Eucyrtidium calvertense } \\
\text { Eucyrtidium teuscheri group } \\
\text { Botryostrobus bramlettei pretumidulus } \\
\text { Botryostrobus bramlettei tumidulus } \\
\text { Lamprocyrtis daniellae } \\
\text { Streblacantha circumtexta }\end{array}$ & $\begin{array}{l}\text { Acrosphaera murrayana group } \\
\text { Eucyrtidium calvertense } \\
\text { Eucyrtidium teuscheri group } \\
\text { Botryostrobus bramlettei pretumidulus } \\
\text { Botryostrobus bramlettei tumidulus } \\
\text { Lamprocyrtis daniellae } \\
\text { Streblacantha circumtexta }\end{array}$ \\
\hline $\begin{array}{l}\bar{J} \\
\frac{0}{\circ} \\
\text { 은 } \\
\text { - }\end{array}$ & $\begin{array}{l}\text { Cycladophora davisiana } \\
\text { Lamprocyrtis neoheteroporos } \\
\text { Lamprocyrtis nigriniae (rare) } \\
\text { Lithostrobus sp. cf. L. hexagonalis (few) } \\
\text { Phormostichoartus crustula (rare) } \\
\text { Eucyrtidium infundibulum }\end{array}$ & $\begin{array}{l}\text { Cycladophora davisiana } \\
\text { Lamprocyrtis neoheteroporos } \\
\text { Lamprocyrtis nigriniae (common) } \\
\text { Lithostrobus sp. cf. L. hexagonalis (common) } \\
\text { Phormostichoartus crustula (abundant) } \\
\text { Eucyrtidium infundibulum }\end{array}$ \\
\hline
\end{tabular}

it is accompanied by $B$. b. tumidulus. Working upcore, $B . b$. tumidulus is present over the length of one or two cores and then is absent until the base of the $P$. prismatium Zone (about $2.5 \mathrm{Ma}$ ). Its reappearance coincides with the LAD of $B$. $b$. pretumidulus. $B$. b. tumidulus continues to the top of the recovered sequences. Both morphotypes are abundant in sediments from the Peru margin, but data there also suggest that the lineage proposed by Caulet (1979) needs to be re-examined. In Hole $683 \mathrm{~A}$ of Leg $112, B$. b. tumidulus is shown to extend down to the $D$. antepenultima Zone and in Site $685 \mathrm{~A} B$. b. pretumidulus extends well into the Pleistocene. Precise definition and the determination of lineages of the various multisegmented Artostrobiids will probably require detailed morphometrics (see, for example, Boltovskoy and Vrba, 1989).

Lamprocyrtis daniellae was first described by Caulet (1986) from the southwest Pacific (DSDP Leg 90) and may have an important link to the $L$. heteroporos $\rightarrow L$. nigriniae lineage. It is rare, but consistently present, in the early $S$. pentas Zone of DSDP Site 586B and ODP Sites 721, 722, and 731. L. daniellae is reported herein for the first time from Indian Ocean sediments. In the Leg 112 material off Peru it was found to have a narrow range in the early Pliocene and is more abundant than in the Leg 90 material.

Streblacantha circumtexta was first described by Jörgensen (1900) and subsequently by Bjørklund (1976), from the Norwegian Sea. It is also commonly found in Mediterranean sediments (J. P. Caulet, pers. comm., 1988). The species is consistently present in small numbers from the $D$. antepenultima
Zone to the Recent in Site 722. It is present in Pleistocene sediments (Site 685A) recovered during Leg 112

\section{ENHANCED TROPICAL SPECIES WHICH ARE UNUSUALLY ABUNDANT AND/OR ROBUST IN SOME AREAS OF UPWELLING}

This category is something of a mixed bag. It contains forms such as $C$. davisiana and $L$. neoheteroporos which are found universally, but which are generally more abundant in middle and/or high latitudes than in tropical areas.

C. davisiana is not only a characteristic element of upwelling assemblages, but is also a reliable stratigraphic marker with a generally synchronous FAD of 2.42-2.44 m.y., although Hays et al. (1989) found this datum to be diachronous between the eastern (2.4 Ma) and central (2.7 Ma) Pacific. The species is more abundant in the Oman margin/Owen Ridge material than in the open tropical ocean.

Lamprocyrtis neoheteroporos was found to be particularly robust in the Oman margin sediments and, to a lesser degree, in the Peru margin material. Its apparent descendant, L. nigriniae, is also generally more abundant in middle latitudes, but was found to be extraordinarily well developed and variable in the Peru margin material (Granlund and Caulet, in prep.). It is present in low numbers in the Oman margin material, but is more robust and more abundant in material recovered from beneath the Somali Current (Caulet and Nigrini, in prep.).

Pterocorys minythorax is particularly abundant and well developed in its type locality off Peru, but is rare in most tropical 
areas (Caulet and Nigrini, 1988). It is absent from the Oman material.

Lithostrobus sp. cf. L. hexagonalis was described by Nigrini (1968) as an element of the upwelling Peru margin assemblage. In fact, it now seems that this species is present in most tropical sediments, but it is more abundant and more robust in Peru margin sediments. It is consistently present, but neither abundant nor particularly robust in sediments from the Oman margin. The species does not seem to be stratigraphically interesting.

The following species are included as potentially interesting elements of the upwelling assemblage, but more needs to be known about their geographic and stratigraphic distribution.

Phormostichoartus crustula is abundant in the Peru margin material, but has a sporadic distribution in the Oman material. In the Peru sediments its last common occurrence is in sediments at least as young as $0.4 \mathrm{~m}$.y., whereas in the Oman material its LAD seems to be much lower, about 3.5 m.y.

Eucyrtidium infundibulum is found in both the Peru and Oman material. However, the morphotypic limits of the species are not presently well enough defined, nor is its general geographic distribution sufficiently well understood, for it to be considered, with certainty, as a characteristic member of the upwelling assemblage.

\section{STRATIGRAPHY OF UPWELLING SPECIES}

The ranges of several species thought to be characteristic of an upwelling assemblage are shown in Figure 3. Some of these are of interest in further defining the strength of, or pulses in, the upwelling mechanism. There is an obvious change in the fauna at the base of the $S$. pentas Zone $(\sim 4.7 \mathrm{Ma})$. At this level there is an interim last appearance datum of $C$. sp. aff. C. huxleyi, the first appearance datum of Eucyrtidium sp. and the first common occurrence of Actinomma spp. A. murrayana group is common between about $9.6 \mathrm{Ma}$ and at least $11.0 \mathrm{Ma}$ below which recovered material is too poor for meaningful analysis. It is rare between 9.6 and $4.7 \mathrm{~m}$.y. above which point it is again common. Anthocyrtidium sp. also first appears near the base of the $S$. pentas zone, but is too rare to be considered as a reliable indicator of faunal change. Additional first appearances at this level for $B$. bramlettei pretumidulus, B. bramlettei tumidulus, and Lamprocyrtis daniellae probably have more to do with as-yet-undocumented evolutionary changes than with a response to upwelling. Similarly, the FAD of $C$. davisiana at $2.4 \mathrm{Ma}$ is an evolutionary event independent of any upwelling mechanism.

A second, less convincing, change in the fauna occurs at the top of the $P$. prismatium Zone $(\sim 1.5 \mathrm{Ma})$ with the reappearance of $C$. sp. aff. $C$. huxleyi, the first rare occurrences of $D$. infabricatus and $L$. maritalis ventricosa and the last appearance of Eucyrtidium sp.

Except for $A$. murrayana the most convincing signals come from those species which are considered herein to be endemic to upwelling, although the presence of both the displaced temperate and enhanced tropical species contribute to the overall character of the assemblage along with the absence of several common tropical biomarkers. It would be useful to further pursue both the taxonomy and distribution of the $A$. murrayana group to determine the exact geographic and stratigraphic distribution of members of this group, and particularly, to determine whether the forms observed in the Crozet Basin are identical to those observed in the Oman margin material. In addition, it should be noted that $A$. murrayana group and $C$. sp. aff. $C$. huxleyi display opposite responses to the upwelling signal. Further taxonomic work is required to understand the relationship between these forms.

The displaced temperate members of the assemblage indicate cooler water conditions than are normally found in tropical wa- ters. It is possible that these forms have been carried northward by surface currents. The enhanced tropical species also suggest cooler water in that they display enlargement or thickening of the shell which is a characteristic response to cooler waters.

\section{SUMMARY}

This study represents the first detailed analysis of the radiolarian fauna from the Oman margin upwelling area. The assemblage is unique in two ways: (1) many common tropical species, some of which are biomarkers, are missing; and (2) some forms not commonly found in tropical sediments are present in the material.

Previous radiolarian studies (Nigrini, 1968; Molina-Cruz, $1977,1984)$ of upwelling assemblages have concentrated on the Peru margin. Comparison, herein, of the assemblage found there (ODP Leg 112) with the Oman margin material indicates that there is a radiolarian assemblage unique to areas of upwelling (or, at least, indicative of cool deep waters). The fact that these comparable faunas have been identified in two such geographically widely separated areas suggests that a radiolarian upwelling assemblage may be globally recognizable. It is necessary now to test this theory in other upwelling areas.

It was further determined that the elements of this upwelling fauna may be divided into three categories: (1) endemic upwelling: species which are endemic to upwelling; (2) displaced temperate: forms which are abundant in middle latitudes, but which can be found in tropical areas influenced by upwelling; and (3) enhanced tropical: forms found in tropical sediments, but which are more abundant and/or more robust in areas of upwelling. A pulse or strengthening of the upwelling mechanism is indicated by a marked faunal change at about $4.7 \mathrm{Ma}$ and another, less obvious, change occurs near the Pliocene-Pleistocene boundary. In addition, there is an indication of the termination of another upwelling pulse at about $9.6 \mathrm{Ma}$. The beginning of this earliest event probably coincides with the first appearance of siliceous fauna in the ODP Leg 117 material at about $11.9 \mathrm{Ma}$.

\section{ACKNOWLEDGMENTS}

My thanks go first to the drilling, marine, and technical crews of the JOIDES Resolution for the fine job they performed during the recovery, often at a hectic pace, of a record amount of core. I am grateful also to Chevron Oil Field Research Company (La Habra, CA) for the use of their laboratory facilities for sample preparation and to Michelle Destarac (Paris) for assistance with the photographs. Partial funding for post-cruise studies was provided by the U.S. Science Advisory Committee.

I wish to thank my colleague, Jean Pierre Caulet, for numerous discussions concerning the nature and composition of faunas associated with upwelling. And finally, my thanks go to my family for tolerating a seagoing mother and to my children for packing themselves off to college.

\section{REFERENCES}

Bailey, J. W., 1856. Notice of microscopic forms found in the soundings of the Sea of Kamtschatka-with a plate. Am. J. Sci., 22:64:1-6.

Baker, C., 1983. Evolution and hybridization in the radiolarian genera Theocorythium and Lamprocyclas. Paleobiology, 9:341-354.

Benson, R. N., 1966. Recent Radiolaria from the Gulf of California [Ph.D. dissert.]. Minnesota Univ.

Bjørklund, K. R., 1976. Radiolaria from the Norwegian Sea, Leg 38 of the Deep Sea Drilling Project. In Talwani, M., Udintsev, G., et al., Init. Repts. DSDP, 38: Washington (U.S. Govt. Printing Office), 1101-1168.

1977. Actinomma haysi, n.sp., its Holocene distribution and size variation in Atlantic Ocean sediments. Micropaleontology, 23: 114-126. 
Boltovskoy, D., and Vrba, A., 1989. Latitude-related shell patterns in Radiolaria: Botryostrobus auritus/australis morphotypes in the Equatorial to Antarctic Pacific. Mar. Micropaleontol., 13:309-323.

Campbell, A. S., and Clark, B. L., 1944. Miocene radiolarian faunas from southern California. Spec. Pap.-Geol. Soc. Am., 51:1-76.

Caulet, J., 1971. Contribution à l'étude de quelques Radiolaires Nassellaires des boues de la Méditerranée et du Pacifique. Cahiers de micropaléontologie Série 2, No. 10. Arch. Originale Cent. Doc. C.N.R.S., 498:1-10.

1979. Les dépots à radiolaires d’âge Pliocène superieur a Pleistocène dans l'océan Indien central: nouvelle zonation biostratigraphique (Radiolarian upper Pliocene-Pleistocene deposits in the central Indian Ocean; new biostratigraphic zonation). Mem. Mus. Nat. Hist. Nat., Ser. C, 43:119-141.

Caulet, J. P., 1986. Radiolarians from the southwest Pacific. In Kennett, J. P., von der Borch, C. C., et al., Init. Repts. DSDP, 90: Washington (U.S. Govt. Printing Office), 835-861.

Caulet, J. P., and Nigrini, C., 1988. The genus Pterocorys (Radiolaria) from the tropical late Neogene of the Indian and Pacific Oceans. Micropaleontology, 34:217-235.

in prep. Upwelling radiolarian fauna from the area of the Somali Current.

De Wever, P., Caulet, J. P., and Bourgois, J., in press. Radiolarian biostratigraphy from ODP Leg 112 on the Peru margin. In Suess, E., von Huene, R., et al., Proc. ODP, Sci. Results, 112: College Station, TX (Ocean Drilling Program).

Ehrenberg, C. G., 1844a. Uber 2 neue Lager von Gebirgsmassen aus Infusorien als Meeres-Absatz in Nord-Amerika und eine Vergleichung derselben mit den organischen Kreide-Gebilden in Europa und Afrika. Königl. Preuss. Akad. Wiss. Berlin, Bericht, Jahre 1844:57-97.

$1844 \mathrm{~b}$. Einige vorlaufige Resultate seiner Untersuchungen der ihm von der Sudpolreise des Captain Ross, so wie von den Herren Schayer und Darwin zugekommenen Materialien über das Verhalten des kleinsten Lebens in den Oceanen und den grossten bisher zuganglichen Tiefen des Weltmeeres. Königl. Preuss. Akad. Wiss. Berlin, Bericht, Jahre 1844:182-207.

1854. Mikrogeologie, das Erden und Felsen schaffende Wirken des unsichtbar kleinen selbständigen Lebens auf der Erde: Leipzig (Leopold Voss), 1-88.

1860. Uber den Tiefgrund des stillen Oceans zwischen Californien und den Sandwich-Inseln aus bis 15600 Tiefe nach Lieutenant Brooke. Königl. Preuss. Akad. Wiss. Berlin, Monatsberichte, 819-833.

1861. Uber die Tiefgrund-Verhaltnisse des Oceans am Einegange der Davisstrasse und bei Island. Königl. Preuss. Akad. Wiss. Berlin, Monatsberichte, 275-315.

1872a. Mikrogeologische Studien als Zusammenfassung der Beobachtungen des kleinsten Lebens der Meeres-Tiefgrunde aller Zonen und dessen geologischen Einfluss. Königl. Preuss. Akad. Wiss. Berlin, Monatsberichte, 265-322.

1872b. Mikrogeologische Studien über das kleinste Leben der Meeres-Tiefgrunde aller Zonen und dessen geologischen Einfluss. Königl. Akad. Wiss. Berlin, Abh., 131-39.

Goll, R. M., 1980. Pliocene-Pleistocene Radiolaria from the East Pacific Rise and the Galapagos spreading center, Deep Sea Drilling Project Leg 54. In Rosendahl, B. R., Hekinian, R., et al., Init. Repts. DSDP, 5: Washington (U. S. Govt. Printing Office), 425454.

Granlund, A., and Caulet, J. P., in prep. Morphometric study of Lamprocyrtis nigriniae from ODP Leg 112 (Pacific Ocean)-paleoenvironmental and evolutionary interpretations.

Haeckel, E., 1887. Report on the radiolaria collected by H.M.S. Challenger during the years 1873-1876. Rep. Sci. Results of H.M.S. Challenger 1873-6, 18.

Hays, J. D., 1965. Radiolaria and late Tertiary and Quaternary history of Antarctic seas. In Llano, G. A. (Ed.), Biology of the Antarctic Seas II: Am. Geophys. Union Antarct. Res. Ser., 5:125-184.

1970. Stratigraphy and evolutionary trends of Radiolaria in North Pacific deep sea sediments. In Hays, J. D. (Ed.), Geological Investigations of the North Pacific. Mem. Geol. Soc. Am., 126:185218.

Hays, P. E., Pisias, N. G., and Roelofs, A. K., 1989. Paleoceanography of the eastern equatorial Pacific during the Pliocene: a high-resolution radiolarian study. Paleoceanography, 4:57-73.
Hilmers, C., 1906. Zur Kenntnis der Collosphaeriden. Kiel (Druck von C. Schaidt).

Johnson, D. A., and Nigrini, C., 1980. Radiolarian biogeography in surface sediments of the western Indian Ocean. Mar. Micropaleontol., 5:111-152.

1985. Synchronous and time-transgressive Neogene radiolarian datum levels in the equatorial Indian and Pacific Oceans. Mar. Micropaleontol., 9:489-523.

Johnson, D. A, Schneider, D. A., Nigrini, C. A., Caulet, J. P., and Kent, D. V., 1989. Pliocene-Pleistocene radiolarian events and magnetostratigraphic correlations for the tropical Indian Ocean. Mar. Micropaleontol., 14:33-66.

Jörgensen, E., 1900. Protophyten und Protozoen im Plankton aus der norwegischen Westkuste. Bergens Mus. Aarbog, 1899, 2.

1905. The protist plankton and the diatoms in bottom samples. Univ. Bergens Skr., 49-151.

Kellogg, D. E., 1976. Character displacement in the radiolarian genus Eucyrtidium. Evolution Lawrence Kans., 29:736-749.

Kling, S. A., 1973. Radiolaria from the eastern North Pacific, Deep Sea Drilling Project Leg 18. In Kulm, L. D., von Huene, R., et al., Init. Repts. DSDP, 18: Washington (U. S. Govt. Printing Office), $617-$ 671.

1977. Local and regional imprints on radiolarian assemblages from California coastal basin sediments. Mar. Micropaleontol., 2 : 207-221.

Lombari, G., and Boden, G., 1985. Modern radiolarian global distributions. Spec. Publ. Cushman Found. Foraminiferal. Res., 16A.

Martin, G. C., 1904. Radiolaria, Miocene: Baltimore (Maryland Geol. Surv., Johns Hopkins Press).

Molina-Cruz, A., 1977. Radiolarian assemblages and their relationship to the oceanography of the subtropical southeastern Pacific. Mar. Micropaleontol., 2:315-352.

1984. Radiolaria as indicators of upwelling processes: the $\mathrm{Pe}-$ ruvian connection. Mar. Micropaleontol., 9:53-75.

Moore, T. C., 1972. Mid-Tertiary evolution of the radiolarian genus $\mathrm{Ca}$ locycletta. Micropaleontology, 18:144-152.

Müller, J., 1855. Uber Sphaerozoum und Thalassicolla. Königl. Preuss. Akad. Wiss. Berlin, Bericht, 229-253.

1858. Uber die Thalassicollen, Polycystinen und Acanthometren des Mittelmeeres. Königl. Preuss. Akad. Wiss. Berlin, Abh., 162.

Nakaseko, K., 1963. Neogene Cyrtoidea (Radiolaria) from the Isozaki Formation in Ibaraki Prefecture, Sci. Rep., Coll. Gen. Educ. Osaka Univ., 12:165-198.

Nigrini, C., 1967. Radiolaria in pelagic sediments from the Indian and Atlantic Oceans. Bull. Scripps Inst. Oceanogr., 11:1-125.

1968. Radiolaria from eastern tropical Pacific sediments. Micropaleontology, 14:51-63.

1971. Radiolarian zones in the Quaternary of the equatorial Pacific Ocean. In Funnell, B. M., and Riedel, W. R. (Eds.), The Micropaleontology of Oceans: Cambridge (Cambridge Univ. Press), 443-461.

1974. Cenozoic Radiolaria from the Arabian Sea, DSDP Leg 23. In Davies, T. A., Luyendyk, B. P., et al., Init. Repts. DSDP, 26: Washington (U. S. Govt. Printing Office), 1051-1121.

1977. Tropical Cenozoic Artostrobiidae (Radiolaria). Micropaleontology, 23:241-269.

1985. Radiolarian biostratigraphy in the central equatorial Pacific. In Mayer, L., Theyer, F., Thomas, E., et al. Init. Repts. DSDP, 85: Washington (U.S. Govt. Printing Office), 511-551.

Nigrini, C., and Caulet, J.-P., 1988. The genus Anthocyrtidium (Radiolaria) from the tropical late Neogene of the Indian and Pacific Oceans. Micropaleontology, 34:341-360.

Nigrini, C., and Moore, T. C., 1979. A guide to modern radiolaria. Spec. Publ. Cushman Found. Foraminiferal Res., 16.

Petrushevskaya, M. G., 1967. Radiolyarii otryadov Spumellaria i Nassellaria antarkticheskoi oblasti (Antarctic Spumelline and Nasselline radiolarians). Issled. Fauny Morei, 4:1-186.

Petrushevskaya, M. G., and Kozlova, G. E., 1972. Radiolaria: Leg 14, Deep Sea Drilling Project. In Hayes, D. E., Pimm, A. C., et al., Init. Repts. DSDP, 14: Washington (U.S. Govt. Printing Office), 495-648.

Prell, W. L., Niitsuma, N., et al., 1989. Proc. ODP, Init. Repts., 117: College Station, TX (Ocean Drilling Program). 
Riedel, W. R., 1953. Mesozoic and late Tertiary Radiolaria of Rotti. J. Paleontol., 27:805-813.

1957. Radiolaria: a preliminary stratigraphy. In Pettersson, H. (Ed.), Rep. Swedish Deep-Sea Exped., 1947-1948, (Vol. 6): Goteborg (Elanders Boktryckeri Aktiebolag), 59-96.

1958. Radiolaria in Antarctic sediments. Rep. B.A.N.Z. Antarct. Res. Exped., Ser. B, 6:217-255.

, 1959. Oligocene and Lower Miocene Radiolaria in tropical Pacific sediments. Micropaleontology, 5:285-302.

Riedel, W. R., and Sanfilippo, A., 1970. Radiolaria, Leg 4, Deep Sea Drilling Project. In Bader, R. G., Gerard, R. D., et al., Init. Repts. DSDP, 4: Washington (U.S. Govt. Printing Office), 503-575.

1971. Cenozoic Radiolaria from the western tropical Pacific,

Leg 7. In Winterer, E. L., Riedel, W. R., et al., Init. Repts. DSDP, 7 (Pt. 2): Washington (U.S. Govt. Printing Office), 1529-1672.

, 1978. Stratigraphy and evolution of tropical Cenozoic radiolarians. Micropaleontology, 24:61-96.

Romine, K., and Moore, T. C., Jr., 1981. Radiolarian assemblage distributions and paleoceanography of the Eastern Equatorial Pacific Ocean during the last 127,000 years. Palaeogeogr., Palaeoclimatol., Palaeoecol., 35:281-314.

Sanfilippo, A., Burckle, L. H., Martini, E., and Riedel, W. R., 1973. Radiolarians, diatoms, silicoflagellates and calcareous nannofossils in the Mediterranean Neogene. Micropaleontology, 19:209-234.
Sanfilippo, A., and Riedel, W. R., 1970. Post-Eocene "closed" theoperid radiolarians. Micropaleontology, 16:446-462.

1974. Radiolaria from the west-central Indian Ocean and Gulf of Aden, DSDP Leg 24. In Fisher, R. L., Bunce, E. T., et al., Init. Repts. DSDP, 24: Washington (U.S. Govt. Printing Office), 9971035.

1980. A revised generic and suprageneric classification of the Artiscins (Radiolaria). J. Paleontol., 54:1008-1011.

Sanfilippo, A., Westberg-Smith, M. J., and Riedel, W. R., 1985. Cenozoic radiolaria. In Bolli, H. M., Saunders, J. B., and Perch-Nielsen, K. (Eds.), Plankton Stratigraphy: Cambridge (Cambridge Univ. Press), 631-712.

Schramm, C., 1984. Implications of radiolarian assemblages for the Late Quaternary paleoceanography of the eastern equatorial Pacific. Quat. Res., 24:204-218.

Strelkov, A. A., and Reshetnyak, V. V., 1971. Kolonialnye radiolyarii Spumellaria Mirovogo okeana (Colonial Spumellarian radiolarians of the world ocean). Issled. Fauny Morei, 9:295-418.

Date of initial receipt: 4 August 1989

Date of acceptance: 29 January 1990

Ms 117B-132 
DISPLACED TEMPERATE SPECIES

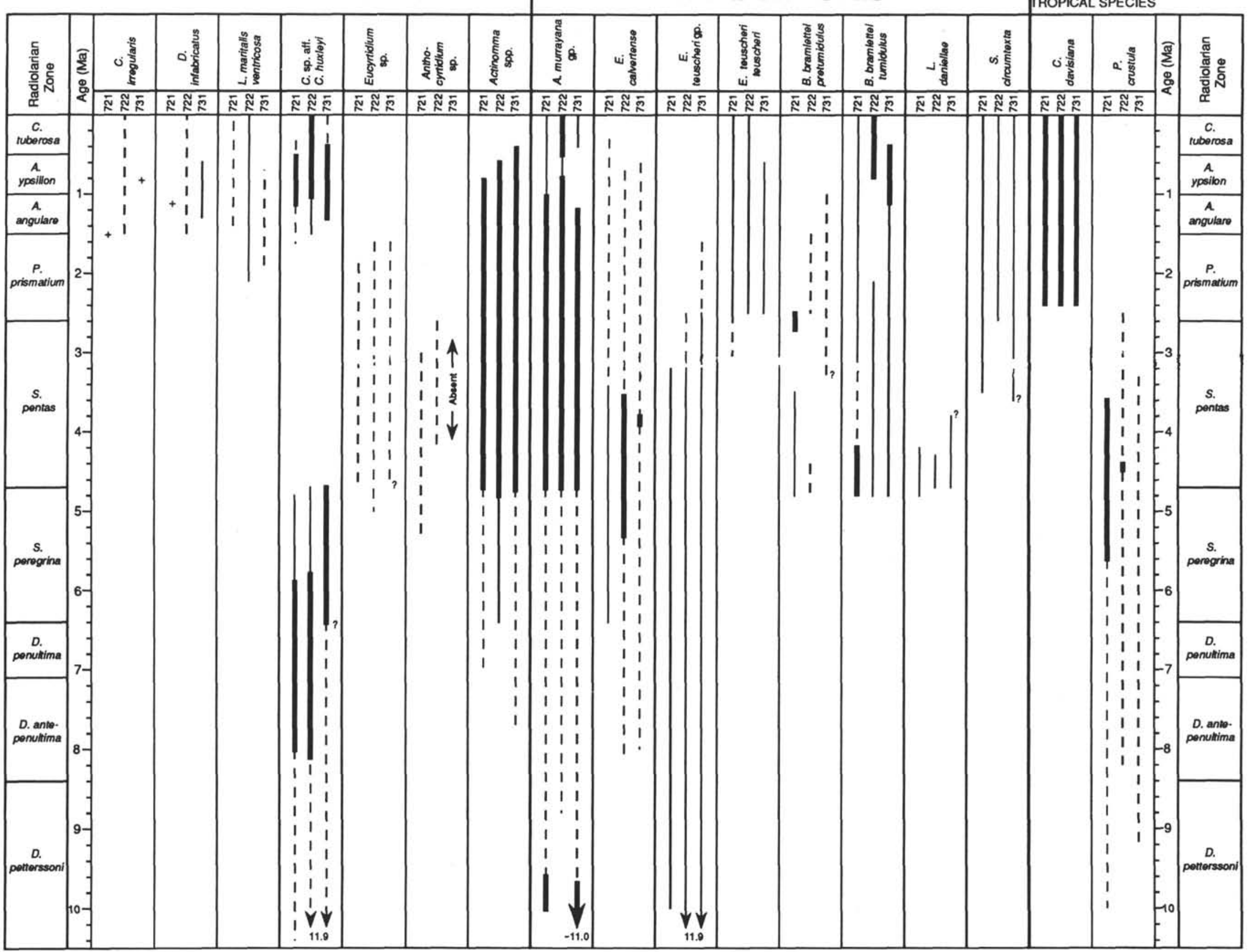




\section{APPENDIX A \\ Raw Data for Leg 117 Sites}

The following appendix comprises tables of raw data for each of the Leg 117 sites in which radiolarians were recovered. $\mathbf{P}=$ present; $+=$ rare (one or two specimens); - = searched for and found to be absent; $?=$ dubious identification. Overall radiolarian abundance is given as $\mathrm{C}=$ common; $\mathbf{F}=$ few $\mathbf{R}=$ rare; $-=$ absent. Preservation is given as $\mathbf{G}=$ good; $\mathrm{M}=$ moderate; $\mathrm{P}=$ poor.

\section{APPENDIX B \\ Species List}

Acrobotrys tritubus Riedel. Riedel, 1957, p. 80, pl. 1, fig. 5.

Acrosphaera cyrtodon (Haeckel). Odontosphaera cyrtodon in Haeckel, 1887 , p. 102, pl. 5, fig. 6; Acrosphaera cyrtodon (Haeckel) in Strelkov and Reshetnyak, 1971, p. 344, pl. 7, fig. 51, pl. 8, fig. 54; text-fig. 24.

Acrosphaera murrayana (Haeckel). Choenicosphaera murrayana in Haeckel, 1887, p. 102, pl. 8, fig. 4. Acrosphaera murrayana (Haeckel) in Hilmers, 1906, p. 63.

Acrosphaera trepanata (Haeckel). Trypanosphaera trepanata in Haeckel, 1887 , p. 110, pl. 5 fig. 4; Acrosphaera trepanata (Haeckel) in Goll, 1980 , p. 436 , pl. 2 , figs. $6-9$.

Actinomma haysi Bjørklund. Bjørklund, 1977, p. 117, pl. 1, figs. A-L.

Amphirhopalum ypsilon Haeckel. Haeckel, 1887, p. 552; Nigrini, 1971, p. 447 , pl. 34.1 , figs. $7 \mathrm{a}-\mathrm{c}$.

Anthocyrtidium angulare Nigrini. Nigrini, 1971, p. 445, pl. 34.1, figs. 3a-b; Nigrini and Caulet, 1988, p. 343, pl. 1, figs. 1-2.

Anthocyrtidium nosicaae Caulet. Caulet, 1979, p. 132, pl. 2, fig. 6; Nigrini and Caulet, 1988, p. 351, pl. 1, figs. 15-17.

Botryostrobus auritus/australis (Ehrenberg) group. Lithocampe australe Ehrenberg, 1844b, p. 187; 1854, pl. 35A, 21, fig. 18. Botryostrobus auritus/australis (Ehrenberg) group in Nigrini, 1977, p. 246, pl. 1, figs. 2-5.

Botryostrobus bramlettei bramlettei (Campbell and Clark). Lithomitra bramlettei in Campbell and Clark, 1944, p. 53, pl. 7, figs. 10-14. Botryostrobus bramlettei bramlettei (Campbell and Clark) in Caulet, 1979 , p. 129 , pl. 1 , fig. 8

Botryostrobus bramlettei pretumidulus Caulet. Caulet, 1979, p. 129, pl. 1 , fig. 5.

Botryostrobus bramlettei tumidulus (Bailey). Eucyrtidium tumidulus in Bailey, 1856, p. 5, pl. 1, fig. 11; Botryostrobus bramlettei tumidulus (Bailey) in Caulet, 1979, p. 131, pl. 1, fig. 9

Botryostrobus miralestensis (Campbell and Clark). Dictyocephalus miralestensis in Campbell and Clark, 1944, p. 45, pl. 6, figs. 12-14; Botryostrobus miralestensis (Campbell and Clark) in Petrushevskaya and Kozlova, 1972, p. 539, pl. 24, fig. 31.

Buccinosphaera invaginata Haeckel. Haeckel, 1887, p. 99, pl. 5, fig. 11; Nigrini, 1971, p. 445, pl. 34.1, fig. 2.

Calocycletta caepa Moore. Moore, 1972, p. 149, pl. 2, figs. 4-7.

Collosphaera sp. aff. C. huxleyi Müller. Müller, 1855, p. 238; 1858, p. 55, pl. 8, figs. 6-9; Johnson and Nigrini, 1980, p. 147, pl. 1, fig. 6, pl. 4 , fig. 14.

Collosphaera tuberosa Haeckel. Haeckel, 1887, p. 97; Nigrini, 1971, p. 445 , pl. 34.1, fig. 1 .

Cycladophora davisiana (Ehrenberg). Cycladophora (?) davisiana in Ehrenberg, 1861, p. 297; Theocalyptra davisiana (Ehrenberg) in Riedel, 1958 , p. 239 , pl. 4 , figs. $2-3$, text-fig. 10 .

Cypassis irregularis Nigrini. Nigrini, 1968, p. 53, pl. 1, figs. 2a-c.

Cyrtocapsella cornuta (Haeckel). Cyrtocapsa (Cyrtocapsella) cornuta in Haeckel, 1887, p. 1513, pl. 78, fig. 9; Cyrtocapsella cornuta (Haeckel) in Sanfilippo and Riedel, 1970, p. 453, pl. 1, figs. 19, 20.

Cyrtocapsella japonica (Nakaseko). Eusyringium japonicum in Nakaseko, 1963, p. 193, pl. 4, figs. 1-3; Cyrtocapsella japonica (Nakaseko) in Sanfilippo and Riedel, 1970, p. 452, pl. 1, figs. 13-15.

Cyrtocapsella tetrapera (Haeckel). Cyrtocapsa (Cyrtocapsella) tetrapera in Haeckel, 1887, p. 1512, pl. 75, fig. 12; Cyrtocapsella tetrapera (Haeckel) in Sanfilippo and Riedel, 1970, p. 453, pl. 1, figs. 16-18.

Dendrospyris bursa Sanfilippo and Riedel. Sanfilippo et al., 1973, p. 217, pl. 2, figs. 9-13.

Diartus hughesi (Campbell and Clark). Ommatocampe hughesi in Campbell and Clark, 1944, p. 23, pl. 3, fig. 12; Diartus hughesi (Campbell and Clark) in Sanfilippo and Riedel, 1980, p. 1010.
Diartus petterssoni (Riedel and Sanfilippo). Cannartus (?) petterssoni in Riedel and Sanfilippo, 1970, p. 520, pl. 14, fig. 3; Diartus petterssoni (Riedel and Sanfilippo), in Sanfilippo and Riedel, 1980, p. 1010.

Dictyocoryne ontongensis Riedel and Sanfilippo. Riedel and Sanfilippo, 1971 , p. 1588 , pl. 1E, figs. 1,2, pl. 4, figs. 9-11.

Dictyophimus infabricatus Nigrini. Nigrini, 1968, p. 56, pl. 1, fig. 6 .

Dictyophimus splendens (Campbell and Clark). Pterocorys (Pterocyrtidium) splendens in Campbell and Clark, 1944, p. 46, pl. 6, figs. 1920.

Didymocyrtis antepenultima (Riedel and Sanfilippo). Ommatartus antepenultima in Riedel and Sanfilippo, 1970, p. 521, pl. 14, fig. 4. Didymocyrtis antepenultima (Riedel and Sanfilippo) in Sanfilippo and Riedel, 1980, p. 1010.

Didymocyrtis laticonus (Riedel). Cannartus laticonus in Riedel, 1959, p. 291, pl. 1, fig. 5; Didymocyrtis laticonus (Riedel) in Sanfilippo and Riedel, 1980, p. 1010.

Didymocyrtis penultima (Riedel). Panarium penultimum in Riedel, 1957, p. 76, pl. 1, fig. 1; Didymocyrtis penultima (Riedel) in Sanfilippo and Riedel, 1980, p. 1010.

Dorcadospyris alata (Riedel). Brachiospyris alata in Riedel, 1959, p. 293, pl. 1, figs. 11, 12; Riedel and Sanfilippo, 1970, p. 523, pl. 15, fig. 5 .

Eucyrtidium acuminatum (Ehrenberg). Lithocampe acuminatum in Ehrenberg, 1844 a, p. 84 ; Nigrini, 1967 , p. 81 , pl. 8, figs. 3a, b.

Eucyrtidium calvertense Martin. Martin, 1904, p. 450, pl. 130, fig. 5.

Eucyrtidium infundibulum (Haeckel). Lithomitra infundibulum in Haeckel, 1887 , p. 1487 , pl. 79 , fig. 5 .

Eucyrtidium teuscheri Haeckel orthoporus Caulet. Caulet, 1986, p. 851 , pl. 5 , fig. 4

Eucyrtidium teuscheri Haeckel group. Haeckel, 1887, p. 1491, pl. 77, fig. 5; emend. Caulet, 1986, p. 850, pl. 5, figs. 1-8.

Eucyrtidium teuscheri Haeckel teuscheri Caulet. Caulet, 1986, p. 851, pl. 5, figs. 5-8.

Lamprocyclas maritalis Haeckel ventricosa Nigrini. Nigrini, 1968, p. 57, pl. 1 , fig. 9.

Lamprocyrtis daniellae Caulet. Caulet, 1986, p. 850, pl. 3, figs. 13-16.

Lamprocyrtis heteroporos (Hays). Lamprocyclas heteroporos Hays, 1965, p. 179, pl. 3, fig. 1. Lamprocyrtis heteroporos (Hays) in Kling, 1973, p. 639 , pl. 5 , figs. $19-21$, pl. 15 , figs. $4-5$.

Lamprocyrtis neoheteroporos Kling. Kling, 1973, p. 639, pl. 5, figs. 1718, pl. 15, figs. 4-5.

Lamprocyrtis nigriniae (Caulet). Conarachnium nigriniae in Caulet, 1971, p. 3, pl. 3, figs. 1-4, pl. 4, figs, 1-4; Lamprocyrtis nigriniae (Caulet) in Kling, 1977, p. 217, pl. 1, fig. 17.

Liriospyris parkerae Riedel and Sanfilippo, Riedel and Sanfilippo, 1971, p. 1590 , pl. 2 C, fig. 15 , pl. 5 , fig. 4 .

Lithelius minor Jörgensen. Jörgensen, 1900, p. 65, pl. 5, fig. 24; Benson, 1966 , p. 262 , pl. 17, figs. $9,10$.

Lithoperta renzae Sanfilippo and Riedel. Sanfilippo and Riedel, 1970, p. 454 , pl. 1 , figs. $21-23,27$.

Lithoperta thornburgi Sanfilippo and Riedel. Sanfilippo and Riedel, 1970 , p. 455 , pl. 2, figs. 4-6.

Lithostrobus sp. cf. L. hexagonalis Haeckel. Haeckel, 1887, p. 1475, pl. 79 , fig. 20. Nigrini, 1968, p. 58, pl. 1, fig. 10.

Lychnodictyum audax Riedel. Riedel, 1953, p. 810, pl. 85, fig. 9.

Octopyle stenozona Haeckel. Haeckel, 1887, p. 652, pl. 9, fig. 11.

Phormostichoartus(?) crustula (Caulet). Lithamphora crustula in Caulet, 1979 , p. 131, pl. 2, fig. 1.

Phormostichoartus doliolum (Riedel and Sanfilippo). Artostrobium doliolum in Riedel and Sanfilippo, 1971, p. 1599, pl. 1H, figs. 1-3, pl. 8 , figs. 14, 15; Nigrini, 1977 , p. 252 , pl. 1, fig. 14.

Phormostichoartus fistula Nigrini. Nigrini, 1977, p. 153, pl. 1, figs. 1113.

Phormostichoartus marylandicus (Martin). Lithocampe marylandicus in Martin, 1904, p. 450, pl. 130, fig. 4; Nigrini, 1977, p. 253, pl. 2, figs. 1-4.

Plectacantha cremastoplegma Nigrini. Nigrini, 1968, p. 55, pl. 1, fig. 3a-c, text-fig. 2.

Pseudocubus warreni Goll. Goll, 1980, p. 437, pl. 3, figs. 5-6.

Pterocanium grandiporus Nigrini. Nigrini, 1968, p. 57, pl. 1, fig. 7.

Pterocanium praetextum (Ehrenberg) eucolpum (Haeckel). Pterocanium eucolpum Haeckel, 1887, p. 1322, pl. 73, fig. 4. Pterocanium praetextum (Ehrenberg) eucolpum (Haeckel) in Nigrini, 1967, p. 70, pl. 7, fig. 2 . 


\section{NIGRINI}

Table 1. Raw data for stratigraphically important species in Holes 721A and 721B. For explanation of symbols see Appendix A introduction.

\begin{tabular}{|c|c|c|c|c|c|c|c|c|c|c|c|c|c|c|c|c|c|c|c|}
\hline Age & $\begin{array}{l}\text { Radiolarian } \\
\text { zone }\end{array}$ & Sample & $\begin{array}{l}\text { 巳 } \\
\text { 导 } \\
\text { 言 }\end{array}$ & 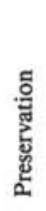 & 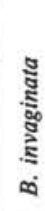 & 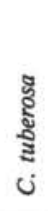 & 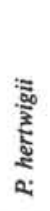 & 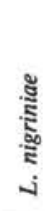 & 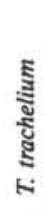 & 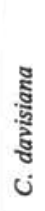 & 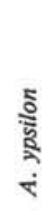 & 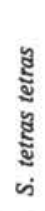 & 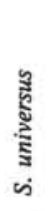 & 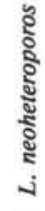 & 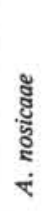 & 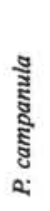 & 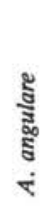 & 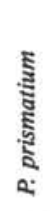 & 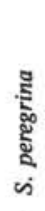 \\
\hline \multirow{9}{*}{ Quaternary } & C. tuberosa & A-1H-4, 85-87 & F & $\mathrm{M}$ & - & $\bar{D}$ & $\bar{n}$ & - & $\overline{0}$ & + & + & $\bar{D}$ & - & $\cdot$ & . & . & . & . & . \\
\hline & C. Tuberosa & A-1H-CC & C & G & - & $\mathbf{P}$ & $\mathbf{P}$ & $\mathrm{P}$ & $P$ & $\mathbf{P}$ & $\mathbf{P}$ & $\mathbf{P}$ & - & . & . & . & . & . & . \\
\hline & & A-2H-4, 85-87 & $\mathbf{F}$ & M & - & - & - & - & - & - & - & - & - & . & . & . & . & . & . \\
\hline & A. ypsilon? & A-2H-CC & F & $\mathbf{M}$ & - & - & - & - & - & - & - & - & - & . & . & . & . & . & . \\
\hline & A. Уponont & A-3H-CC & $\mathrm{F}$ & M & . & - & - & - & - & $\mathbf{P}$ & - & $\mathbf{P}$ & $\mathbf{P}$ & - & - & . & - & . & . \\
\hline & -- & A-4H-4, 85-87 & $\mathrm{F}$ & $\mathbf{M}$ & . & - & - & $\mathbf{P}$ & + & $\mathbf{P}$ & - & $\mathbf{P}$ & $\mathbf{P}$ & - & - & - & - & . & . \\
\hline & 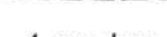 & A- $4 \mathrm{H}-\mathrm{CC}$ & C & G & . & - & 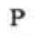 & - & $\mathbf{P}$ & $\mathrm{P}$ & $\mathbf{P}$ & $\mathrm{P}$ & $\mathbf{P}$ & $\mathbf{P}$ & $\mathbf{P}$ & $\mathbf{P}$ & $\mathbf{P}$ & . & . \\
\hline & A. angulare & A- $5 \mathrm{H}-4,85-87$ & C & G & . & . & - & - & $P$ & $P$ & $\mathbf{P}$ & $P$ & $\mathrm{P}$ & $\mathbf{P}$ & $P$ & $\mathbf{P}$ & $\mathbf{P}$ & - & . \\
\hline & & A-5H-CC & C & G & . & . & - & - & $P$ & $\mathbf{P}$ & $\mathbf{P}$ & $\mathbf{P}$ & $\mathbf{P}$ & $\mathbf{P}$ & $\mathbf{P}$ & $\mathbf{P}$ & $\mathbf{P}$ & - & . \\
\hline \multirow{21}{*}{ Pilocene } & & A-6H-4, 85-87 & C & G & . & . & . & . & - & $\mathbf{P}$ & $\mathbf{P}$ & $\mathbf{P}$ & $\mathbf{P}$ & $\mathrm{P}$ & $\mathbf{P}$ & $\mathbf{P}$ & - & $P$ & . \\
\hline & & A-6H-CC & $\mathrm{F}$ & M & . & . & . & . & - & $?$ & - & - & $\mathbf{P}$ & - & - & - & - & - & . \\
\hline & & A-7H-4, 85-87 & C & G & . & . & . & . & - & $\mathbf{P}$ & + & + & $\mathbf{P}$ & - & $\mathbf{P}$ & + & - & $P$ & . \\
\hline & P. prismatium & A-7H-CC & C & G & . & . & . & . & - & $\mathbf{P}$ & - & $\mathbf{P}$ & $\mathbf{P}$ & + & $\mathbf{P}$ & - & - & $\mathbf{P}$ & - \\
\hline & & A-8H-4, 85-87 & C & G & . & . & . & . & . & $\mathbf{P}$ & $\mathbf{P}$ & $\mathbf{P}$ & P & + & - & . & . & - & . \\
\hline & & A-8H-CC & C & G & . & . & . & . & . & $\mathbf{P}$ & $\mathbf{P}$ & $P$ & $\mathbf{P}$ & + & $\mathbf{P}$ & . & - & - & - \\
\hline & & A-9H-4, 85-87 & $\mathrm{F}$ & M & . & . & . & . & . & - & $\mathbf{P}$ & $\mathrm{P}$ & $\mathbf{P}$ & - & - & - & . & - & - \\
\hline & & A-9H-CC & C & G & . & . & . & . & . & - & $\mathbf{P}$ & $\mathbf{P}$ & $\mathbf{P}$ & . & - & $\mathbf{P}$ & . & - & $\mathbf{P}$ \\
\hline & & B-10X-4, 85-87 & F & $\mathbf{M}$ & . & . & . & . & . & + & + & - & $\mathbf{P}$ & . & - & . & . & . & $\mathrm{P}$ \\
\hline & & B-10X-CC & C & G & . & . & . & . & . & . & $\mathrm{P}$ & $\mathbf{P}$ & $\mathbf{P}$ & . & $\mathbf{P}$ & . & . & . & $\mathbf{P}$ \\
\hline & & B-11X-4, 85-87 & C & G & . & . & . & . & . & . & $\mathbf{P}$ & $\mathrm{P}$ & P & . & $?$ & . & . & . & $\mathrm{P}$ \\
\hline & & B-11X-CC & C & G & . & . & . & . & . & . & - & $\mathbf{P}$ & $\mathbf{P}$ & . & $\mathbf{P}$ & $\mathbf{P}$ & . & . & $P$ \\
\hline & & B-12X-CC & C & G & . & . & . & . & . & . & $\mathbf{P}$ & $\mathrm{P}$ & P & . & $\mathrm{P}$ & . & . & . & $\mathrm{P}$ \\
\hline & & B-13X-4, 85-87 & C & G & . & . & . & . & . & . & $\mathbf{P}$ & $\mathrm{P}$ & $\mathbf{P}$ & . & $\mathbf{P}$ & . & . & + & $\mathbf{P}$ \\
\hline & 3. pentas & B-13X-CC & C & G & . & . & . & . & . & . & - & $\mathbf{P}$ & $\mathbf{P}$ & . & + & . & . & + & $\mathbf{P}$ \\
\hline & & B-14X-4, 85-87 & C & M & . & . & . & . & . & . & - & - & $\mathbf{P}$ & . & $\mathbf{P}$ & . & . & . & $\mathbf{P}$ \\
\hline & & B-14X-CC & C & G & . & . & . & . & . & . & - & - & $\mathbf{P}$ & . & $\mathbf{P}$ & . & . & . & $\mathbf{P}$ \\
\hline & & B-15X-4, 85-87 & C & G & . & . & . & . & . & . & . & . & $\mathbf{P}$ & . & $P$ & . & . & . & $\mathbf{P}$ \\
\hline & & B-15X-CC & C & G & . & . & . & . & . & . & . & . & $\mathbf{P}$ & . & $P$ & . & . & + & $\mathbf{P}$ \\
\hline & & B-16X-4, 85-87 & C & G & . & . & . & . & . & . & . & . & $\mathbf{P}$ & . & $\mathrm{P}$ & . & . & . & $\mathbf{P}$ \\
\hline & & B-16X-CC & C & G & . & . & . & . & . & . & . & . & P & . & $\mathrm{P}$ & . & . & . & $\mathbf{P}$ \\
\hline \multirow{29}{*}{ Miocene } & & B-17X-4, 85-87 & C & G & . & . & . & . & . & . & . & . & $\mathbf{P}$ & . & . & . & . & . & $\mathbf{P}$ \\
\hline & & B-17X-CC & C & G & . & . & . & . & . & . & . & . & $\mathbf{P}$ & . & . & . & . & . & $\mathbf{P}$ \\
\hline & & B-18X-4, 85-87 & C & G & . & . & . & . & . & . & . & . & $\mathbf{P}$ & . & 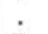 & . & . & . & $\mathbf{P}$ \\
\hline & & B-18X-CC & C & G & . & . & . & . & . & . & . & . & $\mathbf{P}$ & . & $P$ & . & . & . & $\mathrm{P}$ \\
\hline & & B-19X-4, 85-87 & C & G & . & . & . & . & . & . & . & . & $\mathbf{P}$ & , & . & . & . & . & $\mathbf{P}$ \\
\hline & & B-19X-CC & C & G & . & . & . & . & . & . & . & . & $\mathrm{P}$ & . & $P$ & . & . & & P \\
\hline & & B-20X-4, 85-87 & C & G & . & . & . & . & . & . & . & . & P & . & $\mathbf{P}$ & . & . & . & $\mathbf{P}$ \\
\hline & S. peregrina & B-20X-CC & F & G & . & . & . & . & . & . & . & . & $\mathbf{P}$ & . & . & . & . & . & $\mathbf{P}$ \\
\hline & & B-21X-CC & C & G & . & . & . & . & . & . & . & . & $\mathbf{P}$ & . & . & . & . & . & $\mathbf{P}$ \\
\hline & & B- $22 X-4,85-87$ & C & G & . & . & . & . & . & . & . & . & $\mathbf{P}$ & . & $\mathbf{P}$ & . & . & . & $\mathbf{P}$ \\
\hline & & B-22X-CC & C & G & , & . & . & . & . & . & . & . & $\mathbf{P}$ & . & . & . & . & . & $P$ \\
\hline & & B-23X-3, 85-87 & C & G & . & . & . & . & . & . & . & . & $\mathbf{P}$ & . & . & . & . & . & $\mathbf{P}$ \\
\hline & & B-23X-CC & C & G & . & . & . & . & . & . & . & . & $\mathbf{P}$ & . & . & . & . & . & $\mathbf{P}$ \\
\hline & & B- $24 X-3,85-87$ & C & G & . & . & . & . & . & . & . & . & $\mathbf{P}$ & . & . & . & . & . & $\mathbf{P}$ \\
\hline & & B-24X-CC & C & G & . & . & . & . & . & . & . & . & $\mathbf{P}$ & . & $\mathbf{P}$ & . & . & . & $\mathbf{P}$ \\
\hline & & B-25X-4, $85-87$ & C & G & . & . & . & . & . & . & . & . & $\mathbf{P}$ & . & . & . & . & . & $\mathbf{P}$ \\
\hline & & B-25X-CC & C & G & . & . & . & . & . & . & . & . & $\mathbf{P}$ & . & . & . & . & . & $\mathbf{P}$ \\
\hline & D. penultima & B- $26 X-4,85-87$ & C & G & . & . & . & . & . & . & . & . & $\mathbf{P}$ & . & . & . & . & . & $\mathbf{P}$ \\
\hline & & B-26X-CC & C & G & . & . & . & . & . & . & . & . & $\mathbf{P}$ & . & . & . & . & . & $\mathbf{P}$ \\
\hline & & B- $27 X-4,85-87$ & C & G & . & . & . & . & . & . & . & . & $\mathbf{P}$ & . & . & . & . & . & $\mathbf{P}$ \\
\hline & & B-27X-CC & C & G & . & . & . & . & . & . & . & . & $\mathbf{P}$ & . & . & . & . & . & $\mathbf{P}$ \\
\hline & & B-28X-4, $85-87$ & C & G & . & . & . & . & . & . & . & . & $\mathbf{P}$ & . & . & . & . & . & + \\
\hline & & B-28X-CC & C & G & . & . & + & . & . & . & . & . & $\mathrm{P}$ & . & . & . & . & . & + \\
\hline & & B-29X-CC & C & G & . & . & . & . & . & . & . & . & $\mathbf{P}$ & . & . & . & . & . & + \\
\hline & D. petterssoni & B-30X-CC & C & G & . & . & . & . & . & . & . & . & $\mathbf{P}$ & . & . & . & . & . & . \\
\hline & & B-31X-4, 85-87 & C & G & . & . & . & . & . & . & . & . & $\mathbf{P}$ & . & . & . & . & . & . \\
\hline & & B-31X-CC & C & G & . & . & . & . & . & . & . & . & $\mathbf{P}$ & . & . & . & . & . & - \\
\hline & & B-32X-4, 85-87 & C & G & . & . & . & . & , & . & . & . & $\mathbf{P}$ & . & . & . & . & . & . \\
\hline & & B-32X-CC & C & G & . & . & . & . & . & . & . & . & - & . & . & . & . & . & . \\
\hline
\end{tabular}

Pterocanium prismatium Riedel. Riedel, 1957, p. 87, pl. 3, figs. 4, 5; emend. Riedel and Sanfilippo, 1970, p. 529.

Pterocorys campanula Haeckel. Haeckel, 1887, p. 1316, pl. 71, fig. 3; Caulet and Nigrini, 1988, p. 226, pl. 1, figs. 2-5.

Pterocorys hertwigii (Haeckel). Eucyrtidium hertwigii in Haeckel, 1887, p. 1491, pl. 80, fig. 12; Pterocorys hertwigii (Haeckel), in Nigrini, 1967 , p. 73 , pl. 7, figs. 4a, b and Caulet and Nigrini, 1988, p. 229, pl. 1, figs. 11-12.
Pterocorys minythorax (Nigrini). Theoconus minythorax in Nigrini, 1968, p. 57, pl. 1, fig. 8. Pterocorys minythorax (Nigrini) in Nigrini and Moore, 1979, p. N87, pl. 25, fig. 10 and Caulet and Nigrini, 1988, p. 231, pl. 2, fig. 6 .

Siphostichartus corona (Haeckel). Cyrtophormis (Acanthocyrtis) corona in Haeckel, 1887, p. 1462, pl. 77, fig. 15; Siphostichartus corona (Haeckel) in Nigrini, 1977, p. 257, pl. 2, figs. 5-7. 
Table 1 (continued).

\begin{tabular}{|c|c|c|c|c|c|c|c|c|c|c|c|c|c|c|c|c|c|c|c|c|c|c|c|}
\hline 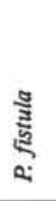 & 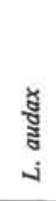 & 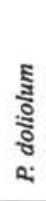 & 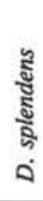 & $\begin{array}{l}\text { है } \\
\text { है } \\
\text { जे }\end{array}$ & 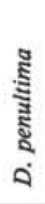 & $\begin{array}{l}\text { है } \\
\text { हूँ } \\
\text { ஸे }\end{array}$ & 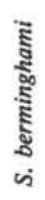 & 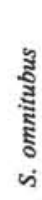 & 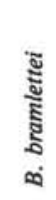 & 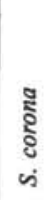 & 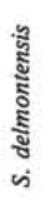 & 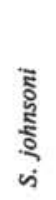 & 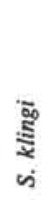 & 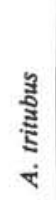 & 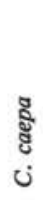 & $\begin{array}{l}\text { है } \\
\text { : } \\
\text { ¿ }\end{array}$ & 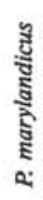 & 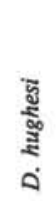 & 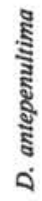 & 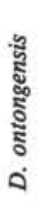 & 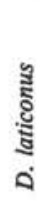 & 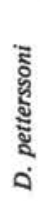 & 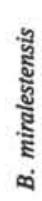 \\
\hline . & . & . & . & . & . & . & . & . & . & . & & . & ${ }^{\circ}$ & . & & . & . & . & . & & . & . & . \\
\hline : & . & . & . & . & . & . & . & . & . & . & . & . & . & . & & 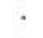 & 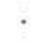 & . & . & & & & \\
\hline & $:$ & $:$ & $:$ & : & : & : & : & : & : & : & $:$ & : & : & $\dot{ }$ & . & : & $\cdot$ & · & $\cdot$ & $\cdot$ & & : & 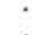 \\
\hline & . & . & . & . & . & . & . & : & $\therefore$ & : & $:$ & : & $:$ & : & & $:$ & ${ }^{\circ}$ & $:$ & : & $:$ & : & : & $:$ \\
\hline & $\cdot$ & . & $\cdot$ & . & $\cdot$ & . & $\cdot$ & . & . & . & . & . & . & . & 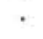 & . & . & . & . & . & . & . & . \\
\hline & $\dot{+}$ & $\because$ & $:$ & : & : & : & : & : & $\dot{+}$ & : & : & : & : & : & 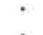 & $\cdot$ & + & : & $\cdot$ & : & i & . & \\
\hline & . & . & . & . & . & . & : & $:$ & . & : & $:$ & : & $\therefore$ & : & & $:$ & + & $:$ & $:$ & : & $:$ & $\dot{+}$ & . \\
\hline & $\cdot$ & . & $\cdot$ & $\cdot$ & $\cdot$ & . & & . & . & . & . & . & . & . & . & . & . & + & . & . & . & & . \\
\hline & $:$ & : & $:$ & : & : & : & : & : & : & . & . & : & : & . & & : & : & : & . & : & : & 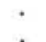 & : \\
\hline . & . & - & $\dot{ }$ & : & $\vdots$ & $:$ & $:$ & $:$ & : & : & $:$ & : & $:$ & 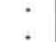 & & $:$ & : & : & $:$ & : & $i$ & $:$ & $:$ \\
\hline . & . & . & . & . & . & . & . & . & . & + & . & . & . & . & 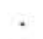 & . & ${ }^{\circ}$ & . & . & . & . & . & \\
\hline & $\dot{0}$ & $\cdot$ & $\cdot$ & $\cdot$ & . & . & $\cdot$ & . & . & $\dot{t}$ & + & + & . & . & & & ${ }^{\circ}$ & + & + & & + & + & . \\
\hline & $\dot{+}$ & $:$ & $:$ & $:$ & : & $:$ & $\vdots$ & $:$ & $:$ & $\stackrel{+}{+}$ & $\begin{array}{l}+ \\
+\end{array}$ & $\stackrel{+}{+}$ & : & $:$ & & + & : & $:$ & $:$ & : & : & $i$ & : \\
\hline- & - & - & + & . & . & . & : & + & : & + & + & . & : & : & $\cdot$ & . & . & + & . & 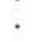 & . & & . \\
\hline$\vdots$ & $\dot{0}$ & + & $\cdot$ & $\cdot$ & $\cdot$ & . & $\cdot$ & . & $\cdot$ & . & + & $\cdot$ & . & . & . & + & . & $\cdot$ & . & & + & + & \\
\hline$\dot{-}$ & $\dot{-}$ & : & $:$ & : & : & $:$ & $:$ & : & : & : & ; & : & : & . & . & : & : & : & $\dot{+}$ & . & $\dot{+}$ & . & : \\
\hline$P$ & P & - & . & $\dot{-}$ & $\vdots$ & $\therefore$ & $\therefore$ & $:$ & $:$ & : & + & : & $:$ & 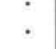 & & $:$ & $\cdot$ & + & 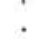 & 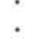 & + & + & \\
\hline$\stackrel{+}{\mathrm{P}}$ & $\begin{array}{l}\mathrm{P} \\
\mathrm{P}\end{array}$ & $\overline{\mathrm{P}}$ & : & $\overline{\mathrm{P}}$ & ; & . & $\cdot$ & . & . & . & $\cdot$ & + & . & 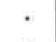 & 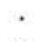 & . & + & . & ${ }^{\circ}$ & 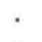 & 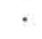 & 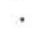 & \\
\hline${ }_{P}$ & ${ }_{\mathrm{P}}^{\mathrm{P}}$ & - & $:$ & 1 & $\underline{-}$ & $\dot{\mathrm{P}}$ & $:$ & : & . & : & $:$ & $\dot{0}$ & : & : & . & : & . & $:$ & $\dot{+}$ & . & : & + & + \\
\hline$P$ & $\mathbf{P}$ & $\mathbf{P}$ & $\because$ & + & $P$ & + & : & : & $\therefore$ & + & $\therefore$ & $\vdots$ & $:$ & $:$ & . & $:$ & : & : & . & : & : &. & : \\
\hline$P$ & $\overline{\mathrm{p}}$ & 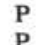 & + & + & $\mathrm{P}$ & i & . & ; & $\cdot$ & + & . & + & . & . & . & . & . & . & ${ }^{\circ}$ & . & 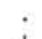 & . & . \\
\hline $\begin{array}{l}\mathrm{P} \\
\mathrm{P}\end{array}$ & $\begin{array}{l}\mathrm{P} \\
\mathrm{P}\end{array}$ & $\begin{array}{l}\mathrm{P} \\
\mathrm{P}\end{array}$ & : & $\begin{array}{l}\mathrm{P} \\
+\end{array}$ & $\begin{array}{l}\mathrm{P} \\
\mathrm{P}\end{array}$ & + & . & $?$ & . & . & - & . & . & . & , & . & + & · & . & . & + & . & \\
\hline & $\mathrm{P}$ & $P$ & - & $\mathbf{P}$ & ${ }_{\mathrm{P}}^{\mathrm{P}}$ & $i$ & : & $\dot{-}$ & $\dot{t}$ & - & . & : & . & : & & : & : & $\vdots$ & $\mathbf{P}$ & . & : & 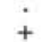 & : \\
\hline & $P$ & + & $P$ & - & $\mathrm{P}$ & . & . & $P$ & . & . & - & : & . & . & : & . & . & . & + & . & . & + & . \\
\hline$P$ & $\begin{array}{l}\mathbf{P} \\
+\end{array}$ & $\begin{array}{l}\mathrm{P} \\
\mathrm{P}\end{array}$ & $\mathrm{F}$ & \pm & $\begin{array}{l}\mathrm{P} \\
\mathrm{P}\end{array}$ & $\dot{+}$ & $\cdot$ & P & + & . & 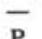 & i & . & . & & . & . & i & i & . & & & . \\
\hline $\begin{array}{l}\mathrm{P} \\
\mathrm{P}\end{array}$ & $\stackrel{+}{\mathrm{P}}$ & $\begin{array}{l}P \\
P\end{array}$ & $\mathrm{~F}$ & $\overline{\mathrm{P}}$ & $\begin{array}{l}\mathrm{P} \\
\mathrm{P}\end{array}$ & + & : & $\stackrel{+}{\mathrm{P}}$ & $\stackrel{+}{+}$ & : & F & + & : & : & & : & 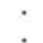 & \pm & + & ' & - & + & : \\
\hline & $P$ & $P$ & $F$ & - & $\mathrm{F}$ & + & . & $\mathbf{P}$ & . & . & 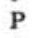 & : & $:$ & $:$ & . & + & : & + & + &. & . & 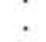 & ${ }^{\circ}$ \\
\hline & $\begin{array}{l}\mathrm{P} \\
\mathrm{P}\end{array}$ & $\begin{array}{l}\mathrm{P} \\
\mathrm{P}\end{array}$ & ${ }_{\mathrm{P}}^{\mathrm{P}}$ & $\mathrm{P}$ & $\mathrm{P}$ & . & $\cdot$ & $P$ & + & . & $\stackrel{+}{\mathbf{p}}$ & . & . & . & . & . & . & t & & $\cdot$ & & & \\
\hline & $\begin{array}{l}\mathrm{P} \\
\mathrm{P}\end{array}$ & $\underline{\mathbf{P}}$ & $\mathrm{F}$ & ${ }^{\mathrm{P}}$ & $\begin{array}{l}\mathrm{F} \\
\mathrm{F}\end{array}$ & : & : & $\underline{\mathbf{P}}$ & i & & 1 & $\dot{-}$ & $P$ & $\therefore$ & . & + & : & $\begin{array}{l}+ \\
+\end{array}$ & P & . & : & $\begin{array}{l}+ \\
+\end{array}$ & ${ }^{+}$ \\
\hline & $P$ & - & F & $\mathbf{P}$ & F & . & . & $P$ & - & - & P & - & . & - & $\therefore$ & $P$ & : & 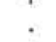 & + & $:$ & : & . & : \\
\hline P & $\begin{array}{l}\mathrm{P} \\
\mathrm{P}\end{array}$ & $\stackrel{P}{P}$ & $\mathrm{~F}$ & $P$ & $\mathrm{~F}$ & . & : & $P$ & 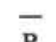 & + & & . & 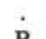 & . & . & 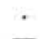 & . & + & 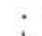 & ${ }^{\circ}$ &. & & . \\
\hline & $\begin{array}{l}\mathrm{P} \\
\mathrm{P}\end{array}$ & $\begin{array}{l}\mathrm{P} \\
\mathrm{P}\end{array}$ & $F$ & ${ }_{\mathrm{P}}^{\mathrm{P}}$ & $\mathrm{F}$ & . & + & $\mathrm{P}$ & $F$ & & P & - & $\mathbf{P}$ & -1 & & - & . & + & + & & & + & . \\
\hline & - & $P$ & $\mathrm{P}$ & $\mathrm{P}$ & 1 & : & 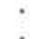 & $P$ & $\mathrm{P}$ & $\mathrm{F}$ & $t$ & $\bar{P}$ & 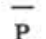 & 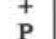 & & - & & $\cdot$ & + & & & & . \\
\hline P & + & $P$ & $\mathrm{P}$ & $\pi$ & $\mathrm{F}$ & . & $\therefore$ & $\mathrm{P}$ & . & 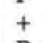 & & + & - & - & . & + & - & $\dot{+}$ & & . & & + & : \\
\hline & $\begin{array}{l}\mathrm{P} \\
\mathrm{P}\end{array}$ & $=$ & $\mathrm{P}$ & $\mathrm{P}$ & $F$ & . & 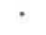 & $P$ & $\mathrm{P}$ & $\mathrm{F}$ & & $\mathbf{P}$ & & $\mathrm{F}$ & . & - & . & + & & . & * & + & . \\
\hline $\begin{array}{l}P \\
P\end{array}$ & $\mathrm{P}$ & $\overline{\mathrm{P}}$ & F & $P$ & 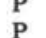 & • & . & $P$ & 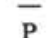 & P & & P & & & & & + & + & & & & & - \\
\hline- & $\mathbf{P}$ & $\mathbf{P}$ & $P$ & ? & $P$ & $\sigma^{\circ}$ & + & $P$ & $\mathrm{~F}$ & $P$ & 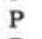 & - & & - & & . & & + & $\mathrm{F}$ & . & . & - & - \\
\hline & $\mathrm{P}$ & $\stackrel{P}{p}$ & & - & $F$ & . & & $\mathrm{P}$ & $\mathrm{P}$ & $\mathrm{F}$ & & $P$ & & & & 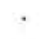 & & & & . & & & 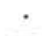 \\
\hline $\begin{array}{l}\mathrm{F} \\
\mathrm{P}\end{array}$ & $\begin{array}{l}\mathrm{P} \\
\mathrm{P}\end{array}$ & $\begin{array}{l}\mathrm{P} \\
\mathrm{P}\end{array}$ & ${ }_{P}^{P}$ & 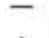 & ${ }_{\mathrm{P}}^{\mathrm{P}}$ & 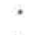 & $\mathrm{P}$ & $\mathbf{P}$ & $\mathrm{F}$ & & & & 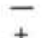 & & 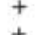 & $\pi$ & & & & & & & - \\
\hline & 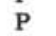 & $\mathrm{P}$ & $\mathrm{P}$ & $:$ & . & $\therefore$ & $\mathrm{P}$ & - & - & $\mathrm{F}$ & & $\mathbf{F}$ & 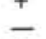 & . & & $\bar{P}$ & - & $\mathrm{P}$ & & : & + & & ${ }_{\mathrm{P}}^{+}$ \\
\hline $\mathbf{P}$ & $\mathbf{P}$ & P & $\mathrm{P}$ & . & - & $\sigma^{\circ}$ & $\mathrm{P}$ & . & $\mathrm{r}$ & $\mathrm{P}$ & & $\mathbf{P}$ & & . & & $P$ & & $r$ & & & & & n \\
\hline & $\mathbf{P}$ & $\mathrm{P}$ & $P$ & . & . & . & . & . & - & $\mathrm{p}$ & & $P$ & & . & & + & & $P$ & & + & & $F$ & $\mathbf{P}$ \\
\hline P & $\mathbf{P}$ & $\mathrm{P}$ & $P$ & . & . & . & . & . & + & $P$ & & $\mathrm{~F}$ & & & & $\mathbf{P}$ & & - & & 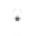 & & $\mathrm{P}$ & + \\
\hline & $=$ & $\begin{array}{l}\mathrm{P} \\
\mathrm{P}\end{array}$ & $P$ & : & . & . & . & . & - & $\begin{array}{l}\mathrm{P} \\
\mathrm{P}\end{array}$ & & & $\begin{array}{l}\mathrm{P} \\
\mathrm{P}\end{array}$ & & & & & - & 1 & 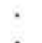 & & $P$ & $=$ \\
\hline & - & $\mathrm{P}$ & P & . & . & & . & . & & $\mathrm{P}$ & & - & $\mathrm{P}$ & & & & & . & & . & & P & $=$ \\
\hline$\stackrel{+}{\mathrm{P}}$ & $\stackrel{+}{\mathrm{P}}$ & $\begin{array}{l}\mathrm{P} \\
\mathrm{P}\end{array}$ & $\mathrm{P}$ & : & : & ; & : & 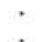 & $\mathrm{P}$ & $\mathbf{P}$ & & P & - & -1 & P & P & $P$ & : & P & . & $P$ & $P$ & - \\
\hline
\end{tabular}

Solenosphaera omnitubus Riedel and Sanfilippo. Riedel and Sanfilippo, 1971 , p. 1586, pl. 1A, fig. 24, pl. 4, figs. 1-2 (non pl. 1A, fig. 23). Spongaster berminghami (Campbell and Clark). Spongasteriscus berminghami in Campbell and Clark, 1944, p. 30, pl. 5, figs. 1-2; Spongaster klingi in Riedel and Sanfilippo, 1971, p. 1589, pl. 10, figs. 8-10, pl. 4, figs. 7-8; Spongaster berminghami (Campbell and Clark) in Riedel and Sanfilippo, 1978, p. 73, pl. 2, figs. 14-16.
Spongaster pentas Riedel and Sanfilippo. Riedel and Sanfilippo, 1970, p. 523 , pl. 15 , fig. 3 .

Spongaster tetras Ehrenberg tetras Nigrini. Ehrenberg, 1860, p. 833; 1872 b, p. 299 , pl. IV (iii), fig. 8 ; Nigrini, 1967 , p. 41 , pl. 5, figs. 1a, b.

Spongodiscus ambus Sanfilippo and Riedel. Sanfilippo and Riedel, 1974, p. 1024, pl. 1, figs. 12-14. 


\begin{tabular}{|c|c|c|c|c|c|c|c|c|c|c|c|c|c|c|c|c|c|c|c|c|}
\hline Age & $\begin{array}{l}\text { Radiolarian } \\
\text { zone }\end{array}$ & Sample & 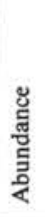 & 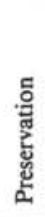 & 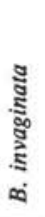 & 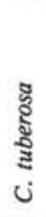 & 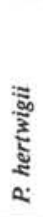 & 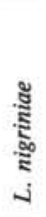 & 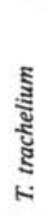 & 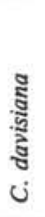 & 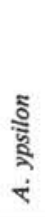 & 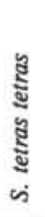 & 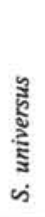 & 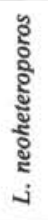 & 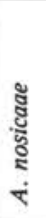 & 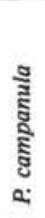 & 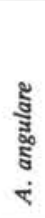 & 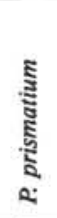 & 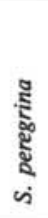 & ${ }_{0}^{\stackrel{0}{3}}$ \\
\hline \multirow{10}{*}{ Quaternary } & C. tuberosa & $\begin{array}{l}\text { A-1H-2, 85-87 } \\
\text { A-1H-CC }\end{array}$ & $\begin{array}{l}\mathrm{C} \\
\mathrm{C}\end{array}$ & $\begin{array}{l}M \\
G\end{array}$ & + & $\bar{P}$ & $\overline{\mathrm{P}}$ & $\begin{array}{l}\mathrm{P} \\
\mathrm{P}\end{array}$ & $\bar{t}$ & $\stackrel{+}{\mathrm{P}}$ & $\begin{array}{l}\mathrm{P} \\
\mathrm{P}\end{array}$ & $\begin{array}{l}\mathrm{P} \\
\mathrm{P}\end{array}$ & $\begin{array}{l}\mathrm{P} \\
\mathrm{P}\end{array}$ & . & . & $\dot{.}$ & $\dot{.}$ & $\dot{.}$ & $\dot{.}$ & : \\
\hline & \multirow{7}{*}{ A. ypsilon } & A- $2 \mathrm{H}-4,85-87$ & C & G & . & - & - & $\mathrm{P}$ & + & $\mathrm{P}$ & $\mathrm{P}$ & $\mathrm{P}$ & $\mathrm{P}$ & : & . & . & . & : & : & . \\
\hline & & A- $2 \mathrm{H}-\mathrm{CC}$ & C & G & . & - & $\mathbf{P}$ & $\mathbf{P}$ & $P$ & $\mathbf{P}$ & $\mathbf{P}$ & P & 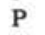 & . & . & . & . & . & . & . \\
\hline & & A-3H- $-4,85-87$ & C & G & . & . & $\mathrm{P}$ & $\mathbf{P}$ & - & $\mathrm{P}$ & $\mathbf{P}$ & $\mathbf{P}$ & $\mathrm{P}$ & - & . & + & - & . & . & . \\
\hline & & $\mathrm{A}-3 \mathrm{H}-\mathrm{CC}$ & C & G & . & . & - & $\mathbf{P}$ & $\mathbf{P}$ & $\mathbf{P}$ & $\mathbf{P}$ & $\mathbf{P}$ & $\mathrm{P}$ & + & . & + & $?$ & . & . & . \\
\hline & & A-4H-4, 85-87 & $\mathbf{F}$ & M & . & . & . & + & - & $\mathbf{P}$ & + & $\mathbf{P}$ & $\mathbf{P}$ & - & - & - & - & . & + & . \\
\hline & & A- $4 \mathrm{H}-\mathrm{CC}$ & $\mathbf{F}$ & M & . & . & . & + & + & $\mathbf{P}$ & $\mathbf{P}$ & $\mathbf{P}$ & $\mathbf{P}$ & + & - & - & - & - & + & . \\
\hline & & A-5H-4, 85-87 & $\mathbf{F}$ & M & . & . & . & - & - & $P$ & - & $\mathbf{P}$ & $\mathbf{P}$ & $\mathbf{P}$ & - & - & $\bar{x}$ & - & . & . \\
\hline & \multirow{2}{*}{ A. angulare } & $\begin{array}{l}\text { A-5H-CC } \\
\text { A- } 6 \mathrm{H}-4,85-87\end{array}$ & $\begin{array}{l}\mathrm{C} \\
\mathrm{C}\end{array}$ & $\begin{array}{l}G \\
G\end{array}$ & : & : & $\dot{.}$ & - & $\underline{P}$ & $\begin{array}{l}\mathrm{P} \\
\mathrm{P}\end{array}$ & $\begin{array}{l}\mathrm{P} \\
\mathrm{P}\end{array}$ & & $\begin{array}{l}\mathrm{P} \\
\mathrm{P}\end{array}$ & $\begin{array}{l}\mathrm{P} \\
\mathrm{P}\end{array}$ & $\begin{array}{l}P \\
P\end{array}$ & $\begin{array}{l}\mathrm{P} \\
\mathrm{P}\end{array}$ & $\begin{array}{l}\mathrm{P} \\
\mathrm{P}\end{array}$ & $\bar{z}$ & i & . \\
\hline & & A-6H-CC & $\mathrm{C}$ & G & : & : & $\dot{.}$ & $\dot{.}$ & $\overline{-}$ & $\begin{array}{l}\mathrm{P} \\
\mathrm{P}\end{array}$ & $P$ & $P$ & $\begin{array}{l}\mathrm{P} \\
\mathrm{P}\end{array}$ & $\begin{array}{l}\mathrm{P} \\
\mathrm{P}\end{array}$ & $\begin{array}{l}\mathrm{P} \\
\mathrm{P}\end{array}$ & $\begin{array}{l}\mathrm{P} \\
\mathrm{P}\end{array}$ & $\begin{array}{l}\mathrm{P} \\
\mathrm{P}\end{array}$ & $\bar{t}$ & $\begin{array}{l}+ \\
+\end{array}$ & $\dot{.}$ \\
\hline \multirow{22}{*}{ Pliocene } & \multirow{4}{*}{ P. prismatium } & A-7H-4, 80-82 & C & G & . & . & . & . & - & $P$ & - & $P$ & $\mathbf{P}$ & $\mathbf{P}$ & - & - & - & + & . & . \\
\hline & & A-7H-CC & C & G & . & . & . & . & - & $\mathbf{P}$ & $\mathrm{P}$ & $P$ & $\mathbf{P}$ & + & $P$ & - & - & + & - & + \\
\hline & & A- $8 \mathrm{H}-4,85-87$ & C & G & . & . & . & . & - & $\mathbf{P}$ & $\mathbf{P}$ & $\mathbf{P}$ & $\mathbf{P}$ & - & $\mathbf{P}$ & - & . & - & + & . \\
\hline & & A-8H-CC & C & G & . & . & . & . & - & $\mathbf{P}$ & $\mathrm{P}$ & $\mathbf{P}$ & $\mathbf{P}$ & $\mathbf{P}$ & $\mathrm{P}$ & - & . & - & + & . \\
\hline & & A-9H-CC & $\mathbf{F}$ & M & . & . & . & . & - & - & + & - & $\mathbf{P}$ & + & - & - & . & - & $\mathbf{P}$ & . \\
\hline & & A-10X-4, 85-87 & F & G & . & . & . & . & . & + & $P$ & $\mathrm{P}$ & $\mathbf{P}$ & - & + & . & . & + & $\mathbf{P}$ & . \\
\hline & & A-10X-CC & $\mathrm{F}$ & G & . & . & . & . & . & - & - & $\mathbf{P}$ & $\mathbf{P}$ & - & - & - & . & $\mathbf{P}$ & $\mathbf{P}$ & - \\
\hline & & A-11X-4, 85-87 & c & G & . & . & . & . & . & . & $\mathbf{P}$ & P & $\mathbf{P}$ & . & + & . & . & - & $\mathbf{P}$ & - \\
\hline & & A-11X-CC & C & G & . & . & . & . & . & . & + & $\mathbf{P}$ & $\mathbf{P}$ & - & $\mathbf{P}$ & + & . & $\mathbf{P}$ & $\mathbf{P}$ & + \\
\hline & & A-12X-4, 85-87 & C & G & . & . & . & . & . & . & - & $P$ & $\mathbf{P}$ & . & $\mathbf{P}$ & . & . & - & $\mathbf{P}$ & $\mathbf{P}$ \\
\hline & S. pentas & $A-12 X-C C$ & C & G & . & . & . & . & . & . & . & $P$ & $\mathrm{P}$ & - & $\mathbf{P}$ & + & . & $\mathbf{P}$ & $\mathbf{P}$ & $\mathbf{P}$ \\
\hline & & A-13X-4, 85-87 & C & G & . & . & . & . & . & . & . & - & $\mathbf{P}$ & . & + & . & . & $?$ & $\mathbf{P}$ & $\mathbf{P}$ \\
\hline & & A-13X-CC & C & G & . & . & . & . & . & . & . & - & $\mathbf{P}$ & . & $\mathbf{P}$ & $\mathbf{P}$ & . & - & $\mathbf{P}$ & $\mathbf{P}$ \\
\hline & & A-14X-4, 85-87 & C & $\mathrm{M}$ & . & . & . & . & . & . & . & . & $\mathbf{P}$ & . & $\mathbf{P}$ & . & . & . & $\mathbf{P}$ & + \\
\hline & & A-14X-CC & C & G & . & . & . & . & . & . & . & . & $\mathbf{P}$ & . & $\mathbf{P}$ & . & . & . & $\mathbf{P}$ & - \\
\hline & & A-15X-4, $85-87$ & C & G & . & . & . & . & . & . & . & . & $\mathbf{P}$ & . & $\mathbf{P}$ & . & . & . & $\mathbf{P}$ & + \\
\hline & & A-15X-CC & C & G & . & . & . & . & . & . & . & . & $\mathbf{P}$ & . & P & + & . & . & $\mathrm{P}$ & - \\
\hline & & A-16X-CC & C & G & . & . & . & . & . & . & . & . & $\mathbf{P}$ & . & $\mathbf{P}$ & . & . & . & $\mathbf{P}$ & $\mathbf{P}$ \\
\hline & & A-17X-2, 86-88 & C & $\mathrm{M}$ & . & . & . & . & . & . & . & . & $\mathrm{P}$ & . & $P$ & . & . & . & $\mathbf{P}$ & $\mathbf{P}$ \\
\hline & & A-17X-CC & C & G & . & . & . & . & . & . & . & . & $\mathbf{P}$ & . & - & . & . & . & $\mathbf{P}$ & $\mathbf{P}$ \\
\hline & & A-18X-2, 85-87 & C & G & . & . & . & . & . & . & . & . & $\mathrm{P}$ & . & $\mathbf{P}$ & + & . & . & $\mathbf{P}$ & + \\
\hline & & A-18X-CC & C & G & . & . & . & . & . & . & . & . & $\mathbf{P}$ & . & $\mathbf{P}$ & . & . & . & $\mathbf{P}$ & $\mathbf{P}$ \\
\hline & $S$, peregring & A-19X-4, 85-87 & C & G & . & . & . & . & . & . & . & . & $\mathbf{P}$ & . & $\mathbf{P}$ & . & . & . & $\mathbf{P}$ & $\mathbf{P}$ \\
\hline & 3. peregrina & A-19X-CC & C & G & . & . & . & . & . & . & . & . & $\mathbf{P}$ & . & $\mathbf{P}$ & . & . & . & $\mathbf{P}$ & $\mathbf{P}$ \\
\hline & & A-20X-4, 85-87 & C & G & . & . & . & . & . & . & . & . & $\mathbf{P}$ & . & $\mathbf{P}$ & + & . & . & $\mathbf{P}$ & $\mathbf{P}$ \\
\hline & & A-20X-CC & C & G & . & . & . & . & . & . & . & . & $\mathbf{P}$ & . & $P$ & . & . & . & $\mathbf{P}$ & $\mathbf{P}$ \\
\hline & & A-21X-CC & C & G & . & . & . & . & . & . & . & . & $\mathbf{P}$ & . & $\mathbf{P}$ & . & . & . & $\mathbf{P}$ & $\mathbf{P}$ \\
\hline & & A- $22 X-4,85-87$ & C & G & . & . & . & . & . & . & . & . & $\mathrm{P}$ & . & $\mathbf{P}$ & . & . & . & $\mathbf{P}$ & $\mathbf{P}$ \\
\hline & & $A-22 X-C C$ & c & G & . & . & . & . & . & . & . & . & $\mathbf{P}$ & . & - & . & . & . & $\mathbf{P}$ & $\mathbf{P}$ \\
\hline & & A- $-23 X-4,85-87$ & C & G & . & . & . & . & . & . & . & . & $\mathrm{P}$ & . & + & . & . & . & $\mathbf{P}$ & $\mathbf{P}$ \\
\hline & & A-23X-CC & C & G & . & . & . & . & . & . & . & . & $\mathbf{P}$ & . & $\mathbf{P}$ & . & . & . & $\mathrm{P}$ & $\mathbf{P}$ \\
\hline & D. penultima & A- $24 X-4,85-87$ & C & G & . & . & . & . & . & . & . & . & $\mathbf{P}$ & . & $\mathbf{P}$ & . & . & . & $\mathbf{P}$ & $\mathbf{P}$ \\
\hline & & A-24X-CC & C & G & . & . & . & . & . & . & . & . & $\mathrm{P}$ & . & $P$ & . & . & . & $\mathbf{P}$ & P \\
\hline & & A-25X-CC & C & G & . & . & . & . & . & . & . & . & $P$ & . & - & . & . & . & $\mathbf{P}$ & $\mathbf{P}$ \\
\hline & & A-26X-CC & C & G & . & . & . & . & . & . & . & . & $\mathbf{P}$ & . & - & . & . & . & - & + \\
\hline & & A-27X-4, 80-82 & C & G & . & . & . & . & . & . & . & . & $\mathbf{P}$ & . & + & . & . & . & . & $\overline{-}$ \\
\hline & & A-27X-CC & C & G & . & . & . & . & . & . & . & . & $\mathbf{P}$ & . & + & $\mathbf{P}$ & . & . & . & $\mathbf{P}$ \\
\hline & & A-28X-CC & C & G & . & . & . & . & . & . & . & . & $\mathbf{P}$ & . & + & . & . & . & + & $\mathbf{P}$ \\
\hline Miocene & D. antepenultima & A-29X-CC & C & G & . & . & . & . & . & . & . & . & $\mathbf{P}$ & . & . & . & . & . & + & $\mathbf{P}$ \\
\hline & & B-28X-CC & C & G & . & . & . & . & . & . & . & . & $\mathbf{P}$ & . & . & . & . & . & . & $\mathbf{P}$ \\
\hline & & B-29X-4, 85-87 & C & G & . & . & . & . & . & . & . & . & $\mathbf{P}$ & . & + & . & . & . & . & $\mathbf{P}$ \\
\hline & & B-29X-CC & C & G & . & . & . & . & . & . & . & . & $\mathbf{P}$ & . & . & . & . & . & . & + \\
\hline & & B-30X-CC & C & G & . & . & . & . & . & . & . & . & $\mathbf{P}$ & . & . & . & . & . & . & $\mathbf{P}$ \\
\hline & & B-31X-4, 85-87 & C & G & . & . & . & . & . & . & . & . & $\mathbf{P}$ & . & . & . & . & . & . & $\mathbf{P}$ \\
\hline & & B-31X-CC & C & G & . & . & . & . & . & . & . & . & $\mathbf{P}$ & . & . & . & . & . & . & $\mathbf{P}$ \\
\hline & & B-32X-4, 85-87 & C & M & . & . & . & . & . & . & . & . & $\mathrm{P}$ & . & . & + & . & . & . & + \\
\hline & & B-32X-CC & C & G & . & . & . & . & . & . & . & . & $\mathbf{P}$ & . & . & . & . & . & . & $\mathbf{P}$ \\
\hline & & B-33X-CC & C & G & . & . & . & . & . & . & . & . & $\mathbf{P}$ & . & . & . & . & . & . & $\mathbf{P}$ \\
\hline & & B-34X-CC & C & G & . & . & . & . & . & . & . & . & $\mathbf{P}$ & . & . & . & . & . & . & $\mathbf{P}$ \\
\hline & & B-35X-4, 85-87 & C & G & . & . & . & . & . & . & . & . & + & . & . & . & . & . & . & $\mathbf{P}$ \\
\hline & D. petterssoni & B-35X-CC & C & G & . & . & . & . & . & . & . & . & $P$ & . & . & . & . & . & . & - \\
\hline & & B-36X-4, 85-87 & C & M & . & . & . & . & . & . & . & . & $P$ & . & . & . & . & . & . & $\mathbf{P}$ \\
\hline & & B-36X-CC & F & M & . & . & . & . & . & . & . & . & $\mathbf{P}$ & . & . & . & . & - & . & - \\
\hline & & B-37X-4, 85-87 & $\mathrm{F}$ & M & . & . & . & . & . & . & . & . & $\mathbf{P}$ & . & . & . & . & . & . & $\mathbf{P}$ \\
\hline & & B-37X-CC & C & G & . & . & . & . & . & . & . & . & $\mathbf{P}$ & . & . & . & . & . & . & + \\
\hline & & B-38X-4, 85-87 & $F$ & G & . & . & . & . & . & . & . & . & $\mathbf{P}$ & . & . & . & . & . & . & $\mathbf{P}$ \\
\hline & & B-38X-CC & C & G & . & . & . & . & . & . & . & . & $\mathbf{P}$ & . & . & . & . & . & $\cdot$ & $?$ \\
\hline
\end{tabular}




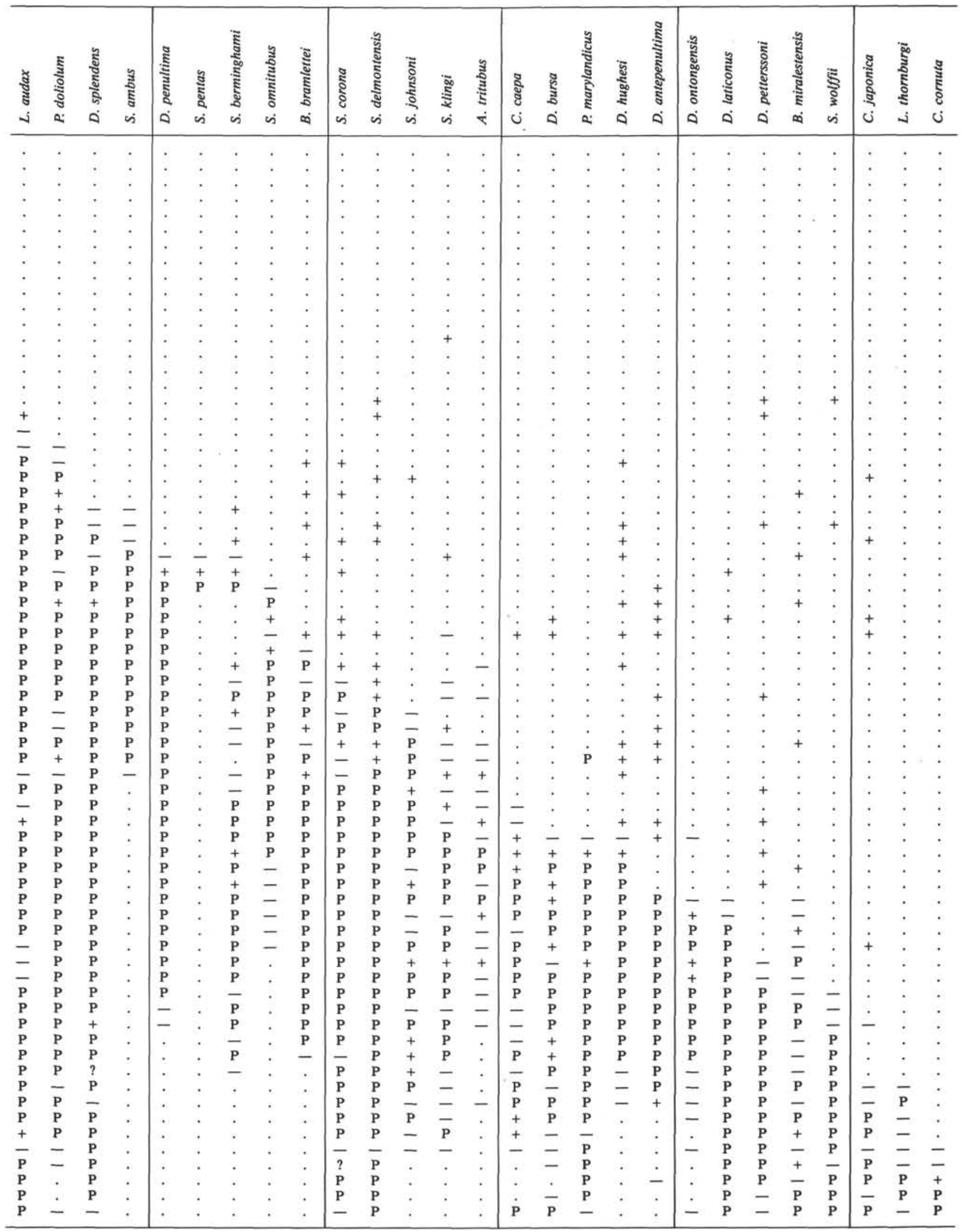




\section{NIGRINI}

Spongodiscus klingi Caulet. Caulet, 1986, p. 849, pl. 2, figs. 1a, b. Stichocorys delmontensis (Campbell and Clark). Eucyrtidium delmontensis in Campbell and Clark, 1944, p. 56, pl. 7, figs. 19, 20; Stichocorys delmontensis (Campbell and Clark) in Sanfilippo and Riedel, 1970 , p. 451 , pl. 1, fig. 9.

Stichocorys johnsoni Caulet. Caulet, 1986, p. 851, pl. 6, figs. 5-6.

Stichocorys peregrina (Riedel). Eucyrtidium elongatum peregrinum in Riedel, 1953, p. 812, pl. 85, fig. 2; Stichocorys peregrina (Riedel) in Sanfilippo and Riedel, 1970, p. 451, pl. 1, fig. 10.

Stichocorys wolffii Haeckel. Haeckel, 1887, p. 1479, pl. 80, fig. 10.
Streblacantha circumtexta (Jörgensen). Sorolarcus circumtextus in Jörgensen, 1900, p. 65; Streblacantha circumtexta (Jörgensen) in Jörgensen, 1905, p. 121, pl. 11, 12, fig. 46.

Stylatractus universus Hays. Hays, 1970, p. 215, pl. 1, figs. 1, 2.

Tetrapyle octacantha Müller. Müller, 1858, p. 33, pl. 2, figs. 12, 13, pl. 3, figs. 1-12; Benson, 1966, p. 245, pl. 15, figs. 3-10, pl. 16, fig. 1, text-fig. 18.

Theocorythium trachelium (Ehrenberg). Eucyrtidium trachelius in Ehrenberg, 1872a, p. 312; Theocorythium trachelium (Ehrenberg) trachelium Nigrini in Nigrini, 1967, p. 79, pl. 8, fig. 2, pl. 9, fig. 2.

Table 3. Raw data for stratigraphically important species in Hole 723A.

\begin{tabular}{|c|c|c|c|c|c|c|c|c|c|c|c|c|c|c|c|c|c|c|}
\hline Age & $\begin{array}{c}\text { Radiolarian } \\
\text { zone }\end{array}$ & Sample & 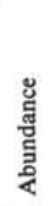 & 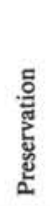 & 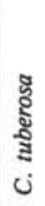 & $\frac{\square}{2}$ & 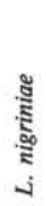 & 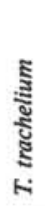 & 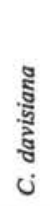 & $\begin{array}{l}\text { క } \\
\frac{\hbar}{2} \\
\frac{\pi}{\pi}\end{array}$ & 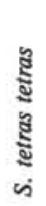 & 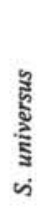 & 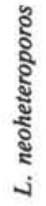 & 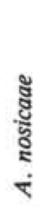 & 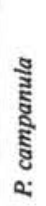 & $\begin{array}{l}\text { కूँ } \\
\text { ปี้ } \\
\text { కี } \\
\text { षं }\end{array}$ & 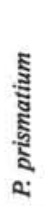 & 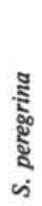 \\
\hline \multirow{34}{*}{ Quaternary } & \multirow{34}{*}{ Unzoned } & $1 \mathrm{H}-\mathrm{CC}$ & $\mathbf{R}$ & G & - & - & - & - & - & - & - & - & - & - & - & - & - & - \\
\hline & & $2 \mathrm{H}-\mathrm{CC}$ & - & - & - & - & - & - & - & - & - & - & - & - & - & - & - & - \\
\hline & & $3 \mathrm{H}-4,85-87$ & - & - & - & - & - & - & - & - & - & - & - & - & - & - & - & - \\
\hline & & $3 \mathrm{H}-\mathrm{CC}$ & $\mathbf{R}$ & G & . & . & $\mathbf{P}$ & . & . & $P$ & . & . & . & . & . & . & . & . \\
\hline & & $4 \mathrm{H}-4,85-87$ & - & - & - & - & - & - & - & - & - & - & - & - & - & - & - & - \\
\hline & & $4 \mathrm{H}-\mathrm{CC}$ & $\mathbf{R}$ & G & . & . & $?$ & . & . & . & . & . & . & . & . & . & . & . \\
\hline & & $5 \mathrm{H}-4,85-87$ & $\mathbf{R}$ & M & - & - & - & - & - & - & - & - & - & - & - & - & - & + \\
\hline & & SH-CC & C & G & $?$ & $\mathbf{P}$ & $\mathbf{P}$ & - & $\mathbf{P}$ & $\mathbf{P}$ & $\mathbf{P}$ & - & - & $\mathbf{P}$ & - & - & - & - \\
\hline & & $6 \mathrm{H}-\mathrm{CC}$ & $\mathbf{R}$ & G & . & . & . & . & . & . & . & . & . & . & . & . & . & . \\
\hline & & $7 \mathrm{H}-\mathrm{CC}$ & - & - & - & - & - & - & - & - & - & - & - & - & - & - & - & - \\
\hline & & $8 \mathrm{H}-\mathrm{CC}$ & $\mathbf{R}$ & $\mathbf{M}$ & . & . & . & . & $\mathbf{P}$ & . & $?$ & . & . & . & . & . & . & . \\
\hline & & $9 \mathrm{H}-4,85-87$ & $\mathrm{C}$ & $\mathbf{M}$ & - & - & - & - & - & $\mathbf{P}$ & $\mathbf{P}$ & $\mathrm{P}$ & $\mathbf{P}$ & - & - & - & - & - \\
\hline & & $9 \mathrm{H}-\mathrm{CC}$ & - & - & - & - & - & - & - & - & - & - & - & - & - & - & - & - \\
\hline & & $11 \mathrm{X}-\mathrm{CC}$ & - & - & - & - & - & - & - & - & - & - & - & - & - & - & - & - \\
\hline & & $13 \mathrm{X}-\mathrm{CC}$ & - & - & - & - & - & - & - & - & - & - & - & - & - & - & - & - \\
\hline & & $14 \mathrm{X}-\mathrm{CC}$ & - & - & - & - & - & - & - & - & - & - & - & - & - & - & - & - \\
\hline & & $15 X-4,85-87$ & $\mathbf{R}$ & M & . & . & $\cdot$ & $\therefore$ & $\therefore$ & . & . & $\cdot$ & $\cdot$ & . & . & $\cdot$ & . & . \\
\hline & & $15 \mathrm{X}-\mathrm{CC}$ & F & G & . & . & . & $?$ & $\mathbf{P}$ & . & . & . & . & + & . & . & . & . \\
\hline & & 17X-CC & $\mathbf{R}$ & $\mathbf{M}$ & . & . & . & . & . & . & . & . & . & . & . & . & . & . \\
\hline & & 19X-CC & $\mathbf{R}$ & $\mathbf{P}$ & . & . & . & . & . & . & . & . & . & . & . & . & . & . \\
\hline & & $20 \mathrm{X}-\mathrm{CC}$ & $\mathbf{R}$ & $\mathbf{P}$ & . & . & . & . & . & . & . & . & . & . & . & . & . & . \\
\hline & & 21X-CC & $\mathbf{R}$ & $\mathbf{P}$ & . & . & . & . & . & . & . & . & . & . & . & . & . & . \\
\hline & & $22 X-4,85-87$ & $\mathbf{F}$ & G & . & . & . & . & + & $\mathbf{P}$ & . & . & . & . & . & . & . & . \\
\hline & & $22 \mathrm{X}-\mathrm{CC}$ & $\mathbf{F}$ & G & . & . & . & - & . & + & + & . & . & . & . & + & . & . \\
\hline & & $23 \times-2,59-61$ & $\mathbf{F}$ & G & . & . & . & . & . & . & . & . & - & . & - & · & . & . \\
\hline & & $23 \mathrm{X}-\mathrm{CC}$ & $\mathrm{F}$ & G & . & . & . & . & $\therefore$ & . & $\therefore$ & $\dot{0}$ & $\dot{x}$ & $\therefore$ & . & $\dot{x}$ & . & . \\
\hline & & $24 X-4,85-87$ & C & M & . & . & . & . & $\mathbf{P}$ & . & $\mathbf{P}$ & $\mathbf{P}$ & $\mathbf{P}$ & $\mathbf{P}$ & . & $\mathbf{P}$ & . & . \\
\hline & & $24 \mathrm{X}-\mathrm{CC}$ & F & G & . & . & . & . & $\mathrm{P}$ & + & + & - & $\mathrm{P}$ & . & . & . & . & . \\
\hline & & $25 \mathrm{X}-\mathrm{CC}$ & - & - & - & - & - & - & - & - & - & - & - & - & - & - & - & - \\
\hline & & $26 \mathrm{X}-\mathrm{CC}$ & $\mathbf{R}$ & $\mathbf{P}$ & . & . & . & . & . & . & . & . & . & . & . & . & . & . \\
\hline & & $27 \mathrm{X}-\mathrm{CC}$ & - & - & - & - & - & - & - & - & - & - & - & - & - & - & - & - \\
\hline & & $28 \mathrm{X}-\mathrm{CC}$ & $\mathbf{R}$ & $\mathbf{P}$ & . & . & . & . & . & $\dot{.}$ & . & $\therefore$ & . & . & . & . & . & . \\
\hline & & $29 X-4,85-87$ & F & $\mathbf{M}$ & . & . & . & . & $\mathbf{P}$ & $\mathbf{P}$ & $\mathbf{P}$ & $\mathbf{P}$ & $\mathbf{P}$ & . & . & . & . & . \\
\hline & & $29 \mathrm{X}-\mathrm{CC}$ & F & G & . & . & . & . & $\mathbf{P}$ & . & . & . & $\mathbf{P}$ & . & . & . & . & . \\
\hline \multirow{8}{*}{--} & & $30 \mathrm{X}-\mathrm{CC}$ & $\mathbf{R}$ & $\mathbf{M}$ & . & . & . & . & . & . & . & . & . & . & . & . & . & . \\
\hline & & $31 \mathrm{X}-\mathrm{CC}$ & $\mathbf{R}$ & G & . & . & . & . & . & . & . & . & . & . & - & . & . & $\cdot$ \\
\hline & & $32 X-4,86-88$ & F & $\mathbf{P}$ & . & . & . & . & $\therefore$ & . & . & . & . & . & . & . & . & . \\
\hline & & $32 \mathrm{X}-\mathrm{CC}$ & F & G & . & . & . & . & $\mathbf{P}$ & . & . & . & . & . & . & . & . & . \\
\hline & & $33 \times-4,12-14$ & F & $\mathrm{M}$ & . & . & . & . & $\mathbf{P}$ & . & . & $\mathrm{P}$ & $\mathbf{P}$ & . & . & . & . & . \\
\hline & & $33 \mathrm{X}-\mathrm{CC}$ & C & G & . & . & . & . & $\mathbf{P}$ & + & $\mathbf{P}$ & - & - & $\mathbf{P}$ & . & . & . & . \\
\hline & & $34 X-C C$ & C & $\mathrm{M}$ & . & . & . & . & $\mathbf{P}$ & . & $\mathrm{P}$ & . & $\mathbf{P}$ & $\mathrm{P}$ & . & . & . & . \\
\hline & & $35 X-4,85-87$ & C & $\mathbf{M}$ & . & . & . & . & $\mathbf{P}$ & + & $\mathbf{P}$ & $\mathbf{P}$ & . & . & . & . & - & . \\
\hline \multirow{10}{*}{ Pliocene } & \multirow{10}{*}{$P$ prismatium } & $35 \mathrm{X}-\mathrm{CC}$ & C & G & . & . & . & . & $\mathbf{P}$ & . & $\cdot$ & $\mathbf{P}$ & + & $\mathbf{P}$ & . & . & $\mathbf{P}$ & . \\
\hline & & $36 \times-4,69-71$ & $\mathbf{R}$ & P & . & . & . & . & $\mathrm{P}$ & - & + & $\dot{x}$ & . & . & . & . & . & · \\
\hline & & $36 \mathrm{X}-\mathrm{CC}$ & C & G & . & . & . & . & $\mathbf{P}$ & + & P & $\mathbf{P}$ & . & $\dot{0}$ & . & . & . & . \\
\hline & & $37 \mathrm{X}-\mathrm{CC}$ & $\mathrm{C}$ & G & . & . & . & + & - & $\mathbf{P}$ & $P$ & - & . & $\mathrm{P}$ & . & . & + & . \\
\hline & & $39 X-4,85-87$ & - & - & - & - & - & - & - & - & - & - & - & - & - & - & - & - \\
\hline & & $39 \mathrm{X}-\mathrm{CC}$ & $\mathbf{R}$ & $\mathbf{M}$ & - & - & - & - & - & - & - & - & - & - & - & - & - & - \\
\hline & & $40 X-4,64-66$ & $\mathrm{~F}$ & $\mathbf{P}$ & . & . & . & . & $\mathbf{P}$ & . & . & $P$ & $\cdot$ & . & $\cdot$ & . & . & . \\
\hline & & $40 \mathrm{X}-\mathrm{CC}$ & $\mathrm{F}$ & G & . & . & . & . & - & . & . & $\mathrm{P}$ & + & , & . & . & . & . \\
\hline & & $41 X-C C$ & C & G & . & . & . & . & - & + & $\mathrm{P}$ & $\mathrm{P}$ & $\mathbf{P}$ & . & . & . & . & . \\
\hline & & $42 \mathrm{X}-\mathrm{CC}$ & $\mathrm{C}$ & G & . & . & . & . & - & + & $\mathbf{P}$ & $\mathrm{P}$ & $\mathbf{P}$ & + & . & . & . & . \\
\hline
\end{tabular}

-* - denotes Pliocene-Pleistocene boundary based on nannofossil data. For explanation of symbols see Appendix A introduction. 
Table 4. Raw data for stratigraphically important species in Hole 724B. For explanation of symbols see Appendix A introduction.

\begin{tabular}{|c|c|c|c|c|c|c|c|c|c|c|c|c|}
\hline Age & $\begin{array}{l}\text { Radiolarian } \\
\text { zone }\end{array}$ & Sample & 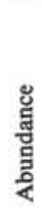 & 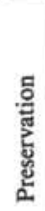 & 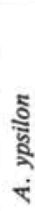 & 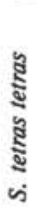 & 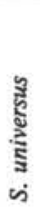 & 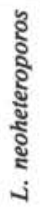 & 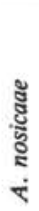 & 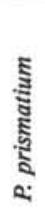 & 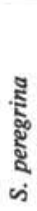 & 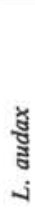 \\
\hline \multirow{16}{*}{ Age } & \multirow{16}{*}{ Barren } & $1 \mathrm{H}-\mathrm{CC}$ & - & - & . & . & . & . & . & . & . & . \\
\hline & & $2 \mathrm{H}-\mathrm{CC}$ & - & - & . & . & . & . & . & . & . & . \\
\hline & & $3 \mathrm{H}-\mathrm{CC}$ & - & - & . & . & . & . & . & . & . & . \\
\hline & & $4 \mathrm{H}-\mathrm{CC}$ & - & - & . & , & . & . & . & . & . & . \\
\hline & & $5 \mathrm{H}-\mathrm{CC}$ & - & - & . & . & . & . & . & . & . & . \\
\hline & & $6 \mathrm{X}-\mathrm{CC}$ & - & - & . & . & . & . & . & . & . & . \\
\hline & & 7X-CC & $\mathbf{R}$ & G & . & . & . & . & . & . & . & . \\
\hline & & $8 \mathrm{X}-\mathrm{CC}$ & $\mathbf{R}$ & G & . & . & . & . & . & . & . & . \\
\hline & & 9X-CC & - & - & . & . & . & . & . & . & . & . \\
\hline & & $10 \mathrm{X}-\mathrm{CC}$ & - & - & . & . & . & . & . & . & . & . \\
\hline & & $11 \mathrm{X}-\mathrm{CC}$ & R & G & . & . & . & . & . & . & . & . \\
\hline & & $12 \mathrm{X}-\mathrm{CC}$ & - & - & . & . & . & . & . & . & . & . \\
\hline & & $14 \mathrm{X}-\mathrm{CC}$ & $\mathbf{R}$ & M & . & . & . & . & . & . & . & . \\
\hline & & $15 \mathrm{X}-\mathrm{CC}$ & $\mathrm{R}$ & $\mathrm{P}$ & . & . & . & . & . & . & . & . \\
\hline & & $16 \mathrm{X}-\mathrm{CC}$ & - & - & . & . & . & . & . & . & . & . \\
\hline & & $17 \mathrm{X}-\mathrm{CC}$ & $\mathbf{R}$ & $\mathbf{P}$ & . & . & . & . & . & . & . & . \\
\hline \multirow{10}{*}{ Pliocene } & \multirow{5}{*}{$\begin{array}{c}P . \\
\text { prismatium? }\end{array}$} & $18 \mathrm{X}-\mathrm{CC}$ & $\mathbf{R}$ & $\mathbf{P}$ & . & . & . & . & . & . & . & . \\
\hline & & 19X-CC & - & - & . & . & . & . & . & . & . & . \\
\hline & & $20 \mathrm{X}-\mathrm{CC}$ & F & G & P & + & P & P & + & - & . & . \\
\hline & & $21 \mathrm{X}-\mathrm{CC}$ & F & G & P & + & P & P & $\mathbf{P}$ & - & . & . \\
\hline & & $22 \mathrm{X}-\mathrm{CC}$ & F & G & - & + & P & - & P & - & $i$ & \\
\hline & & $23 \mathrm{X}-\mathrm{CC}$ & F & G & . & - & P & - & . & - & P & ? \\
\hline & & $24 \mathrm{X}-\mathrm{CC}$ & C & G & . & $?$ & P & - & . & . & P & P \\
\hline & S. pentas & $25 \mathrm{X}-\mathrm{CC}$ & $\mathbf{R}$ & G & . & $\mathrm{P}$ & . & . & . & . & $\mathrm{P}$ & + \\
\hline & & $26 \mathrm{X}-\mathrm{CC}$ & $\mathbf{R}$ & G & . & . & + & . & . & . & $\mathbf{P}$ & . \\
\hline & & $27 \mathrm{X}-\mathrm{CC}$ & R & G & . & + & . & . & . & . & . & . \\
\hline
\end{tabular}

Table 5. Raw data for stratigraphically important species in Hole 725C. For explanation of symbols see Appendix A introduction.

\begin{tabular}{|c|c|c|c|c|c|c|c|c|c|c|c|c|}
\hline Age & $\begin{array}{c}\text { Radiolarian } \\
\text { zone }\end{array}$ & Sample & 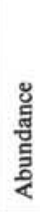 & 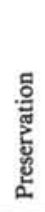 & 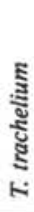 & 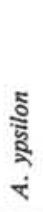 & 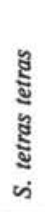 & 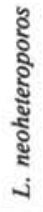 & 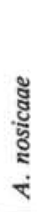 & 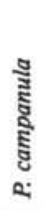 & 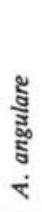 & $\begin{array}{l}\text { yू } \\
\text { हूँ } \\
\dot{v}\end{array}$ \\
\hline \multirow{9}{*}{ Quaternary } & Barren & $10 \mathrm{X}-\mathrm{CC}$ & - & - & . & . & . & . & . & . & . & . \\
\hline & \multirow{7}{*}{ A. angulare } & $11 \mathrm{X}-\mathrm{CC}$ & F & G & . & . & . & . & . & . & . & . \\
\hline & & $12 \mathrm{X}-\mathrm{CC}$ & C & G & . & P & $P$ & . & P & . & $P$ & . \\
\hline & & $13 \mathrm{X}-\mathrm{CC}$ & $\mathbf{F}$ & G & & + & $P$ & . & . & . & . & . \\
\hline & & $14 \mathrm{X}-\mathrm{CC}$ & C & G & P & P & $P$ & - & P & P & $\mathbf{P}$ & . \\
\hline & & $15 \mathrm{X}-\mathrm{CC}$ & $\mathbf{F}$ & G & . & P & . & + & P & . & $\therefore$ & . \\
\hline & & $16 \mathrm{X}-\mathrm{CC}$ & C & G & . & P & $P$ & P & P & + & P & + \\
\hline & & $17 \mathrm{X}-\mathrm{CC}$ & F & G & . & + & . & $\mathbf{P}$ & . & . & . & + \\
\hline & $\overline{\text { Barren }}$ & & & & & & & & & & & \\
\hline
\end{tabular}

Table 6. Raw data for stratigraphically important species in Hole 726A. For explanation of symbols see Appendix $\mathbf{A}$ introduction.

\begin{tabular}{|c|c|c|c|c|c|c|c|c|c|}
\hline Age & $\begin{array}{l}\text { Radiolarian } \\
\text { zone }\end{array}$ & Sample & 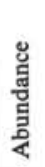 & 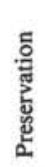 & 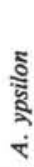 & 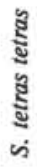 & 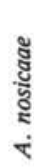 & 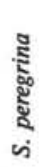 & $\begin{array}{l}\text { y } \\
\text { ฐँ } \\
\dot{\omega}\end{array}$ \\
\hline & Barren & \multirow{7}{*}{$\begin{array}{l}7 \mathrm{X}-\mathrm{CC} \\
8 \mathrm{X}-2,85-87 \\
8 \mathrm{X}-4,85-87 \\
8 \mathrm{H}-\mathrm{CC} \\
9 \mathrm{X}-2,85-87 \\
9 \mathrm{X}-\mathrm{CC}\end{array}$} & \multirow{7}{*}{$\begin{array}{l}- \\
C \\
R \\
C \\
C \\
C\end{array}$} & \multirow{7}{*}{$\begin{array}{l}\bar{G} \\
P \\
\text { G } \\
G \\
G\end{array}$} & . & \multirow[b]{2}{*}{$\mathbf{P}$} & \multirow[b]{2}{*}{+} & \multirow{2}{*}{$\dot{\mathrm{P}}$} & \multirow[t]{2}{*}{. } \\
\hline \multirow{6}{*}{ Pliocene } & & & & & . & & & & \\
\hline & & & & & 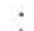 & - & . & $\therefore$ & - \\
\hline & S. pentas & & & & + & $\dot{0}$ & . & $\mathbf{P}$ & . \\
\hline & & & & & $\mathbf{P}$ & $\mathbf{P}$ & $\mathbf{P}$ & $\mathbf{P}$ & 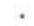 \\
\hline & & & & & . & $\mathbf{P}$ & $\mathrm{P}$ & $\mathbf{P}$ & + \\
\hline & Barren & & & & & & & & \\
\hline
\end{tabular}


Table 7. Raw data for stratigraphically important species in Hole 728A. For explanation of symbols see Appendix $\mathbf{A}$ introduction.

\begin{tabular}{|c|c|c|c|c|c|c|c|c|c|c|c|c|c|c|}
\hline Age & $\begin{array}{l}\text { Radiolarian } \\
\text { zone }\end{array}$ & Sample & 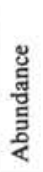 & 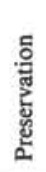 & 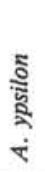 & 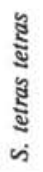 & 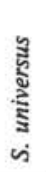 & 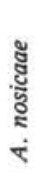 & 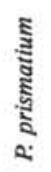 & 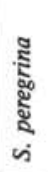 & 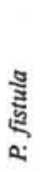 & $\begin{array}{l}\text { ปี } \\
\text { ปี } \\
\text { ป }\end{array}$ & 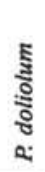 & 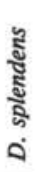 \\
\hline \multirow{6}{*}{ Quaternary } & \multirow{7}{*}{ Barren } & $1 \mathrm{H}-\mathrm{CC}$ & - & - & $\cdot$ & . & . & . & . & . & . & . & . & . \\
\hline & & $2 \mathrm{H}-\mathrm{CC}$ & - & - & . & . & . & . & . & . & . & . & . & . \\
\hline & & 3H-CC & - & - & . & . & . & . & . & . & . & . & . & . \\
\hline & & $4 \mathrm{H}-\mathrm{CC}$ & - & - & . & . & . & . & . & . & . & . & . & . \\
\hline & & SH-CC & + & - & . & . & . & . & - & . & . & . & . & . \\
\hline & & $\begin{array}{l}6 \mathrm{H}-\mathrm{CC} \\
7 \mathrm{H}-\mathrm{CC}\end{array}$ & + & $\bar{z}$ & $\cdot$ & $\cdot$ & · & . & $\cdot$ & . & . & - & . & \\
\hline \multirow{54}{*}{ Pliocene } & & $8 \mathrm{H}-\mathrm{CC}$ & + & $\overline{-}$ & $\vdots$ & $\dot{.}$ & $\dot{.}$ & $\therefore$ & $:$ & + & $\therefore$ & : & ; & : \\
\hline & \multirow{27}{*}{ S. pentas } & 9H-CC & C & G & + & $\dot{\mathrm{P}}$ & $\dot{\mathrm{P}}$ & $\dot{\mathrm{P}}$ & $\dot{-}$ & $P$ & $\therefore$ & + & 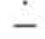 & : \\
\hline & & $10 X-4,85-87$ & $\mathrm{C}$ & G & $\mathbf{P}$ & $\mathrm{P}$ & $\mathrm{P}$ & $\mathrm{P}$ & - & $\mathrm{P}$ & - & $\mathrm{P}$ & - & . \\
\hline & & $10 \mathrm{X}-\mathrm{CC}$ & $\mathrm{F}$ & G & - & + & $\mathbf{P}$ & - & - & $\mathbf{P}$ & - & - & - & . \\
\hline & & $11 X-4,85-87$ & C & $\mathbf{M}$ & + & $\mathbf{P}$ & $\mathbf{P}$ & - & - & $\mathbf{P}$ & - & $\mathbf{P}$ & - & . \\
\hline & & $11 \mathrm{X}-\mathrm{CC}$ & C & G & - & $\mathbf{P}$ & $\mathbf{P}$ & $\mathrm{P}$ & + & $\mathbf{P}$ & + & + & + & . \\
\hline & & $12 X-4,85-87$ & C & G & - & $\mathbf{P}$ & $\mathrm{P}$ & $\mathrm{P}$ & $\mathbf{P}$ & $\mathbf{P}$ & + & $\mathbf{P}$ & $\mathbf{P}$ & . \\
\hline & & $12 \mathrm{X}-\mathrm{CC}$ & C & G & - & $\mathbf{P}$ & $\mathbf{P}$ & $\mathbf{P}$ & - & $\mathbf{P}$ & . & $\mathbf{P}$ & $\mathbf{P}$ & + \\
\hline & & $13 X-4,85-87$ & $\mathrm{C}$ & G & - & - & P & $\mathbf{P}$ & - & $\mathbf{P}$ & + & - & - & $\mathbf{P}$ \\
\hline & & 13X-CC & C & G & - & - & $\mathbf{P}$ & $\mathbf{P}$ & - & $\mathbf{P}$ & . & $\mathbf{P}$ & $\mathbf{P}$ & + \\
\hline & & $14 X-4,85-87$ & $\mathrm{~F}$ & M & . & . & P & $\mathrm{P}$ & . & $\mathbf{P}$ & + & $\mathbf{P}$ & + & . \\
\hline & & $14 \mathrm{X}-\mathrm{CC}$ & $\mathbf{F}$ & G & - & - & $\mathbf{P}$ & $\mathbf{P}$ & . & $\mathbf{P}$ & . & $\mathbf{P}$ & - & - \\
\hline & & $15 X-4,85-87$ & C & G & . & . & P & $\mathrm{P}$ & . & $\mathbf{P}$ & + & - & $\mathbf{P}$ & . \\
\hline & & $15 \mathrm{X}-\mathrm{CC}$ & C & G & . & . & $\mathbf{P}$ & $\mathbf{P}$ & + & $\mathbf{P}$ & $\mathrm{P}$ & $\mathbf{P}$ & $\mathbf{P}$ & . \\
\hline & & $16 X-4,85-87$ & C & M & . & . & $\mathbf{P}$ & $\mathbf{P}$ & $\mathbf{P}$ & $\mathbf{P}$ & $\mathbf{P}$ & $\mathbf{P}$ & $\mathbf{P}$ & . \\
\hline & & $16 \mathrm{X}-\mathrm{CC}$ & C & G & . & . & $\mathbf{P}$ & $\mathbf{P}$ & . & $\mathbf{P}$ & $\mathbf{P}$ & $\mathbf{P}$ & $\mathbf{P}$ & . \\
\hline & & $17 X-4,85-87$ & $\mathrm{C}$ & G & . & . & $\mathbf{P}$ & $\mathbf{P}$ & + & $P$ & . & + & $\mathbf{P}$ & + \\
\hline & & $\begin{array}{l}17 \mathrm{X}-\mathrm{CC} \\
18 \mathrm{X}-\mathrm{CC}\end{array}$ & $\begin{array}{l}C \\
\text { C }\end{array}$ & G & $\cdot$ & $\cdot$ & $\begin{array}{l}P \\
P\end{array}$ & $\begin{array}{l}\mathrm{P} \\
\mathbf{P}\end{array}$ & $\cdot$ & $\begin{array}{l}\mathrm{P} \\
\mathrm{P}\end{array}$ & \pm & $\begin{array}{l}\mathrm{P} \\
\mathrm{P}\end{array}$ & & $\mathrm{P}$ \\
\hline & & $19 X-4,85-87$ & $\mathrm{c}$ & $\mathrm{M}$ & $:$ & : & P & $\mathrm{P}$ & : & P & $\overline{+}$ & $\begin{array}{l}P \\
+\end{array}$ & $\begin{array}{l}\mathbf{P} \\
\mathbf{P}\end{array}$ & $\underline{P}$ \\
\hline & & $19 \mathrm{X}-\mathrm{CC}$ & C & G & . & . & $\mathbf{P}$ & $\mathbf{P}$ & . & $\mathbf{P}$ & - & $\mathbf{P}$ & $\mathbf{P}$ & - \\
\hline & & $20 X-4,85-87$ & C & M & . & . & $\mathbf{P}$ & - & . & $\mathbf{P}$ & - & $\mathbf{P}$ & $\mathbf{P}$ & - \\
\hline & & $20 \mathrm{X}-\mathrm{CC}$ & C & G & . & . & $\mathbf{P}$ & $\mathbf{P}$ & . & $\mathbf{P}$ & - & - & $\mathbf{P}$ & - \\
\hline & & $21 X-4,85-87$ & F & $\mathrm{M}$ & . & . & $\mathbf{P}$ & - & . & $\mathbf{P}$ & - & $\mathbf{P}$ & + & - \\
\hline & & $21 \mathrm{X}-\mathrm{CC}$ & $\mathbf{F}$ & G & . & . & $\mathbf{P}$ & - & . & $\mathbf{P}$ & - & + & + & - \\
\hline & & $22 X-4,85-87$ & C & G & . & . & $\mathbf{P}$ & - & . & $\mathbf{P}$ & + & $\mathbf{P}$ & $\mathbf{P}$ & + \\
\hline & & $22 \mathrm{X}-\mathrm{CC}$ & C & G & . & . & $\mathbf{P}$ & $\mathbf{P}$ & . & $\mathbf{P}$ & - & $\mathbf{P}$ & $\mathbf{P}$ & - \\
\hline & & $23 X-4,85-87$ & C & M & . & . & $\mathbf{P}$ & - & . & $\mathbf{P}$ & $\mathbf{P}$ & $\mathbf{P}$ & + & - \\
\hline & & $23 \mathrm{X}-\mathrm{CC}$ & $\mathrm{F}$ & G & . & . & $\mathbf{P}$ & - & . & $\mathbf{P}$ & $\mathbf{P}$ & $\mathbf{P}$ & $\mathbf{P}$ & - \\
\hline & \multirow{15}{*}{$S$. peregrina } & $24 X-4,85-87$ & C & G & . & . & $\mathbf{P}$ & . & . & $\mathbf{P}$ & $\mathbf{P}$ & $\mathbf{P}$ & $\mathbf{P}$ & $\mathbf{P}$ \\
\hline & & 24X-CC & C & G & . & . & $\mathbf{P}$ & . & . & $\mathbf{P}$ & + & $\mathbf{P}$ & $\mathbf{P}$ & + \\
\hline & & $25 X-4,85-87$ & $\mathbf{R}$ & $\mathbf{P}$ & . & . & $\mathbf{P}$ & . & . & $\mathbf{P}$ & - & - & + & - \\
\hline & & $25 \mathrm{X}-\mathrm{CC}$ & F & G & . & . & $\mathbf{P}$ & + & . & $\mathbf{P}$ & - & - & + & + \\
\hline & & $26 X-4,85-87$ & $\mathbf{F}$ & $\mathbf{M}$ & . & . & $\mathbf{P}$ & . & . & $\mathbf{P}$ & - & $\mathbf{P}$ & - & + \\
\hline & & 26X-CC & C & G & . & . & $\mathbf{P}$ & . & . & $\mathbf{P}$ & $\mathbf{P}$ & $\mathbf{P}$ & $\mathbf{P}$ & $\mathbf{P}$ \\
\hline & & $27 X-4,85-87$ & $\mathrm{~F}$ & M & . & . & $\mathbf{P}$ & . & . & $\mathbf{P}$ & - & $\mathbf{P}$ & + & $\mathbf{P}$ \\
\hline & & $27 \mathrm{X}-\mathrm{CC}$ & C & G & . & . & $\mathbf{P}$ & + & . & $\mathbf{P}$ & $\mathbf{P}$ & $\mathbf{P}$ & $\mathbf{P}$ & $\mathbf{P}$ \\
\hline & & $28 X-4,85-87$ & $\mathbf{R}$ & P & . & . & . & $\mathbf{P}$ & . & $\mathbf{P}$ & - & - & - & - \\
\hline & & $28 \mathrm{X}-\mathrm{CC}$ & $\mathrm{F}$ & G & . & . & $\mathbf{P}$ & . & . & $\mathbf{P}$ & - & $\mathbf{P}$ & - & $\mathbf{P}$ \\
\hline & & $29 X-4,85-87$ & C & G & . & . & $\mathrm{P}$ & $\mathrm{P}$ & . & $\mathbf{P}$ & - & $P$ & - & $\mathbf{P}$ \\
\hline & & $29 \mathrm{X}-\mathrm{CC}$ & C & G & . & . & $\mathbf{P}$ & . & . & $\mathbf{P}$ & $\mathbf{P}$ & - & - & $\mathbf{P}$ \\
\hline & & $30 X-4,85-87$ & C & G & . & . & $\mathbf{P}$ & 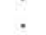 & . & P & + & $\mathbf{P}$ & $\mathbf{P}$ & $\mathbf{P}$ \\
\hline & & $30 \mathrm{X}-\mathrm{CC}$ & C & G & . & . & $\mathbf{P}$ & $\mathbf{P}$ & . & $\mathbf{P}$ & $\mathbf{P}$ & $\mathbf{P}$ & P & $\mathbf{P}$ \\
\hline & & $31 X-4,85-87$ & C & G & . & . & $\mathbf{P}$ & . & . & $\mathrm{P}$ & - & + & + & $\mathbf{P}$ \\
\hline & D. penultima & $31 \mathrm{X}-\mathrm{CC}$ & $\mathrm{F}$ & G & . & . & $\mathbf{P}$ & . & . & $\mathbf{P}$ & $\mathbf{P}$ & $\mathbf{P}$ & - & $\mathbf{P}$ \\
\hline & & $32 \times-4,85-87$ & C & G & . & . & $\mathbf{P}$ & 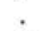 & . & $\mathbf{P}$ & - & - & + & $\mathbf{P}$ \\
\hline & \multirow{9}{*}{ D. antepenultima } & $32 \mathrm{X}-\mathrm{CC}$ & C & G & . & . & $\mathbf{P}$ & $\mathbf{P}$ & . & $\mathbf{P}$ & $\mathbf{P}$ & - & $\mathbf{P}$ & $\mathbf{P}$ \\
\hline & & $33 X-4,85-87$ & C & G & . & . & P & . & . & + & $\mathbf{P}$ & $\mathbf{P}$ & P & $\mathbf{P}$ \\
\hline & & $33 \mathrm{X}-\mathrm{CC}$ & C & G & . & . & $\mathbf{P}$ & . & . & - & $P$ & $P$ & P & $\mathbf{P}$ \\
\hline & & $34 X-4,85-87$ & C & G & . & . & $\mathbf{P}$ & 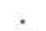 & . & - & $\mathbf{P}$ & $\mathbf{P}$ & $\mathbf{P}$ & $\mathbf{P}$ \\
\hline & & $34 \mathrm{X}-\mathrm{CC}$ & C & G & . & . & $\mathbf{P}$ & $\mathbf{P}$ & . & . & - & $\mathbf{P}$ & $\mathbf{P}$ & $\mathbf{P}$ \\
\hline & & $35 X-4,85-87$ & C & G & . & . & $\mathbf{P}$ & . & . & . & - & $\mathbf{P}$ & $\mathbf{P}$ & $\mathbf{P}$ \\
\hline & & $35 \mathrm{X}-\mathrm{CC}$ & C & G & . & . & $\mathrm{P}$ & . & . & . & $\mathbf{P}$ & $\mathbf{P}$ & $\mathbf{P}$ & $\mathbf{P}$ \\
\hline & & $36 X-4,85-87$ & C & G & . & . & $\mathbf{P}$ & . & . & . & - & + & + & $\mathbf{P}$ \\
\hline & & $36 \mathrm{X}-\mathrm{CC}$ & C & G & . & . & P & . & . & . & $\mathrm{P}$ & - & $\mathbf{P}$ & $\mathbf{P}$ \\
\hline
\end{tabular}


Table 7 (continued).

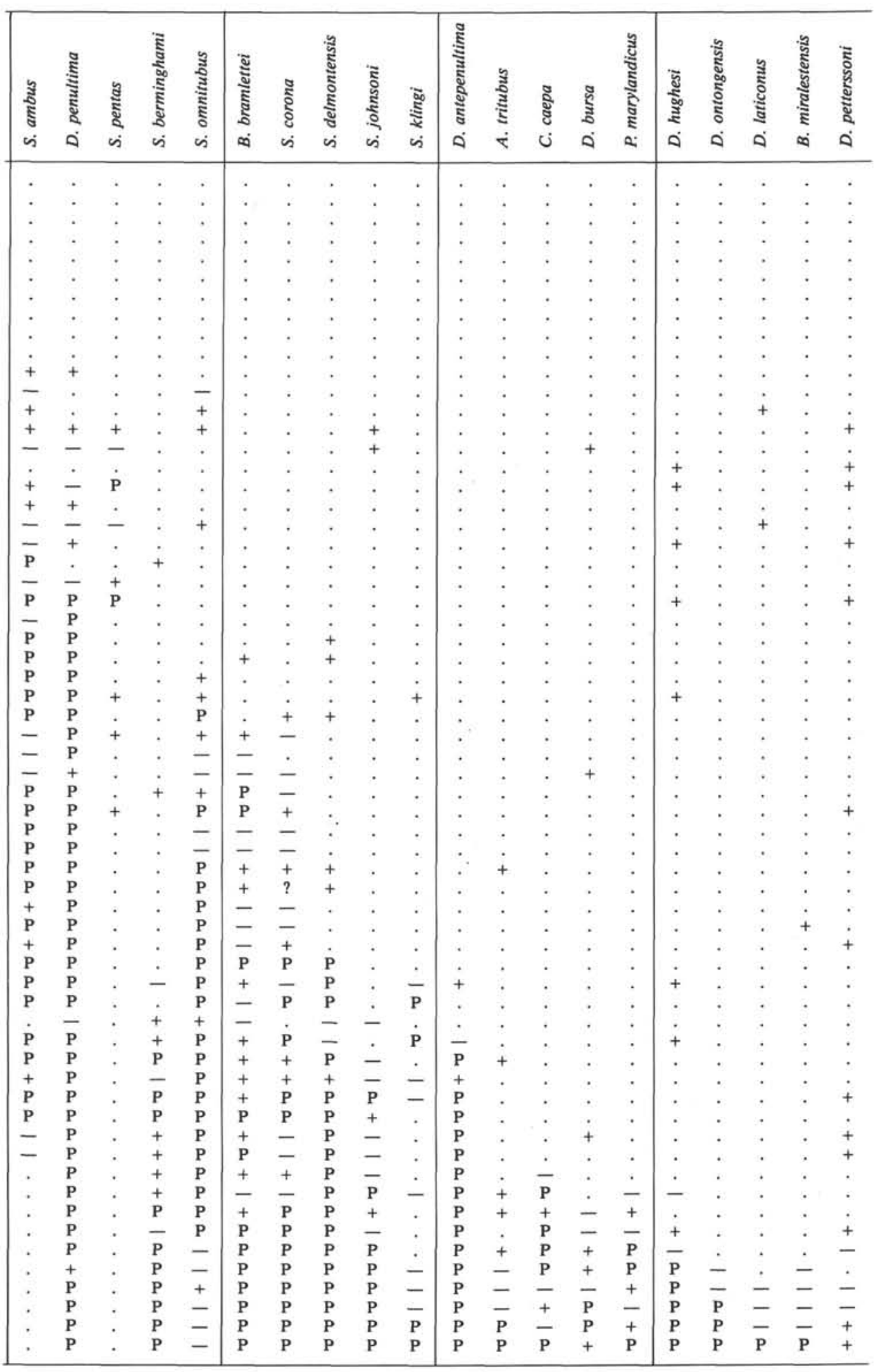


Table 8. Raw data for stratigraphically important species in Hole 730A. For explanation of symbols see Appendix A introduction.

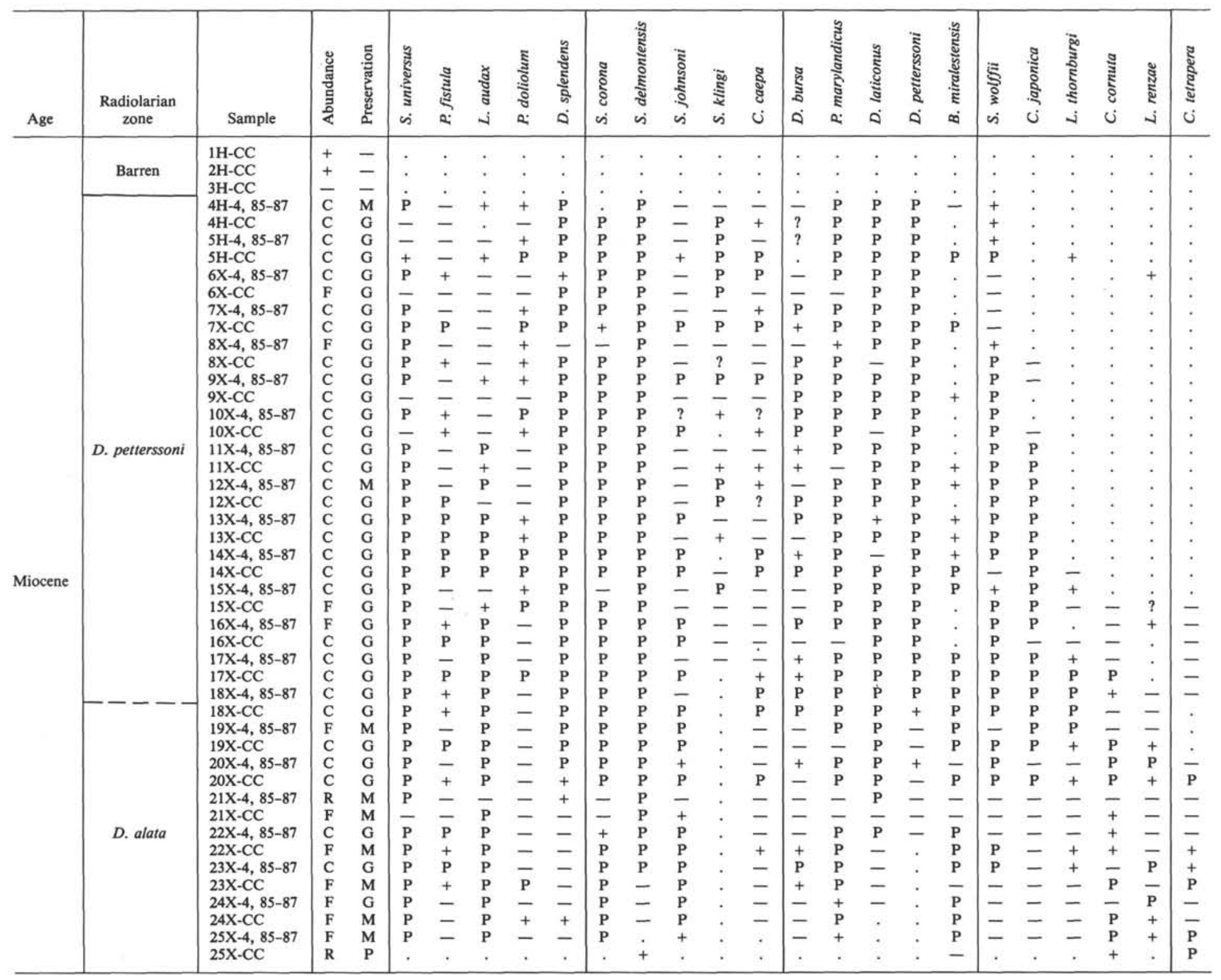


Table 9. Raw data for stratigraphically important species in Hole 731A. For explanation of symbols see Appendix A introduction.

\begin{tabular}{|c|c|c|c|c|c|c|c|c|c|c|c|c|c|c|c|c|c|c|c|c|c|c|c|c|c|}
\hline Age & $\begin{array}{l}\text { Radiolarian } \\
\text { zone }\end{array}$ & Sample & 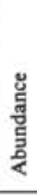 & 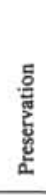 & 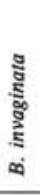 & 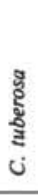 & 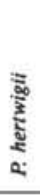 & $\begin{array}{l}\text { ฐू है } \\
\text { है } \\
\text { है }\end{array}$ & 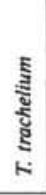 & $\begin{array}{l}\text { हूँ } \\
\text { है } \\
\text { है } \\
\text { ن }\end{array}$ & 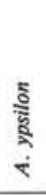 & $\begin{array}{l}\text { हू } \\
\text { sू } \\
\text { sू } \\
\text { us }\end{array}$ & $\begin{array}{l}\text { है } \\
\text { है } \\
\text { है } \\
\text { vं }\end{array}$ & 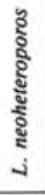 & $\begin{array}{l}\text { हूँ } \\
\text { हू } \\
\text { ह } \\
\text { र }\end{array}$ & $\begin{array}{l}\text { डँच } \\
\text { हूँ } \\
\text { हू } \\
\text { \&. }\end{array}$ & 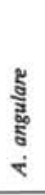 & 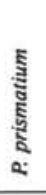 & $\begin{array}{l}\text { हूँ } \\
\text { हूँ } \\
\text { हू } \\
\text { v' }\end{array}$ & 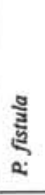 & 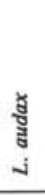 & 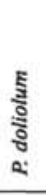 & $\begin{array}{l}\text { हूँ } \\
\text { हूँ } \\
\text { जू } \\
\text { वे }\end{array}$ & $\begin{array}{l}\text { ज्ञ } \\
\text { है } \\
\text { uे }\end{array}$ & $\begin{array}{l}\text { है } \\
\text { है } \\
\text { है } \\
\vdots \\
0\end{array}$ \\
\hline \multirow{12}{*}{ Quaternary } & \multirow{8}{*}{ A. ypsilon } & $1 \mathrm{H}-4,85-87$ & F & M & - & - & - & - & - & - & $\mathbf{P}$ & + & - & . & . & . & . & . & . & + & . & . & . & . & . \\
\hline & & $1 \mathrm{H}-\mathrm{CC}$ & F & M & - & - & - & + & - & - & $\mathbf{P}$ & $\mathbf{P}$ & - & . & . & . & . & . & . & . & . & . & . & . & . \\
\hline & & $2 \mathrm{H}-\mathrm{CC}$ & F & $\mathbf{P}$ & - & - & - & - & - & - & - & P & + & , & - & , & . & . & . & . & . & . & . & . & . \\
\hline & & $\begin{array}{l}3 \mathrm{H}-4,85-87 \\
3 \mathrm{H}-\mathrm{CC}\end{array}$ & C & G & . & . & $\stackrel{P}{P}$ & $\overline{7}$ & - & $\begin{array}{l}\mathrm{P} \\
\mathrm{P}\end{array}$ & $\mathbf{P}$ & P & P & . & - & - & . & . & $\cdot$ & . & . & . & $\cdot$ & . & . \\
\hline & & $\begin{array}{l}3 \mathrm{H}-\mathrm{CC}, 85-87 \\
\end{array}$ & c & G & : & $:$ & P & P & $\begin{array}{lll}+ \\
+\end{array}$ & ${ }_{\mathrm{P}}^{\mathrm{P}}$ & $\overline{\mathrm{P}}$ & & ${ }_{\mathrm{P}}^{+}$ & $\dot{5}$ & + & $\dot{\mathrm{p}}$ & $\bar{z}$ & . & $\cdot$ & i & . & · & . & - & . \\
\hline & & $4 \mathrm{H}-\mathrm{CC}$ & c & G & . & . & - & $\mathrm{P}$ & + & $\mathrm{P}$ & $\mathrm{P}$ & $\mathrm{P}$ & - & $:$ & $\mathrm{P}$ & $\mathrm{P}$ & - & $\therefore$ & $:$ & + & $:$ & $\therefore$ & $:$ & $\therefore$ & : \\
\hline & & $5 \mathrm{H}-4,85-87$ & c & G & . & . & . & P & P & P & - & $P$ & $P$ & - & P & $\mathrm{P}$ & + & . & . & . & . & . & + & . & : \\
\hline & & SH-CC & c & G & . & . & . & P & P & $P$ & P & $P$ & $\mathbf{P}$ & + & $P$ & $P$ & - & . & . & . & . & . & . & . & . \\
\hline & \multirow{4}{*}{ A. angulare } & $6 \mathrm{H}-4,85-87$ & C & M & . & . & . & $?$ & + & P & $\mathbf{P}$ & P & $\mathrm{P}$ & $\mathrm{P}$ & $\mathbf{P}$ & - & $\mathrm{P}$ & $\cdot$ & + & . & . & . & $\cdot$ & . & . \\
\hline & & $\begin{array}{l}6 \mathrm{H}-\mathrm{CC} \\
7 \mathrm{H}-4,85-87\end{array}$ & C & $\mathrm{M}$ & · & : & $\cdot$ & - & $\overline{-}$ & $\begin{array}{l}\mathrm{P} \\
\mathrm{P}\end{array}$ & $\stackrel{+}{\mathrm{P}}$ & $\stackrel{P}{P}$ & $\stackrel{P}{P}$ & $\mathrm{P}$ & $\overline{\mathrm{p}}$ & $\stackrel{+}{p}$ & $\begin{array}{l}\mathrm{P} \\
\mathrm{P}\end{array}$ & - & $\cdot$ & . & . & . & . & . & - \\
\hline & & $7 \mathrm{H}-\mathrm{CC}$ & c & $\mathrm{G}$ & : & $\dot{i}$ & $\cdot$ & : & $\overline{+}$ & $\mathrm{P}$ & $\mathrm{P}$ & $\mathrm{P}$ & $\mathrm{P}$ & $\mathrm{P}$ & P & $P_{P}^{P}$ & ${ }_{P}^{P}$ & - & . & . & . & + & . & . & . \\
\hline & & $8 X-4,85-87$ & C & G & : & $:$ & $:$ & : & - & $\mathrm{P}$ & + & $\mathrm{P}$ & P & $\mathrm{P}$ & + & - & $\frac{\mathrm{P}}{-}$ & $=$ & : & : & $\dot{5}$ & : & i & : & i \\
\hline \multirow{8}{*}{ Pliocene } & \multirow{5}{*}{ P. prismatium } & $8 \mathrm{X}-\mathrm{CC}$ & c & G & . & . & . & . & . & P & + & $P$ & P & P & P & . & . & + & . & . & . & . & . & . & . \\
\hline & & $9 X-4,85-87$ & c & M & . & . & . & . & . & P & - & - & $\mathrm{P}$ & P & - & - & . & . & + & - & . & . & . & . & . \\
\hline & & $9 \mathrm{X}-\mathrm{CC}$ & c & G & . & . & . & . & . & P & $\mathbf{P}$ & P & $\mathbf{P}$ & $P$ & $\mathbf{P}$ & . & . & + & + & $\mathbf{P}$ & . & . & . & . & . \\
\hline & & $10 X-4,85-87$ & C & M & . & . & . & . & . & - & $\mathbf{P}$ & $P$ & $\mathbf{P}$ & + & $\mathbf{P}$ & . & . & + & - & $\mathbf{P}$ & . & - & - & . & - \\
\hline & & $10 x-C C$ & c & G & . & . & . & . & . & $P$ & $\mathbf{P}$ & $P$ & $\mathbf{P}$ & + & $P$ & . & . & + & - & $P$ & - & - & . & - & - \\
\hline & \multirow{3}{*}{ S. pentas } & $11 X-4,85-87$ & c & G & . & . & . & . & . & - & - & - & $P$ & - & $P$ & . & . & . & $\mathbf{P}$ & $\mathbf{P}$ & $\mathrm{P}$ & $\mathbf{P}$ & . & $\bar{x}$ & + \\
\hline & & $11 X-C C$ & c & G & . & . & . & . & . & - & - & + & P & . & P & + & . & + & P & + & $P$ & $P$ & - & $\mathbf{P}$ & + \\
\hline & & $12 X-4,85-87$ & c & G & . & . & . & . & . & . & . & - & $\mathbf{P}$ & . & + & . & . & + & P & + & $P$ & + & - & $\mathbf{P}$ & $\mathbf{P}$ \\
\hline \multirow{33}{*}{ Miocene } & \multirow{6}{*}{ D. penultima } & $12 \mathrm{X}-\mathrm{CC}$ & C & G & . & . & . & 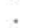 & 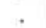 & . & . & . & $P$ & . & - & . & . & - & P & + & $P$ & + & $\mathbf{P}$ & $\mathbf{P}$ & $\mathbf{P}$ \\
\hline & & $13 \times-4,85-87$ & C & G & . & . & . & . & . & . & . & : & $\mathbf{P}$ & . & $\mathbf{P}$ & . & . & . & $P$ & $\mathbf{P}$ & $\mathbf{P}$ & $\mathbf{P}$ & $\mathbf{P}$ & - & $\mathbf{P}$ \\
\hline & & $13 \mathrm{X}-\mathrm{CC}$ & C & G & . & . & . & . & . & . & . & . & $P$ & . & - & . & . & . & + & $P$ & $\mathbf{P}$ & P & $\mathbf{P}$ & . & P \\
\hline & & $14 X-4,85-87$ & C & G & . & . & . & . & . & . & . & . & P & : & $\mathbf{P}$ & . & . & . & . & $P$ & P & $\mathbf{P}$ & $\mathbf{P}$ & . & $\mathbf{P}$ \\
\hline & & $14 X-C C$ & C & G & . & . & . & . & . & . & . & . & $P$ & . & - & . & . & . & . & + & $P$ & $\mathbf{P}$ & $P$ & . & $\mathbf{P}$ \\
\hline & & $15 X-4,85-87$ & C & G & . & . & . & . & . & . & . & . & $\mathrm{P}$ & . & P & . & . & . & + & $\mathbf{P}$ & $\cdot \mathbf{P}$ & $P$ & $\mathbf{P}$ & . & $\mathbf{P}$ \\
\hline & \multirow{8}{*}{ D. antepenultima } & $15 \mathrm{X}-\mathrm{CC}$ & C & G & . & . & . & . & . & . & . & . & $\mathbf{P}$ & . & - & . & . & . & . & $\mathbf{P}$ & $\mathbf{P}$ & $P$ & $\mathbf{P}$ & . & $\mathbf{P}$ \\
\hline & & $16 X-4,85-87$ & C & G & . & . & . & . & . & . & . & . & $\mathbf{P}$ & . & . & . & . & . & + & $\overline{0}$ & $P$ & $\mathrm{P}$ & $\mathrm{P}$ & . & $\mathbf{P}$ \\
\hline & & 16X-CC & c & G & . & . & . & . & . & . & . & . & $P$ & . & . & . & . & . & + & P & P & $\mathrm{P}$ & $\mathbf{P}$ & . & $\mathbf{P}$ \\
\hline & & $17 X-4,85-87$ & C & G & . & . & . & . & . & . & . & . & $P$ & . & . & . & . & . & + & $\mathbf{P}$ & $\mathbf{P}$ & $P$ & $\mathbf{P}$ & . & P \\
\hline & & $17 \mathrm{X}-\mathrm{CC}$ & C & G & . & . & . & . & . & . & . & . & P & . & . & . & . & . & . & $P$ & $P$ & $\mathbf{P}$ & $\mathbf{P}$ & . & p \\
\hline & & $18 X-4,85-87$ & $\mathrm{~F}$ & G & . & . & . & . & . & . & . & . & P & . & . & . & . & + & . & - & $\mathbf{P}$ & $\mathbf{P}$ & $\mathbf{P}$ & . & + \\
\hline & & 18X-CC & C & $\mathrm{G}$ & . & . & . & . & . & . & . & . & $P$ & . & . & . & . & . & . & - & - & - & $\mathbf{P}$ & . & , \\
\hline & & $19 \times-4,85-87$ & c & G & . & . & . & . & . & . & . & . & P & . & . & . & . & . & . & + & $P$ & $P$ & $P$ & . & . \\
\hline & & 19X-CC & C & G & . & . & . & 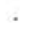 & 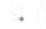 & . & . & 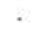 & $P$ & 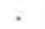 & . & . & . & . & . & $\mathbf{P}$ & $P$ & $\mathbf{P}$ & $P$ & . & . \\
\hline & & $20 X-4,85-87$ & C & G & . & . & . & . & . & . & . & . & P & . & . & . & . & . & . & + & $P$ & $P$ & $\mathbf{P}$ & . & . \\
\hline & & $20 \mathrm{X}-\mathrm{CC}$ & c & G & . & . & . & . & . & . & . & . & $\mathbf{P}$ & . & . & . & . & . & . & $P$ & + & $P$ & $P$ & . & . \\
\hline & & $21 X-4,85-87$ & C & G & . & . & . & . & . & . & . & . & $\mathrm{P}$ & . & . & . & . & . & . & $P$ & $P$ & $P$ & $P$ & . & . \\
\hline & & $21 \mathrm{X}-\mathrm{CC}$ & $\mathbf{F}$ & M & . & . & . & . & . & . & . & . & $P$ & . & . & . & . & . & . & . & - & + & + & . & . \\
\hline & & $22 X-4,85-87$ & C & G & . & . & . & . & . & . & : & . & $\mathrm{P}$ & . & . & . & . & . & . & + & $P$ & $\mathbf{P}$ & $\mathbf{P}$ & . & . \\
\hline & & $22 \mathrm{X}-\mathrm{CC}$ & $\mathrm{F}$ & $\mathrm{M}$ & . & & . & . & . & . & . & . & $P$ & . & . & . & . & . & . & - & $\bar{x}$ & - & $\overline{0}$ & . & . \\
\hline & & $23 X-4,85-87$ & c & M & . & . & . & . & . & & . & . & $\mathbf{P}$ & . & . & . & . & . & . & + & $P$ & - & $P$ & . & . \\
\hline & & $23 \mathrm{X}-\mathrm{CC}$ & $\mathrm{F}$ & M & . & . & . & . & . & 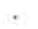 & . & . & $\mathbf{P}$ & . & . & . & . & . & . & - & $\mathrm{P}$ & + & $\mathbf{P}$ & . & . \\
\hline & D. petterssoni & $24 X-4,85-87$ & $\mathrm{~F}$ & M & . & . & . & . & . & . & . & 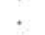 & P & . & & . & . & . & . & + & $\mathbf{P}$ & - & + & . & . \\
\hline & & 24X-CC & C & G & . & . & . & . & . & . & . & . & $P$ & . & . & . & . & . & . & . & + & $\bar{n}$ & $P$ & . & . \\
\hline & & $25 X-4,85-87$ & C & G & . & . & . & . & . & . & . & . & $P$ & . & . & . & . & . & . & . & + & $P$ & $P$ & . & . \\
\hline & & $25 \mathrm{X}-\mathrm{CC}$ & C & G & . & . & . & . & . & . & . & . & P & . & . & . & . & . & . & + & $\mathbf{P}$ & . & $P$ & . & . \\
\hline & & $26 \times-4,85-87$ & $\mathrm{~F}$ & M & . & . & . & . & . & . & . & . & $\mathbf{P}$ & . & . & . & . & . & . & $P$ & - & - & $\mathbf{P}$ & . & . \\
\hline & & 26X-CC & c & $\mathrm{M}$ & . & . & . & . & . & . & . & . & $P$ & . & . & . & . & . & . & + & + & - & $P$ & . & . \\
\hline & & $27 \times-4,85-87$ & C & G & 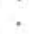 & 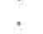 & 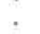 & . & . & . & 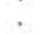 & 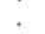 & $\mathbf{p}$ & 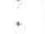 & $\sigma_{0}$ & . & . & . & . & $\mathbf{P}$ & $\mathbf{P}$ & . & $\mathbf{P}$ & . & . \\
\hline & & $27 \mathrm{X}-\mathrm{CC}$ & C & G & . & . & . & . & . & . & v & v & P & . & $\cdot$ & . & . & . & . & $\mathbf{P}$ & + & $\mathbf{P}$ & $P$ &. & th \\
\hline & & $28 \times-4,85-87$ & $\mathbf{F}$ & M & . & . & . & . & . & . & . & . & $\mathrm{P}$ & . & . & . & . & . & . & $\mathbf{P}$ & $P$ & - & $\mathbf{P}$ & . & . \\
\hline & & 28X-CC & $\mathbf{R}$. & P & . & . & . & 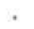 & . & . & . & . & $P$ & . & . & . & . & . & . & - & $\mathrm{P}$ & - & + & $\cdot$ & \\
\hline
\end{tabular}


Table 9 (continued).

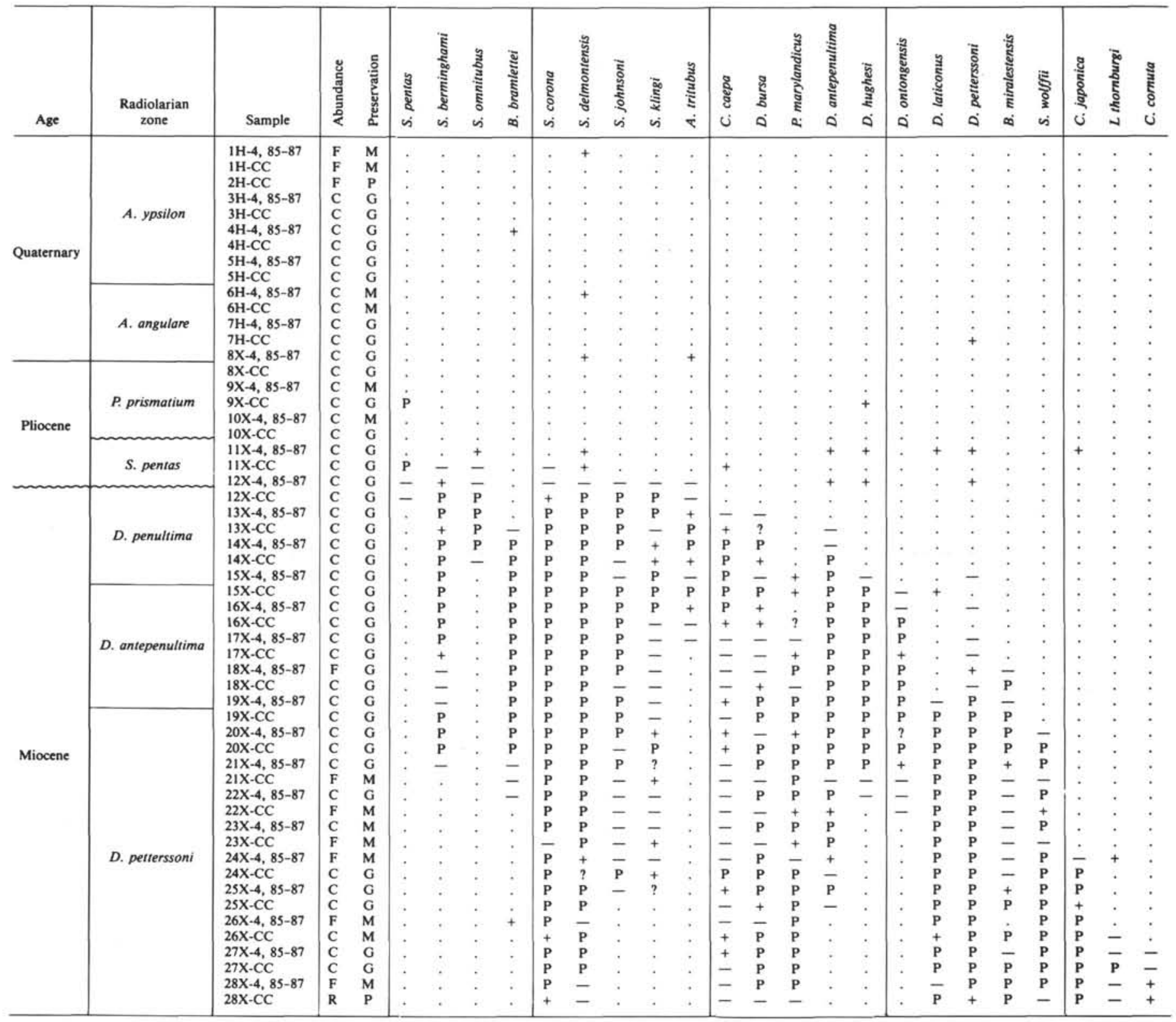


Table 10. Raw data for species associated with upwelling in Holes $721 \mathrm{~A}$ and $721 \mathrm{~B} . \mathrm{C}=$ common; $\mathbf{F}=$ few; $R=R a r e ;+=$ one or two specimens; $-=$ searched for and found to be absent; ? = dubious identification.

\begin{tabular}{|c|c|c|c|c|c|c|c|c|c|c|c|c|c|c|c|c|c|c|c|c|}
\hline Age & $\begin{array}{l}\text { Radiolarian } \\
\text { zone }\end{array}$ & Sample & 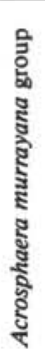 & 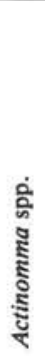 & 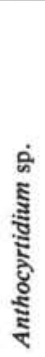 & 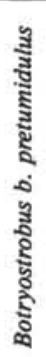 & 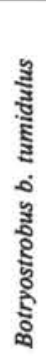 & 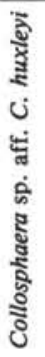 & 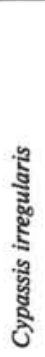 & 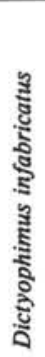 & 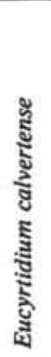 & 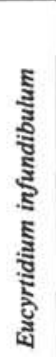 & 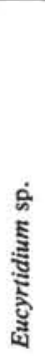 & 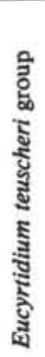 & 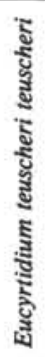 & 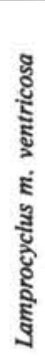 & 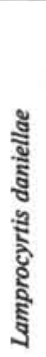 & 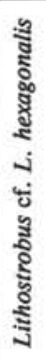 & 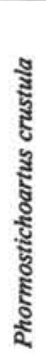 & 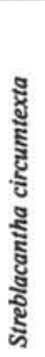 \\
\hline \multirow{8}{*}{ Quaternary } & C. tuberosa & A-1H-4, 85-87 & $\mathbf{R}$ & - & - & - & $\mathbf{R}$ & $\overline{0}$ & - & - & - & $\bar{\Sigma}$ & - & . & $\overline{8}$ & $\mathbf{R}$ & . & - & - & R \\
\hline & \multirow{4}{*}{ A. ypsilon? } & $\begin{array}{l}\text { A-1H-CC } \\
\text { A-2H-4, 85-87 }\end{array}$ & $\underline{C}$ & $\stackrel{+}{-}$ & 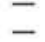 & $\overline{-}$ & C & $\underline{\mathbf{R}}$ & $\bar{z}$ & $\overline{-}$ & $\bar{z}$ & $\frac{F}{-}$ & $\overline{-}$ & $\therefore$ & $\stackrel{R}{-}$ & $\dot{-}$ & : & $\bar{z}$ & $\bar{z}$ & $\begin{array}{l}\mathbf{R} \\
+\end{array}$ \\
\hline & & A- $2 \mathrm{H}-\mathrm{CC}$ & - & - & - & - & - & F & - & - & + & - & - & - & - & - & . & - & - & - \\
\hline & & A-3H-CC & + & - & . & . & . & C & - & - & - & - & . & - & - & - & . & . & . & + \\
\hline & & A-4H-4, 85-87 & - & $\mathbf{F}$ & . & . & . & C & - & - & + & - & . & - & - & - & . & . & . & $\mathbf{R}$ \\
\hline & \multirow{3}{*}{ A. angulare } & A-4H-CC & + & $\mathbf{R}$ & - & - & $\mathbf{R}$ & $\mathrm{C}$ & - & $\mathbf{R}$ & $\mathrm{F}$ & + & . & . & F & . & . & . & - & $\mathbf{R}$ \\
\hline & & A-5H-4, 85-87 & C & C & - & - & + & + & - & - & + & - & . & - & + & $\mathbf{R}$ & . & + & - & $\mathbf{R}$ \\
\hline & & A-5H-CC & C & C & . & . & $\mathbf{R}$ & + & - & - & - & + & . & - & + & - & . & - & - & + \\
\hline \multirow{20}{*}{ Pliocene } & \multirow{6}{*}{ P. prismatium } & A-6H-4, 85-87 & C & $\mathbf{R}$ & . & . & + & + & - & - & - & - & . & - & + & - & . & . & + & + \\
\hline & & A-6H-CC & $\mathbf{F}$ & + & . & : & $\therefore$ & - & - & - & - & - & - & - & $\begin{array}{l}\mathbf{R} \\
\mathbf{R}\end{array}$ & - & . & - & . & - \\
\hline & & A-7H-4, 85-87 & C & $\mathbf{R}$ & - & + & $\begin{array}{l}R \\
R\end{array}$ & - & - & - & $\bar{F}$ & - & + & - & $\mathbf{R}$ & - & . & + & - & $\bar{z}$ \\
\hline & & $\begin{array}{l}\text { A-7H-CC } \\
\text { A-8H-4, 85-87 }\end{array}$ & $\begin{array}{l}\mathrm{C} \\
\mathrm{C}\end{array}$ & $\begin{array}{l}\mathbf{F} \\
+\end{array}$ & $\dot{.}$ & $\therefore$ & $\hat{F}$ & $\therefore$ & $\dot{-}$ & $\dot{-}$ & $\begin{array}{l}F \\
+\end{array}$ & + & $\begin{array}{l}\mathbf{R} \\
\mathbf{R}\end{array}$ & $\therefore$ & $\begin{array}{l}R \\
+\end{array}$ & $\therefore$ & : & $\stackrel{+}{-}$ & $\overline{\text {. }}$ & $\overline{+}$ \\
\hline & & $\mathrm{A}-8 \mathrm{H}-\mathrm{CC}$ & C & C & . & $\mathbf{R}$ & C & . & . & . & $\mathbf{R}$ & . & . & . & . & . & . & . & . & $\mathbf{R}$ \\
\hline & & A-9H-4, 85-87 & C & C & . & C & $\mathbf{R}$ & - & - & . & $\mathbf{R}$ & - & . & - & + & - & . & - & . & $\mathbf{R}$ \\
\hline & \multirow{14}{*}{ S. pentas } & A-9H-CC & C & C & - & $\mathbf{F}$ & $\mathbf{R}$ & - & . & . & + & - & - & - & - & - & - & - & . & . \\
\hline & & B-10X-4, 85-87 & C & $\mathbf{F}$ & - & - & - & - & . & . & - & - & - & - & - & . & . & - & - & - \\
\hline & & B-10X-CC & C & C & $\mathbf{F}$ & - & + & - & . & . & - & - & + & - & $\mathbf{R}$ & - & . & - & - & + \\
\hline & & B-11X-4, 85-87 & C & $\mathbf{F}$ & $\mathbf{R}$ & - & - & - & . & . & + & - & - & - & + & + & . & + & . & $\mathbf{R}$ \\
\hline & & B-11X-CC & C & F & $\mathbf{R}$ & - & - & . & . & . & - & + & . & . & $\mathbf{R}$ & . & . & . & . & - \\
\hline & & B-12X-CC & C & F & - & - & - & . & . & . & - & + & . & + & - & - & . & - & . & $\mathbf{R}$ \\
\hline & & B-13X-4, 85-87 & $\mathbf{F}$ & $\mathbf{F}$ & - & $\mathbf{R}$ & - & + & . & . & $\mathbf{F}$ & - & - & $\mathbf{R}$ & - & - & . & - & - & - \\
\hline & & B-13X-CC & C & C & + & $\mathbf{R}$ & . & - & . & . & F & + & + & $\mathbf{F}$ & + & - & . & + & F & - \\
\hline & & B-14X-4, 85-87 & $\mathrm{C}$ & $\mathbf{R}$ & - & $\mathbf{R}$ & - & . & . & . & $\mathbf{R}$ & - & - & - & - & . & . & - & $\mathbf{R}$ & - \\
\hline & & B-14X-CC & C & $\mathbf{R}$ & - & $\mathbf{R}$ & . & - & . & . & $\mathbf{R}$ & $\mathbf{R}$ & $\mathbf{R}$ & $\mathbf{R}$ & . & . & . & $\mathbf{R}$ & F & . \\
\hline & & B-15X-4, 85-87 & C & F & $\mathbf{R}$ & F & . & . & . & . & $\mathbf{R}$ & - & - & $\mathbf{R}$ & . & . & - & - & $\mathbf{R}$ & + \\
\hline & & B-15X-CC & C & C & - & $\mathbf{F}$ & . & . & . & . & $\mathbf{R}$ & $\mathbf{R}$ & . & $\mathbf{F}$ & . & . & + & + & + & . \\
\hline & & B-16X-4, 85-87 & $\mathbf{R}$ & $\mathbf{R}$ & - & - & $\mathbf{F}$ & . & . & . & $\mathbf{R}$ & - & + & - & - & - & + & - & $\mathbf{R}$ & - \\
\hline & & B-16X-CC & F & $\mathbf{F}$ & - & $\mathbf{F}$ & $\mathbf{F}$ & - & . & . & $\mathbf{F}$ & $\mathbf{R}$ & $\mathbf{R}$ & $\mathbf{R}$ & . & . & $\mathbf{R}$ & . & $\mathrm{F}$ & - \\
\hline \multirow{29}{*}{ Miocene } & \multirow{15}{*}{ S. peregrina } & B-17X-4, 85-87 & + & - & $?$ & $\mathbf{R}$ & . & - & . & . & $\mathbf{F}$ & + & . & $\mathbf{R}$ & . & . & + & $\therefore$ & $\mathbf{R}$ & . \\
\hline & & B-17X-CC & $\mathbf{R}$ & $\mathbf{R}$ & $\mathbf{R}$ & . & . & F & . & . & $\mathbf{R}$ & $\mathbf{R}$ & . & $\mathbf{R}$ & . & . & - & $\mathbf{R}$ & C & - \\
\hline & & B-18X-4, 85-87 & - & - & . & - & . & - & . & . & + & + & - & - & - & . & . & - & $\mathbf{R}$ & - \\
\hline & & B-18X-CC & $\mathbf{R}$ & $\mathbf{R}$ & . & . & . & - & . & . & $\mathbf{F}$ & - & - & $\mathbf{R}$ & - & . & . & + & F & - \\
\hline & & B-19X-4, 85-87 & + & $\mathbf{R}$ & + & + & $?$ & $\mathbf{R}$ & . & . & $\mathbf{R}$ & - & - & - & . & . & - & - & + & - \\
\hline & & B-19X-CC & $\mathbf{R}$ & - & - & . & . & - & . & . & $\mathbf{R}$ & - & . & + & . & . & . & - & - & - \\
\hline & & B- $20 X-4,85-87$ & $\mathbf{R}$ & + & - & . & . & F & . & . & - & - & - & $\mathbf{R}$ & - & . & . & - & + & - \\
\hline & & B-20X-CC & + & $\mathbf{R}$ & . & . & . & $\mathbf{R}$ & . & . & $\mathbf{R}$ & . & . & . & . & . & . & . & - & . \\
\hline & & B-21X-CC & + & $\mathbf{R}$ & . & . & . & $\mathbf{R}$ & . & . & $\mathbf{F}$ & - & . & + & - & . & . & - & + & - \\
\hline & & B-22X-4, 85-87 & - & - & - & - & . & . & . & . & - & $\mathbf{R}$ & . & - & . & . & . & $\mathbf{R}$ & + & - \\
\hline & & B-22X-CC & - & $\mathbf{R}$ & - & . & . & $\mathbf{R}$ & . & . & $\mathbf{R}$ & + & . & $\mathbf{R}$ & . & . & . & 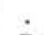 & . & . \\
\hline & & B- $23 X-3,85-87$ & - & - & - & . & . & - & . & . & $\mathbf{R}$ & . & . & $\mathbf{R}$ & . & . & . & $\mathbf{R}$ & $\mathbf{R}$ & . \\
\hline & & B-23X-CC & $\mathbf{R}$ & + & . & . & . & F & . & . & $\mathbf{R}$ & - & - & $\mathbf{R}$ & - & . & . & $\mathbf{R}$ & $\mathbf{R}$ & - \\
\hline & & B- $24 X-3,85-87$ & - & + & . & . & . & - & . & . & $\mathbf{R}$ & + & . & - & . & . & . & - & - & - \\
\hline & & B-24X-CC & + & $\mathbf{R}$ & . & . & . & $\mathbf{R}$ & . & . & F & . & . & $\mathbf{R}$ & . & . & . & . & $\mathbf{R}$ & . \\
\hline & \multirow{5}{*}{ D. penultima } & B- $25 X-4,85-87$ & . & $\mathbf{R}$ & . & . & . & 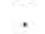 & . & . & ${ }^{\circ}$ & . & . & $\mathbf{R}$ & . & . & . & . & . & . \\
\hline & & B-25X-CC & + & - & - & . & . & F & . & . & $?$ & - & . & $\mathbf{R}$ & - & . & . & - & - & - \\
\hline & & B- $26 X-4,85-87$ & . & $\mathbf{R}$ & . & . & . & 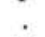 & . & . & + & . & . & . & . & . & . & . & . & . \\
\hline & & B-26X-CC & $\mathbf{R}$ & - & . & . & . & F & . & . & - & $\mathbf{R}$ & . & $\mathbf{R}$ & . & . & . & + & + & - \\
\hline & & B- $27 X-4,85-87$ & - & - & . & . & . & F & . & . & - & - & . & - & - & . & . & $\mathbf{R}$ & - & - \\
\hline & & B-27X-CC & $\mathbf{R}$ & . & . & . & . & C & . & . & $?$ & - & . & $\mathbf{R}$ & 一 & . & . & - & . & . \\
\hline & & B- $28 X-4,85-87$ & + & . & . & . & . & - & . & . & - & F & . & $\mathbf{R}$ & . & . & . & + & $\mathbf{R}$ & . \\
\hline & & B-28X-CC & $\mathrm{F}$ & . & . & . & . & + & . & . & - & $\mathbf{R}$ & . & - & . & . & . & + & . & - \\
\hline & & B- $29 \mathrm{X}-\mathrm{CC}$ & $\mathbf{R}$ & . & . & . & . & - & . & . & - & $\mathbf{R}$ & . & - & . & . & . & $\mathbf{R}$ & $\mathbf{R}$ & . \\
\hline & D. petterssoni & B-30X-CC & $\mathbf{R}$ & . & . & . & . & + & . & . & - & + & . & - & . & . & . & $\mathbf{R}$ & . & . \\
\hline & & B-31X-4, 85-87 & - & . & . & . & . & - & . & 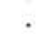 & - & - & . & $\mathbf{R}$ & . & . & . & $\mathbf{R}$ & . & . \\
\hline & & B-31X-CC & - & . & . & . & . & + & . & . & - & $\mathrm{F}$ & . & $\mathbf{R}$ & . & . & . & $\mathbf{R}$ & $\mathbf{R}$ & . \\
\hline & & B- $32 X-4,85-87$ & $\mathrm{C}$ & . & . & . & . & $\mathbf{R}$ & . & . & - & - & . & - & . & . & . & $\mathbf{R}$ & . & . \\
\hline & & B-32X-CC & C & . & . & . & . & - & . & . & - & F & . & F & . & . & . & - & . & . \\
\hline
\end{tabular}


Table 11. Raw data for species associated with upwelling in Holes 722A and 722B. $C=$ common; $F=$ few; $R=R a r e ;+=$ one or two specimens; - = searched for and found to be absent; ? = dubious identification.

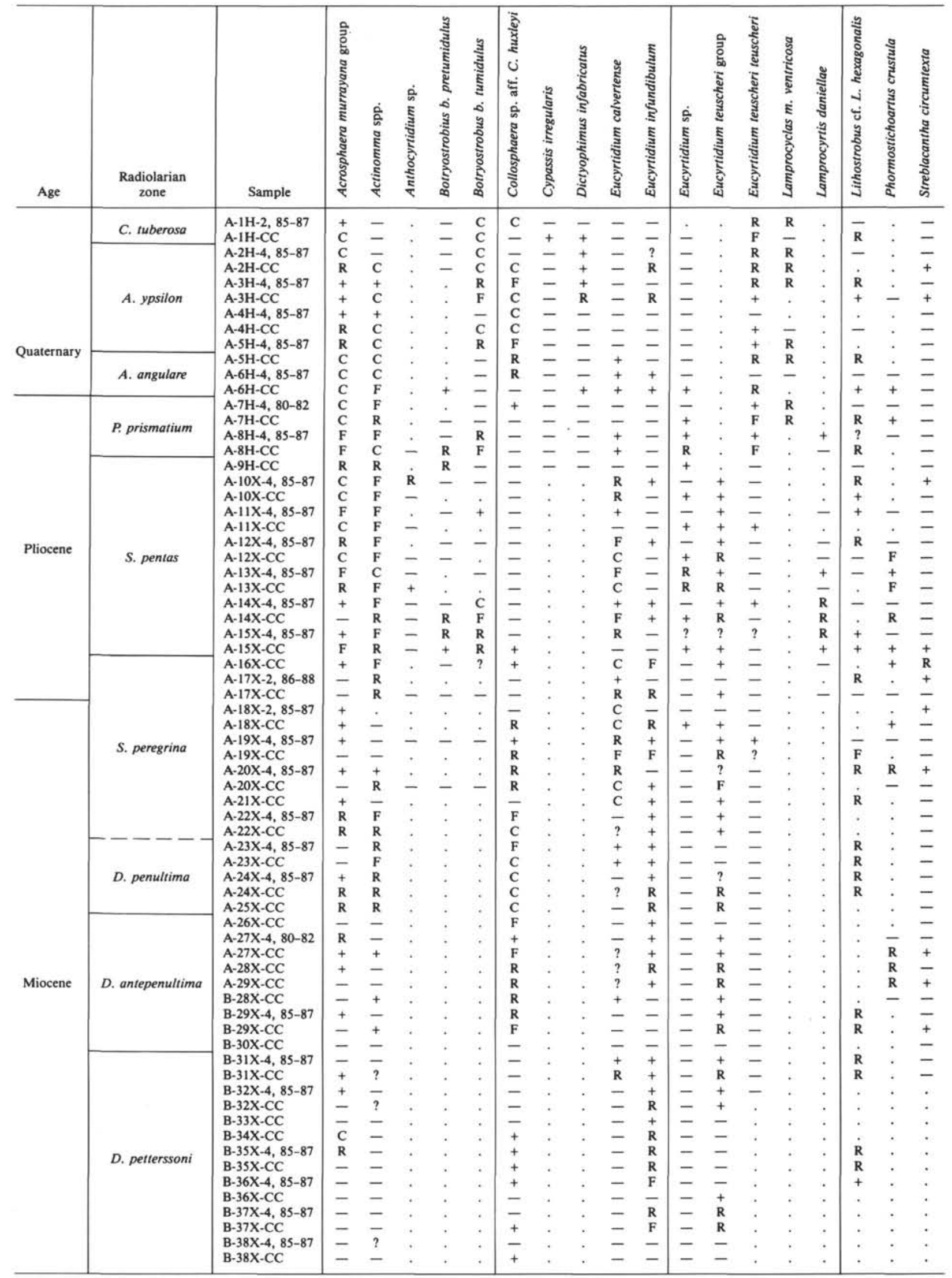


Table 12. Raw data for species associated with upwelling in Hole 731A. $\mathbf{C}=$ common; $\mathbf{F}=\mathbf{f e w}$; $\mathbf{R}=\mathbf{R a r e} ;+=$ one or two specimens; $-=$ searched for and found to be absent; ? = dubious identification.

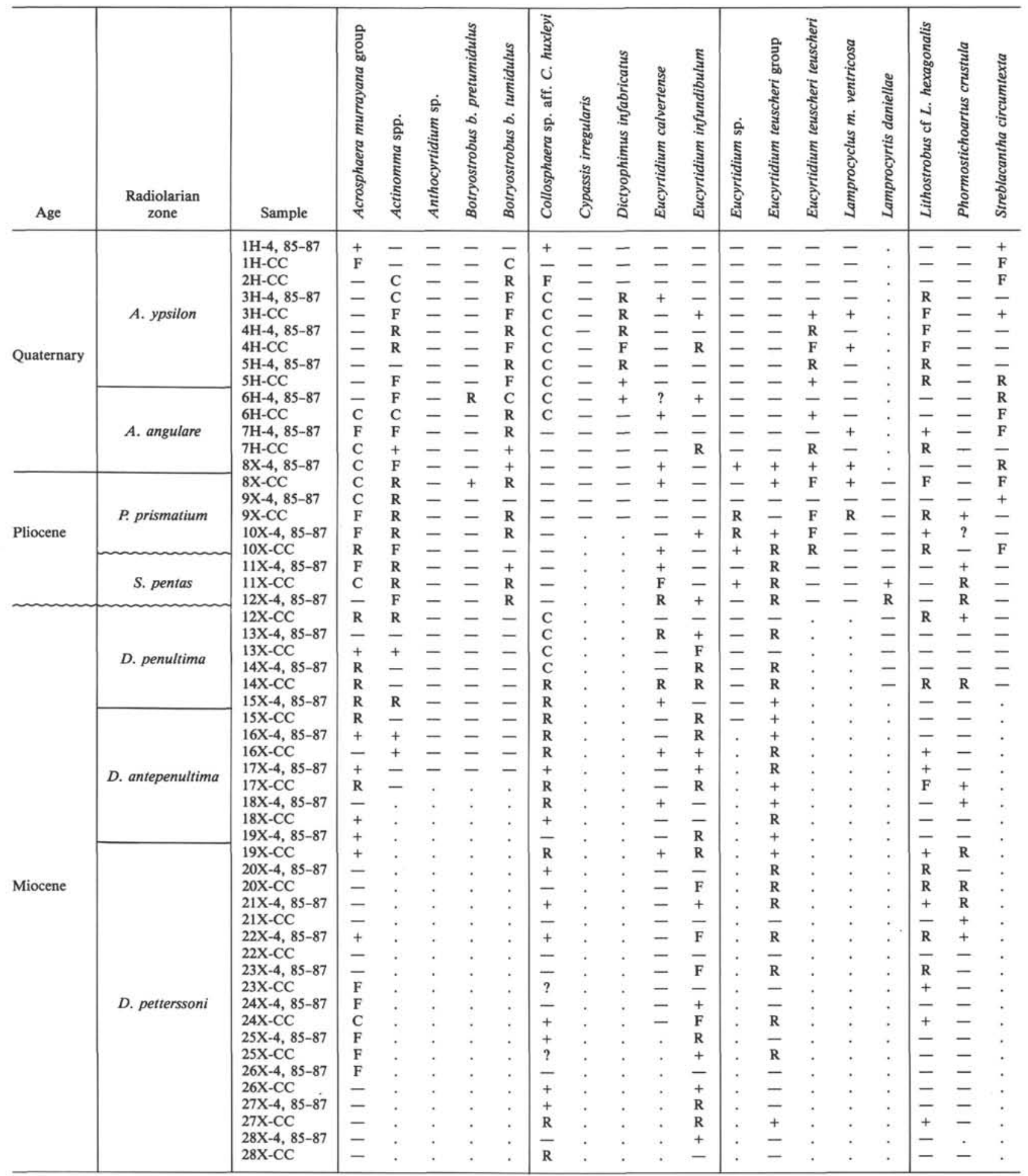


Table 13. List of radiolarian events in Holes 721A and 721B.

\begin{tabular}{|c|c|c|c|c|c|}
\hline RADIOLARIANEVENT & COAE LEVEL & DEPTH $(m)$ & ND. OCEAN AGE (Ma) & SOUACEOFAGE & NOIES \\
\hline B Buccinosphaera invaginata & - & & & & \\
\hline & & & & & \\
\hline T Stylatractus universus & $2 \mathrm{H}-\mathrm{CC} ; 3 \mathrm{H}-\mathrm{CC}$ & $22.25-31.95$ & $0.37-0.47$ & 1 & a \\
\hline B Collosphaera tuberosa & $1 \mathrm{H}-\mathrm{cC} ; 2 \mathrm{H}-4,85-87$ & $12.55-17.90$ & $0.40-0.59$ & 1 & b \\
\hline T Anthocyrtidium nosicaae & $4 \mathrm{H}-4,85-87 ; 4 \mathrm{H}-\mathrm{cc}$ & $37.30-41.65$ & $0.66-0.76$ & 1 & \\
\hline & & & & & \\
\hline T Pterocorys campanula & $4 \mathrm{H}-4,85-87 ; 4 \mathrm{H}-\mathrm{cc}$ & $37.30-41.65$ & $0.66-0.78$ & 1 & \\
\hline B Plerocorys hertwigil & too rare & & $0.76-0.84$ & 1 & \\
\hline$T$ Anthocyrtidium angulare & $4 \mathrm{H}-4,85-87 ; 4 \mathrm{H}-\mathrm{cc}$ & $37.30-41.65$ & $0.94-1.04$ & 1 & \\
\hline B Lamprocyrtis nigrinlae & $4 \mathrm{H}-4,85-87 ; 4 \mathrm{H}-\mathrm{cc}$ & $37.30-41.65$ & $1.02-1.07$ & 1 & \\
\hline & & & & & \\
\hline T Lamprocyrtis neoheteroporos & $4 \mathrm{H}-4,85-87 ; 4 \mathrm{H}-\mathrm{cC}$ & $37.30-41.65$ & $1.09-1.13$ & 1 & \\
\hline B Theocorythlum trachellum & $5 \mathrm{H}-\mathrm{cc} ; 6 \mathrm{H}-4,85-87$ & $51.25-56.60$ & $2.4-2.5$ & 2 & c \\
\hline T Pterocanium prismatium & $5 \mathrm{H}-\mathrm{cc} ; 8 \mathrm{H}-4,85-87$ & $51.25-56.60$ & $1.52-1.56$ & 1 & \\
\hline B Anthocyrtidlum angulare & $5 \mathrm{H}-\mathrm{cc}: 6 \mathrm{H}-4,85-87$ & $5125-5660$ & $1.52-1.64$ & 1 & \\
\hline & & & & & \\
\hline B Cycladophora davisiana & $8 \mathrm{H}-\mathrm{cC} ; 9 \mathrm{H}-4,85-87$ & $79.55-84.90$ & $2.42-2.44$ & 1 & d \\
\hline B Lamprocyrtis neoheteroporos & $8 \mathrm{H}-\mathrm{cc} ; 9 \mathrm{H}-4,85-87$ & $79.55-84.90$ & $2.51-2.53$ & 1 & \\
\hline T Stichocorys peregrina & $9 \mathrm{H}-485-87.9 \mathrm{OH}-\mathrm{cc}$ & $84.90-89.15$ & 262.264 & 1 & \\
\hline & & & & & \\
\hline T Phormostichoartus fistula & B $11 X-c c ; 12 X-c c$ & $105.20-114.80$ & $3.26-3.28$ & 1 & \\
\hline T Spongaster pentas & too rare & & & & \\
\hline & & & & & \\
\hline T Lychnodictyum audax & $11 \mathrm{X}-\mathrm{cc} ; 12 \mathrm{X}-\mathrm{cc}$ & $105.20-114.80$ & $3.33-3.35$ & 1 & \\
\hline T Phormostichoartus doliolum & $13 \mathrm{X}-4,85-87 ; 13 \mathrm{X}-\propto$ & $120,15-124,40$ & $3.53-3.55$ & 1 & \\
\hline & & & & & \\
\hline B Amphirhopalum ypsilon & $13 X-4,85-87 ; 13 X-\infty$ & $120.15-124.40$ & $3.77-3.79$ & 1 & \\
\hline T Spongodiscus ambus & $13 X-4,85-87 ; 13 X-c c$ & $120.15-124.40$ & & & $\theta$ \\
\hline & & & & & \\
\hline B Spongaster tetras tetras & $13 X-c c ; 14 X-4,85-87$ & $124.40-129.75$ & $3.83-3.85$ & 1 & \\
\hline T Sponoodiscus berminahami & ton rare & & & & \\
\hline & too rare & & & & \\
\hline S. berminghami $\rightarrow S$. pentas & too rare & & $4.3-4.4$ & 2 & \\
\hline T Didymocyrtis penultima & $14 X-4,85-87 ; 14 X-c c$ & $129.75-134.10$ & & & \\
\hline & & & & & \\
\hline T Dictyophimus splendens & $16 X-c c ; 17 X-4,75-87$ & $153.50-158.85$ & & & \\
\hline & & & & & \\
\hline T Solenosphaera omnitubus & $16 X-c c ; 17 X-4,85-87$ & $153.50-158.85$ & $4.7-4.8$ & 2 & \\
\hline B Spongaster pentas & too rare & & & & \\
\hline & & & & & \\
\hline T Stichocorys delmontensis & $17 X-c c_{;} ; 18 X-4,85-87$ & $163.20-168.55$ & & & \\
\hline & & 20020200735 & & & \\
\hline T Siphostichartus corona & $21 X-c c ; 22 X-4,85-87$ & $202.22-207.35$ & & & \\
\hline T Botryostrobus bramlettel & $22 X-4,85-87 ; 22 X-c c$ & $207.35-211.70$ & $4.9-5.0$ & 2 & $f$ \\
\hline B Pterocanium prismatium & too rare & & & & \\
\hline & & & & & \\
\hline T Acrobotrys tritubus & $22 X-c c ; 23 X-3,85-87$ & $211.70-215.55$ & $5.3 \cdot 5.4$ & 2 & \\
\hline & & & & & \\
\hline T Stichocorys johnsoni & $23 X-3,85-87 ; 23 X-c c$ & $215.55-216.79$ & $5.7-5.8$ & 2 & 9 \\
\hline$T$ Didymocyrtis antepenultima & $24 X-3,85-87 ; 24 X-c c$ & $225.15-226.56$ & & & \\
\hline & & & & & \\
\hline S. delmontensis $\rightarrow$ S. peregrina & $24 X-c c ; 25 X-4,85-87$ & $226.56-235.85$ & $6.1-6.7$ & 2 & \\
\hline & & & & & \\
\hline B Spongodiscus ambus & $25 X-c c ; 26 X-4,85-87$ & $240.10-245.45$ & & & \\
\hline & & & & & \\
\hline
\end{tabular}


Table 13 (continued).

\begin{tabular}{|c|c|c|c|c|c|}
\hline RADIOLARIANEVENT & CORE LEVE & DEPTH (m) & IND. OCEAN AGE (Ma) & SOUACEOFAGE & NOIES \\
\hline T Calocycletta caepa & 100 rare & & 6.2-6.6 & 2 & h \\
\hline T Phormostichoartus marylandicus & $28 X-4,85-87 ; 28 X-c c$ & $264.95-269.40$ & & & \\
\hline & & & & & \\
\hline T Dendrospyris bursa & $27 X-c c ; 28 X-4,85-87$ & $259.60-264.95$ & $5.0-5.1$ & 2 & c \\
\hline B Solenosphaera omnitubus & $27 X-c c ; 28 X-4,85-87$ & $259.60-264.95$ & $6.3-6.5$ & 2 & \\
\hline B Stlchocorys peregrina & $27 X-c c ; 28 X-4,85-87$ & $259.60-264.95$ & & & \\
\hline & & & & & \\
\hline T Diartus hughesi & $27 X-4,85-87 ; 27 X-c c$ & $255.15-259.60$ & $7.1-7.2$ & 2 & I \\
\hline T Dlctyocoryne ontongensis & too rare & & & & \\
\hline & & & & & \\
\hline B Acrobotrys tritubus & $27 X-c c ; 28 X-4,85-87$ & $259.60-264.95$ & $7.7-7.8$ & 2 & c \\
\hline T Didymocyrtis laticonus & $28 X-4,85-87 ; 28 X-c c$ & $264.95-269.40$ & & & \\
\hline & & & & & \\
\hline B Spongaster berminghami & too rare & & $7.9-8.0$ & 2 & \\
\hline T Diartus petterssoni & $27 X-4,85-87 ; 27 X-c c$ & $255.15-259.60$ & $8.1-8.2$ & 2 & I.1 \\
\hline & & & & & \\
\hline T Botryostrobus miralestensis & $27 X-4,85-87 ; 27 X-\propto c$ & $255.15-259.60$ & $8.1-8.2$ & 2 & $\perp$ \\
\hline B Diartus hughesi & $29 X-c c ; 30 X-c c$ & $279.20-289.00$ & $8.7-8.8$ & 2 & \\
\hline
\end{tabular}

Source of age: 1 = Johnson and Nigrini (1985); 2 = Johnson et al. (1989).

Notes: $\mathrm{a}=$ age from cores MD81-369, $\mathrm{RC14-22}$, and VM 34-35; DSDP 214 probably less accurate; $\mathrm{b}=$ poor data; $\mathrm{c}=$ rare; $\mathrm{d}=$ Theocalyptra davisiana in Johnson and Nigrini (1985); $\mathrm{e}=$ irregular distribution at top of range; $\mathrm{f}=$ datum is too low; $\mathrm{g}=E$. cf. diaphanes in Johnson and Nigrini $(1985) ; \mathrm{h}=$ age from Western Pacific data; $i=$ considerable reworking of this species; $j=$ top at hiatus. 
Table 14. List of radiolarian events in Holes $722 \mathrm{~A}$ and $722 \mathrm{~B}$.

\begin{tabular}{|c|c|c|c|c|c|}
\hline RADIOLARIANEVENT & CORE LEVEL & DEPTH $(m)$ & IND. OCEAN AGE (Ma) & SOUACEOF AGE & NOTES \\
\hline B Buccinosphaera Invaginata & - & & & & \\
\hline & & & & & \\
\hline T Stylatractus universus & - & & & & \\
\hline B Collosphaera tuberosa & A $1 \mathrm{H}-\mathrm{CC} ; 2 \mathrm{H}-4,85-87$ & $9.80-15.15$ & $0.40-0.59$ & 1 & $\mathbf{a}$ \\
\hline & & & & & \\
\hline $\mathrm{T}$ Anthocyrtidium nosicaae & $5 \mathrm{H}-4,85-87 ; 5 \mathrm{H}-\mathrm{cc}$ & $43.95-48.20$ & $0.66-0.76$ & 1 & \\
\hline T Pterocorys campanula & $5 \mathrm{H}-4,85-87 ; 5 \mathrm{H}-\mathrm{cc}$ & $43.95-48.20$ & $0.66-0.78$ & 1 & \\
\hline B Pterocorys hertwigil & $3 \mathrm{H}-4,85-87 ; 3 \mathrm{H}-\mathrm{cc}$ & $24.75-28.00$ & $0.76-0.84$ & 1 & b \\
\hline & & & & & \\
\hline T Anthocyrtidium angulare & $5 \mathrm{H}-4,85-87 ; 5 \mathrm{H}-\mathrm{cc}$ & $43.95-48.20$ & $0.94-1.04$ & 1 & \\
\hline B Lamprocyrtis nigrinlae & $4 \mathrm{H}-\mathrm{cc} ; 5 \mathrm{H}-4,85-87$ & $38.60-43.85$ & $1.02-1.07$ & 1 & \\
\hline T Lamprocyrtis neoheteroporos & $4 \mathrm{H}-\mathrm{cc} ; 5 \mathrm{H}-4,85-87$ & $38.60-43.95$ & $1.09-1.13$ & 1 & \\
\hline & & & & & \\
\hline B Theocorythium trachellum & $5 \mathrm{H}-\mathrm{CC} ; 6 \mathrm{H}-4,85-87$ & $48.20-50.55$ & $2.4-2.5$ & 2 & c \\
\hline T Pterocanium prismatium & $6 \mathrm{H}-4,85-87 ; 6 \mathrm{H}-\mathrm{cc}$ & $53.55-57.50$ & $1.52-1.56$ & 1 & \\
\hline & & & & & \\
\hline B Anthocyrtidium angulare & $6 \mathrm{H}-\mathrm{cC} ; 7 \mathrm{H}-4,80-82$ & $57.50-59.85$ & $1.52-1.64$ & 1 & \\
\hline B Cycladophora davislana & $8 \mathrm{H}-\mathrm{CC} ; \mathrm{9H}-\mathrm{CC}$ & $76.80-86.50$ & $2.42-2.44$ & 1 & d \\
\hline & & & & & \\
\hline B Lamprocyrtis neoheteroporos & $8 \mathrm{H}-\mathrm{CC} ; 9 \mathrm{H}-\mathrm{CC}$ & $76.80-86.50$ & $2.51-2.53$ & 1 & \\
\hline T Stichocorys peregrina & $8 \mathrm{H}-\mathrm{CC} ; \mathrm{OH}-\mathrm{CC}$ & $76.80-86.50$ & $2.62-2.64$ & 1 & \\
\hline & & & & & \\
\hline T Phormostichoartus fistula & $11 X-4,85-87 ; 11 X-c c$ & $101.55-105.90$ & $3.26-3.28$ & 1 & \\
\hline T Spongaster pentas & ton rare & & & & \\
\hline Spongasier pentas & 100 rare & & & & \\
\hline T Lychnodictyum audax & $11 X-4,85-87 ; 11 X-c c$ & $101.55-105.90$ & $3.33-3.35$ & 1 & \\
\hline T Phormostichoartus doliolum & $11 X-c c ; 12 X-4,85-87$ & $105.90-111.25$ & $3.53-3.55$ & 1 & \\
\hline & & & & & \\
\hline B Amphirhopalum ypsilon & $11 X-c c ; 12 X-4,85-87$ & $105.90-111.25$ & $3.77-3.79$ & 1 & \\
\hline B Spongaster tetras tetras & $12 X-c c: 13 X-4,85-87$ & $115,60-120.95$ & $3.83-3.85$ & 1 & \\
\hline & & & & & \\
\hline T Spongaster berminghaml & too rare & & & & \\
\hline & & & & & \\
\hline S. berminghami $\cdots S$. pentas & $12 X-c c ; 13 X-4,85-87$ & $115.60-120.95$ & $4.3-4.4$ & 2 & $\theta$ \\
\hline T Dictyophimus splendens & $13 X-c c ; 14 X-4,85-87$ & $125.30-130.65$ & & & \\
\hline & & & & & \\
\hline T Spongodiscus ambus & $14 X-4,85-87 ; 14 X-c c$ & $130.65-134.90$ & & & \\
\hline & & & & & \\
\hline T Didymocyrtis penultima & $14 X-c c ; 15 X-4,85-87$ & $134.90-140.25$ & & & \\
\hline T Solenosphaera omnitubus & $15 X-c c ; 16 X-c c$ & $144.60-154.30$ & $4.7-4.8$ & 2 & \\
\hline & & & & & \\
\hline B Spongaster pentas & too rare & & & & \\
\hline & & & & & \\
\hline T Botryostrobus bramlettei & $18 X-2,85-87 ; 18 X-c c$ & $166.25-173.60$ & $4.9-5.0$ & 2 & \\
\hline & & & & & \\
\hline B Plerocanium prismatium & 100 rare & & & & \\
\hline T Siphostichartus corona & $19 X-4,85-87 ; 19 X-c c$ & $178.95-183.30$ & & & \\
\hline & & & & & \\
\hline T Stichocorys delmontensis & $19 X-c c ; 20 X-4,85-87$ & $183.30-188.65$ & & & \\
\hline & & & & & \\
\hline T Acrobotrys tritubus & $22 X-4,85-87 ; 22 X-c c$ & $208.05-212.40$ & $5.3-5.4$ & 2 & \\
\hline T Stichocorys johnsonl & $20 X-c c ; 21 X-c c$ & $193.00-202.70$ & $5.7-5.8$ & 2 & $f$ \\
\hline B Spongodiscus ambus & $22 X-4,85-87 ; 2 X-c c$ & $208.05-212.40$ & & & \\
\hline & & & & & \\
\hline T Calocycletta caepa & $24 X-4,85-87 ; 24 X-c c$ & $227.35-231.70$ & $6.2-6.6$ & 2 & g \\
\hline S. delmontensis $\cdots>\mathrm{S}$. peregrina & $22 X-c c ; 23 X-4,85-87$ & $212.40-217.75$ & $6.1 \cdot 6.7$ & 2 & \\
\hline & & & & & \\
\hline
\end{tabular}


Table 14 (continued).

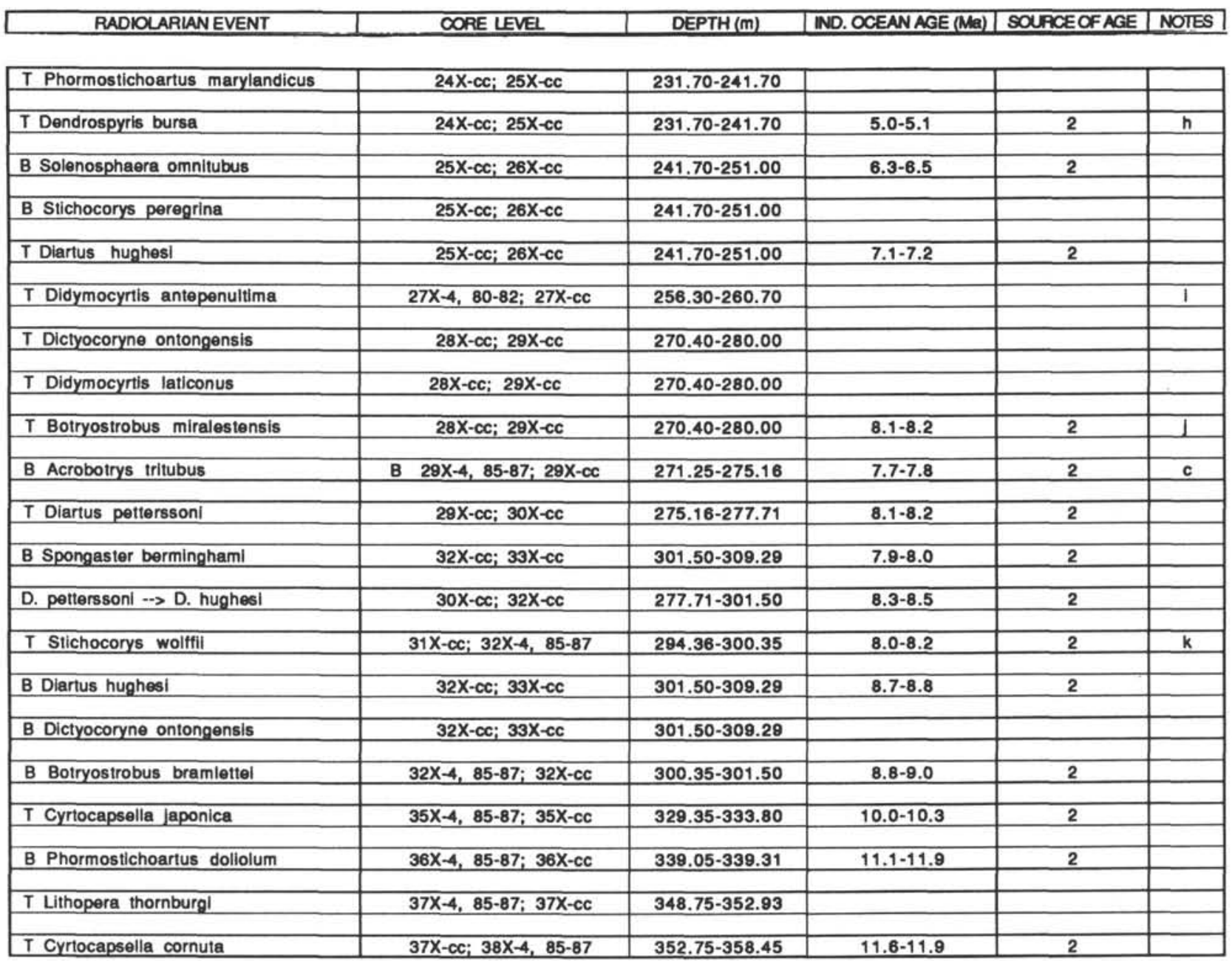

Source of age: 1 = Johnson and Nigrini (1985); 2 = Johnson et al. (1989)

Notes: $\mathrm{a}=$ age from cores MD81-369, RC14-22, and VM 34-35; DSDP 214 probably less accurate; $\mathrm{b}=$ poor data; $\mathrm{c}=$ rare; $\mathrm{d}=$ Theocalyptra davisiana in Johnson and Nigrini (1985); $\mathrm{e}=$ possibly lower?; $\mathrm{f}=E$. cf. diaphanes in Johnson and Nigrini (1985); $\mathrm{g}=$ age from Western Pacific data; $\mathrm{h}=$ rare, published age appears to be incorrect for this area; $i=$ datum is too low; $j=$ irregular distribution at top of range; $k=$ age from Pacific Ocean data. 
Table 15. List of radiolarian events in Hole 728A.

\begin{tabular}{|c|c|c|c|c|c|}
\hline RADIOLARIANEVENT & CORE LEVEI & DEPTH $(m)$ & IND. OCEAN AGE (Ma) & SOAACE OFAGE & NOTES \\
\hline T Stichocorys peregrina & above $\mathrm{gH}-\mathrm{cc}$ & 85.7 & $2.62-2.64$ & 1 & \\
\hline & & & & & \\
\hline T Phormostichoartus fistula & $?$ & & $3.26-3.28$ & 1 & \\
\hline T Spongaster pentas & too rare & & & & \\
\hline & & & & & \\
\hline T Lychnodictyum audax & above $10 X-4,85-87$ & 91.05 & $3.33-3.35$ & 1 & \\
\hline T Phormostichoartus dollolum & $11 X-4,85-87 ; 11 X-c c$ & $100.65-104.90$ & $3.53-3.55$ & 1 & $\mathbf{a}$ \\
\hline B Amphirhopalum ypsilon & $11 X-4,85-87 ; 11 X-c c$ & $100.65-104.90$ & $3.77-3.79$ & 1 & \\
\hline & & & & & \\
\hline B Spongaster tetras & $12 X-c c ; 13 X-4,85-87$ & $114.50-119.85$ & $3.83-3.85$ & 1 & \\
\hline T Spongaster berminghaml & too rare & & & & \\
\hline & & & & & \\
\hline S. berminghaml $\rightarrow$ S. pentas & too rare & & $4.3-4.4$ & 2 & \\
\hline T Spongodiscus ambus & $15 X-4,85-87 ; 15 X-c c$ & $139.25-143.50$ & & & b \\
\hline & & & & & \\
\hline T Didymocyrtis penultima & $16 X-4,85-87 ; 16 X-c c$ & $148.85-153.10$ & & & \\
\hline T Solenosphaera omnitubus & $23 X-c c: 24 X-4,85-87$ & $220.80-226.15$ & $4.7-4.8$ & 2 & c \\
\hline & & & & & \\
\hline B Spongaster pentas & too rare & & & & \\
\hline & & & & & \\
\hline T Botryostrobus bramlettel & $?$ & & $4.9-5.0$ & 2 & \\
\hline & & & & & \\
\hline B Pterocanium prismatium & 100 rare & & & & \\
\hline T Didymocyrtis antepenultima & $?$ & & & & \\
\hline & & & & & \\
\hline T Stichocorys delmontensis & $26 X-4,85-87 ; 26 X-c c$ & $245.45-249.80$ & & & \\
\hline T Siphostichartus corona & $26 X-4,85-87: 26 X-c c$ & $245.45-249.80$ & & & \\
\hline & & & & & \\
\hline T Acrobotrys tritubus & 100 rare & & $5.3-5.4$ & 2 & \\
\hline & & & & & \\
\hline B Spongodiscus ambus & $30 X-c c ; 31 X-4,85-87$ & $288.50-293.82$ & & & \\
\hline T Stichocorys johnsoni & $29 X-c c ; 30 X-4,85-87$ & $278.80-284.15$ & $5.7-5.8$ & 2 & d \\
\hline & & & & & \\
\hline T Calocycletta caepa & $32 X-4,85-87 ; 32 X-c c$ & $303.45-307.80$ & $6.2-6.6$ & 2 & $\theta$ \\
\hline S. delmontensis $\rightarrow S$. peregrina & $31 X-c c ; 32 X-c c$ & $298.10-307.80$ & 6.1-6.7 & 2 & \\
\hline & & & & & \\
\hline T Phormostichoartus marylandicus & $?$ & & & & \\
\hline T Dendrospyris bursa & too rare & & $5.0-5.1$ & 2 & \\
\hline & & & & & \\
\hline B Solenosphaera omnitubus & $33 X-c c ; 34 X-4,85-87$ & $317.50-322.85$ & $6.3-6.5$ & 2 & \\
\hline B Stichocorys peregrina & $34 X-4,85-87 ; 33 X-c c$ & $313.15-317.50$ & & & \\
\hline & & & & & \\
\hline T Diartus hughesi & $34 X-4,85-87 ; 34 X-c c$ & $322.85-327.20$ & $7.1-7.2$ & 2 & \\
\hline$T$ Didymocyrtis laticonus & $36 X-4,85-87 ; 36 X-c c$ & $342,15-346,40$ & & & \\
\hline & & & & & \\
\hline$T$ Botryocyrtis miralestensis & $36 X-4,85-87 ; 36 X-c c$ & $342.15-346.40$ & $8.1-8.2$ & 2 & $f$ \\
\hline
\end{tabular}

Source of age: 1 = Johnson and Nigrini (1985); 2 = Johnson et al. (1989).

Notes: $\mathrm{a}=$ datum is too low; $\mathrm{b}=$ ?reworking or $\mathrm{T}$ may be between $11 \mathrm{X}-4$ and $11 \mathrm{X}-\mathrm{CC} ; \mathrm{c}=$ datum may be higher, see Appendix $\mathrm{A}, \mathrm{Table} 7 ; \mathrm{d}=E$. cf. diaphanes in Johnson and Nigrini (1985); $\mathrm{e}=$ age from Western Pacific data; $\mathrm{f}=$ may be reworked. 
Table 16. List of radiolarian events in Hole 730A.

\begin{tabular}{|c|c|c|c|c|c|}
\hline RADIOLARIAN EVENT & CORE LEVEL & DEPTH $(m)$ & ND. OCEAN AGE (Ma) & SOUACEOFAGE & NOTES \\
\hline T Stichocorys wolffil & $8 X-4,85-87 ; 8 X-c c$ & $70.85-75.20$ & $8.0-8.2$ & 2 & a \\
\hline T Cyrtocapsella Japonica & $10 \mathrm{X}-\mathrm{cc} ; 11 \mathrm{X}-4,85-87$ & $94.60-99.95$ & $10.0-10.3$ & 2 & \\
\hline B Diartus petterssoni & $18 X-4,85-87 ; 18 X-c$ & $167.55-171.90$ & $10.6-10.8$ & & $\mathbf{b}$ \\
\hline & & & & & \\
\hline B Phormostichoartus doliolum & too rare & & $11.1-11.9$ & 2 & \\
\hline$T$ Lithopera thornburgl & $16 X-c c ; 17 X-4,85-87$ & $152.60-157.95$ & & & \\
\hline T Cyrtocapsella cornuta & $17 X-4,85-87: 17 X-\propto$ & $157.95-162.20$ & $11.6-11.9$ & 2 & \\
\hline & & & & & \\
\hline T Lithopera renzae & $19 X-4,85-87 ; 19 X-\infty c$ & $177.25-181.60$ & $12.1-12.3$ & 2 & c \\
\hline
\end{tabular}

Source of age: 2 = Johnson et al. (1989).

Notes: $\mathrm{a}=$ age from Pacific Ocean data; $\mathrm{b}=$ datum is low, closer to Pacific Ocean age; $\mathrm{c}=$ age from Western Pacific data. 
Table 17. List of radiolarian events in Hole 731A.

\begin{tabular}{|c|c|c|c|c|c|}
\hline RADIOLARIANEVENT & CORE LEVEI & DEPTH $(m)$ & IND. OCEAN AGE (Ma) & SQUACEOF AGE & NOTES \\
\hline B Buccinosphaera invaginata & - & & & & \\
\hline & & & & & \\
\hline T Stylatractus unlversus & $1 \mathrm{H}-\mathrm{CC} ; 2 \mathrm{H}-\mathrm{CC}$ & $9.80-19.30$ & $0.37-0.47$ & 1 & $\mathbf{a}$ \\
\hline B Collosphaera tuberosa & - & & $0.40-0.59$ & 1 & \\
\hline T Anthocyrtidium nosicaae & $3 \mathrm{H}-4 ; 85-87 ; 3 \mathrm{H}-\mathrm{cc}$ & $24.65-28.80$ & $0.66-0.76$ & 1 & \\
\hline T Pterocorys campanula & $3 \mathrm{H}-\mathrm{cc}: 4 \mathrm{H}-4,85-87$ & $28.80-34,15$ & $0.66-0.78$ & 1 & \\
\hline & & & & & \\
\hline B Pterocorys hertwigil & $4 \mathrm{H}-4 ; 85-87 ; 4 \mathrm{H}-\mathrm{CC}$ & $34.15-38.30$ & $0.76-0.84$ & 1 & \\
\hline T Anthocyrtidium angulare & $5 \mathrm{H}-\mathrm{cc} ; 6 \mathrm{H}-4,, 85-87$ & $47.80-53.15$ & $0.94-1.04$ & 1 & \\
\hline & & & & & \\
\hline B Lamprocyrtis nigrinlae & $5 \mathrm{H}-\mathrm{CC} ; 6 \mathrm{H}-4, \ldots 85-87$ & $47.80-53.15$ & $1.02-1.07$ & 1 & \\
\hline T Lamprocyrtis neoheteroporos & $5 \mathrm{H}-\mathrm{cc} ; 6 \mathrm{H}-4,85-87$ & $47.80-53.15$ & $1.09-1.13$ & 1 & \\
\hline & & & & & \\
\hline B Theocorythlum trachellum & $7 \mathrm{H}-\mathrm{CC} ; 8 X-4,85-87$ & $67.00-72.35$ & $2.4-2.5$ & 2 & b \\
\hline T Pterocanium prismatium & $8 X-4,85-87 ; 8 X-c c$ & $72.35-76.70$ & $1.52-1.56$ & 1 & b \\
\hline & & & & & \\
\hline B Anthocyrtidium angulare & $7 \mathrm{H}-c c ; 8 X-4,85-87$ & $67.00-72.35$ & $1.52-1.64$ & 1 & \\
\hline B Cycladophora davisiana & $10 X-\infty ; 1 X-4,85-87$ & $96.00-101.35$ & $2.42-2.44$ & 1 & c \\
\hline B Lamprocyrtis neoheteroporos & $10 X-c c ; 11 X-4,85-87$ & $96.00-101.35$ & $2.51-2.53$ & 1 & \\
\hline & & & & & \\
\hline T Stichocorys peregrina & $10 X-\infty ; 11 X-4,85-87$ & $96.00-101.35$ & $2.62-2.64$ & 1 & \\
\hline T Phormostichoartus fistula & $9 X-4,85-87 ; 9 X-c c$ & $82.05-86.40$ & $3.26-3.28$ & 1 & $d$ \\
\hline T Sponoaster pentas & & & & & \\
\hline T Spongaster pentas & 100 rare & & & & \\
\hline T Lychnodictyum audax & $10 X-c c ; 11 X-4,85-87$ & $96.00-101.35$ & $3.33-3.35$ & 1 & \\
\hline T Phormostichoartus dollolum & $10 X-c ;: 11 X-4,85-87$ & $96.00-101.35$ & $3.53-3.55$ & 1 & \\
\hline B Amphirhopalum yosilon & $10 \times-c \cdot 11 \times-485-87$ & $9600-101.35$ & $377-379$ & 1 & \\
\hline & & & & & \\
\hline B Spongaster tetras tetras & $11 X-c c ; 12 X-4,85-87$ & $105.70-111.05$ & 3.83-3.85 & 1 & \\
\hline T Spongaster berminghami & $11 X-c c ; 12 X-4,85-87$ & $105.70-111.05$ & & & \\
\hline & & & & & \\
\hline S. berminghaml $\rightarrow S$. pentas & too rare & & $4.3-4.4$ & 2 & \\
\hline & & & & & \\
\hline T Spongodiscus ambus & $11 X-4,85-87 ; 11 X-c$ & $101.35-105.70$ & & & \\
\hline T Didymocyrtis penultima & $11 X-c c ; 12 X-4,85-87$ & $105.70-111.05$ & & & \\
\hline & & & & & \\
\hline T Solenosphaera omnitubus & $12 X-4,85-87 ; 12 X-c c$ & $111.05-115.40$ & $4.7-4.8$ & 2 & \\
\hline T Dictyophimus splendens & $12 X-4,85-87 ; 12 X-c c$ & $111.05-115,40$ & & & \\
\hline & & & & & \\
\hline B Spongaster pentas & too rare & & & & \\
\hline & & & & & \\
\hline T Botryostrobus bramlettei & $13 X-c c ; 14 X-4,85-87$ & $125.00-130.35$ & $4.9-5.0$ & 2 & \\
\hline B Prerocanium prismatium & too rare & & & & \\
\hline & & & & & \\
\hline T Didymocyrtis antepenultima & $14 X-4,85-87 ; 14 X-c c$ & $130.35-134.70$ & & & \\
\hline & & & & & \\
\hline T Stichocorys delmontensis & $12 X-4,85-87 ; 12 X-c c$ & $111.05-115.40$ & & & \\
\hline T Siphostichartus corong & $12 X-4,85-87 ; 12 X-c c$ & $111005-115,40$ & & & \\
\hline & & & & & \\
\hline T Acrobotrys tritubus & $12 X-c c ; 13 X-4,85-87$ & $115.40-120.70$ & 5.3-5.4 & 2 & \\
\hline & & & & & \\
\hline T Stichocorys johnsoni & $12 \mathrm{X}-4,85-87 ; 12 \mathrm{X}-\mathrm{cc}$ & $111.05-115.40$ & $5.7-5.8$ & 2 & $\theta$ \\
\hline B Spongodiscus ambus & $12 X-c c ; 13 X-4,85-87$ & $115.40-120.70$ & & & \\
\hline & & & & & \\
\hline T Calocycletta caepa & $13 X-4,85-87 ; 13 X-c c$ & $120.70-125.00$ & $6.2-6.6$ & 2 & $f$ \\
\hline & & & & & \\
\hline
\end{tabular}


Table 17 (continued).

\begin{tabular}{|c|c|c|c|c|c|}
\hline RADIOLARIANEVENT & CORE LEVEI & DEPTH (m) & IND. OCEAN AGE (Ma) & SOUACE OF AGE & NOTES \\
\hline S. delmontensis $\rightarrow S$. peregrina & $12 X-c c ; 13 X-c c$ & $115.40 \cdot 125.00$ & $6.1-6.7$ & 2 & \\
\hline T Phormostichoartus marylandicus & $?$ & & & & \\
\hline T Dendrospyris bursa & $13 X-c c: 14 X-4,85-87$ & $125.00-130.35$ & $50-5.1$ & 2 & \\
\hline & & & & & \\
\hline T Didymocyrtis antepenultima & $13 X-c c ; 14 X-4,85-87$ & $125.00-130.35$ & & & \\
\hline B Solenosphaera omnitubus & $14 X-4,85-87 ; 14 X-c c$ & $130.35-134.70$ & $6.3-6.5$ & 2 & \\
\hline B Stlchocorys peregrina & $13 X-c c ; 14 X-4,85-87$ & $125.00-130.35$ & & & \\
\hline & & & & & \\
\hline T Dlartus hughesl & $15 X-4,85-87 ; 15 X-c c$ & $140.85-144.40$ & $7.1-7.2$ & 2 & \\
\hline T Dictyocoryne ontongensis & $16 X-4,85-87 ; 16 X-c c$ & $149.75-154.00$ & & & \\
\hline & & & & & \\
\hline B Acrobotrys tritubus & $16 X-4,85-87 ; 16 X-\propto$ & $149.75-154.00$ & 7.7-7.8 & 2 & b \\
\hline T Botryostrobus miralesiensis & $18 X-4,85-87 ; 18 X-c c$ & $169.05-173.40$ & $8.1-8.2$ & 2 & \\
\hline & & & & & \\
\hline T Diartus petterssoni & $18 X-C C ; 19 X-4,85-87$ & $173.40-178.75$ & $8.1-8.2$ & 2 & \\
\hline T Didymocyrtis laticonus & $19 X-4,85-87 ; 19 X-c c$ & $178.75-183.10$ & & & \\
\hline & & & & & \\
\hline B Spongaster berminghami & $20 X-c c ; 21 X-4,85-87$ & $192.80-198.15$ & $7.9-8.0$ & 2 & \\
\hline D. petterssoni $\rightarrow$ D. hughesi & $19 X-4,85-87 ; 21 X-4,85-87$ & $178.75-198.15$ & $8.3-8.5$ & 2 & \\
\hline B Dlartus huahesi & $21 X-4 \quad 85-87 \cdot 21 X-\propto$ & $198.15-20250$ & $8.7-8.8$ & 2 & \\
\hline & & & & & \\
\hline T Stichocorys wolffil & $20 X-4,85-87 ; 20 X-c c$ & $188.45-192.80$ & $8.0-8.2$ & & $\mathrm{~h}$ \\
\hline B Dictyocoryne ontongensis & $21 X-4,85-87 ; 21 X-c c$ & $198.15-202.50$ & & & \\
\hline & & & & & \\
\hline B Botryostrobus bramlettei & $20 X-c c ; 21 X-4,85-87$ & $192.80-198.15$ & $8.8-9.0$ & 2 & \\
\hline T Cyrtocapsella japonica & $24 X-4,85-87 ; 24 X-c c$ & $227.25-231.60$ & $10.0-10.3$ & 2 & \\
\hline & & & & & \\
\hline T Lithopera thornburgl & $27 X-4,85-87 ; 27 X-c c$ & $256.27-260.60$ & & & \\
\hline T Cyrtocapsella cornuta & $27 X-C C ; 28 X-4,85-87$ & $260.60-265.96$ & $11.6-11.9$ & 2 & \\
\hline
\end{tabular}

Source of age: 1 = Johnson and Nigrini (1985); 2 = Johnson et al. (1989).

Notes: $\mathrm{a}=$ age from cores MD81-369, RC14-22 and VM 34-35, DSDP 214 probably less accurate; $\mathrm{b}=\mathrm{rare} ; \mathrm{c}=$ Theocalyptra davisiana in Johnson and Nigrini (1985); $\mathrm{d}=$ datum too high, possible reworking; $\mathrm{e}=E$. cf. diaphanes in Johnson and Nigrini (1985); $\mathrm{f}=$ age from Western Pacific data; $\mathrm{g}=$ published age appears to be incorrect for this area; $\mathrm{h}=$ age from Pacific Ocean data. 


\section{NIGRINI}
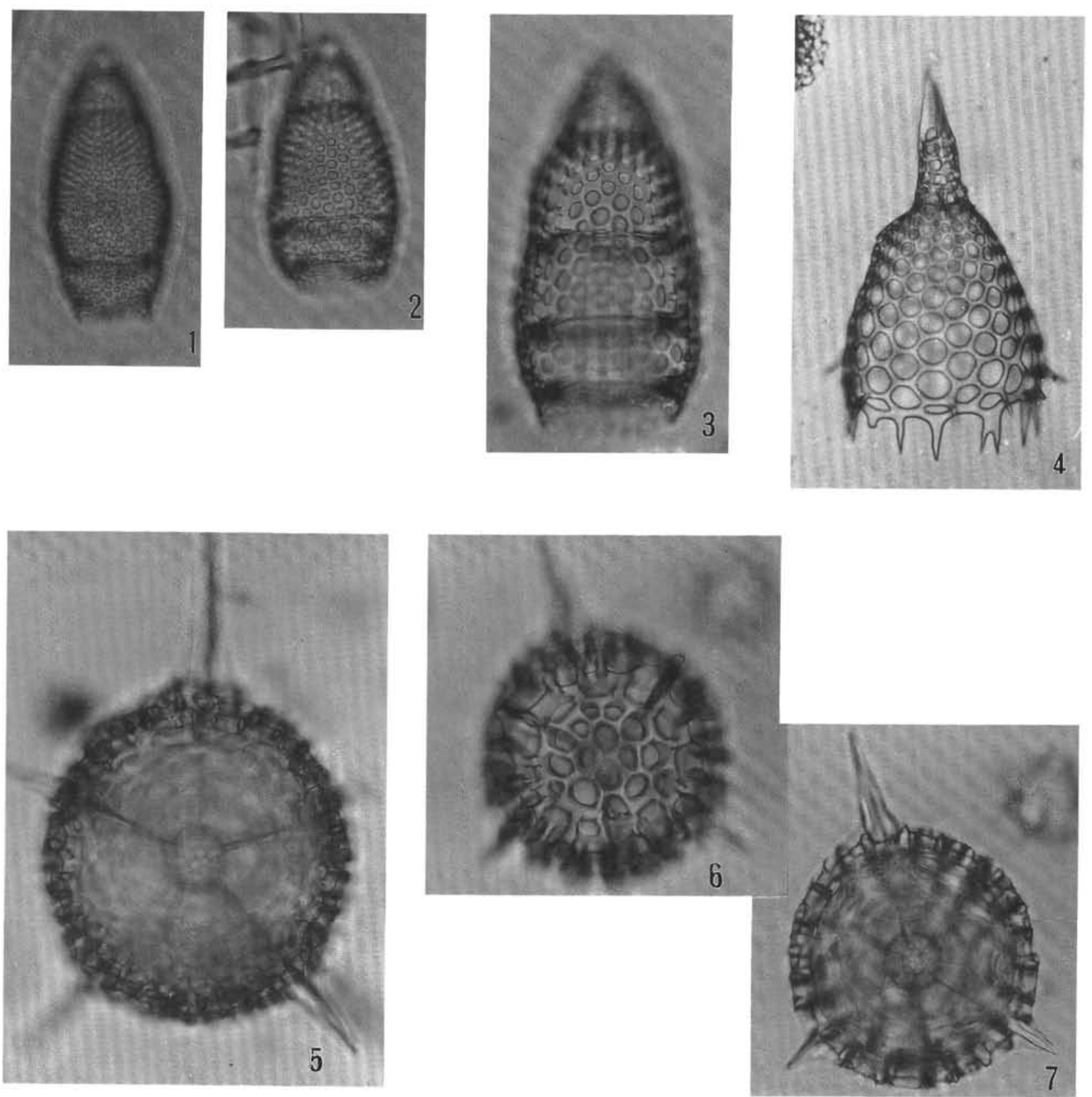

Plate 1. 1. Eucyrtidium sp. with irregular pores, 117-721B-10X-CC, M46/0; $\times 270$. 2. Eucyrtidium sp. with regular pores, 117-722A-15X-CC, $\mathrm{V} 17 / 1 ; \times 270$. 3. Eucyrtidium calvertense, $117-722 \mathrm{~A}-12 \mathrm{X}-4, \mathrm{R} 43 / 0 ; \times 270$. 4. Anthocyrtidium sp., 117-721B-10X-CC, Q44/2; $\times 270$. 5. Actinomma spp., 117-722A-8H, B-O15/3; $\times 150$. 6. Actinomma spp. focused on cortical shell, $117-721 \mathrm{~B}-24 \mathrm{X}-3, \mathrm{~A}-\mathrm{T} 16 / 4 ; \times 150$. 7. Actinomma spp. focused on medullary shell, 117-721B-24X-3, A-T16/4; $\times 150$. 